6-1993

\title{
The Marshall Lambert Symposium Contributions and Road Log
}

Joseph A. Hartman

University of North Dakota, joseph.hartman@und.edu

Allen J. Kihm

How does access to this work benefit you? Let us know!

Follow this and additional works at: https://commons.und.edu/gge-fac

\section{Recommended Citation}

Joseph A. Hartman and Allen J. Kihm. "The Marshall Lambert Symposium Contributions and Road Log" (1993). Geology and Geological Engineering Faculty Publications. 5.

https://commons.und.edu/gge-fac/5

This Conference Proceeding is brought to you for free and open access by the Department of Geology and Geological Engineering at UND Scholarly Commons. It has been accepted for inclusion in Geology and Geological Engineering Faculty Publications by an authorized administrator of UND Scholarly Commons. For more information, please contact und.commons@library.und.edu. 


\title{
The Marshall Lambert Symposium
}

\author{
SPONSORED BY THE \\ Pioneer Traills Museum \\ BOWMAN, NORTH DAKOTA
}

Symposium, Banquet, and Field Trip

June 19 \& 20, 1993

Published by the

North Dakota Geological Society

P.O. Box 82

Bismarck, ND 58502-0082

1993 


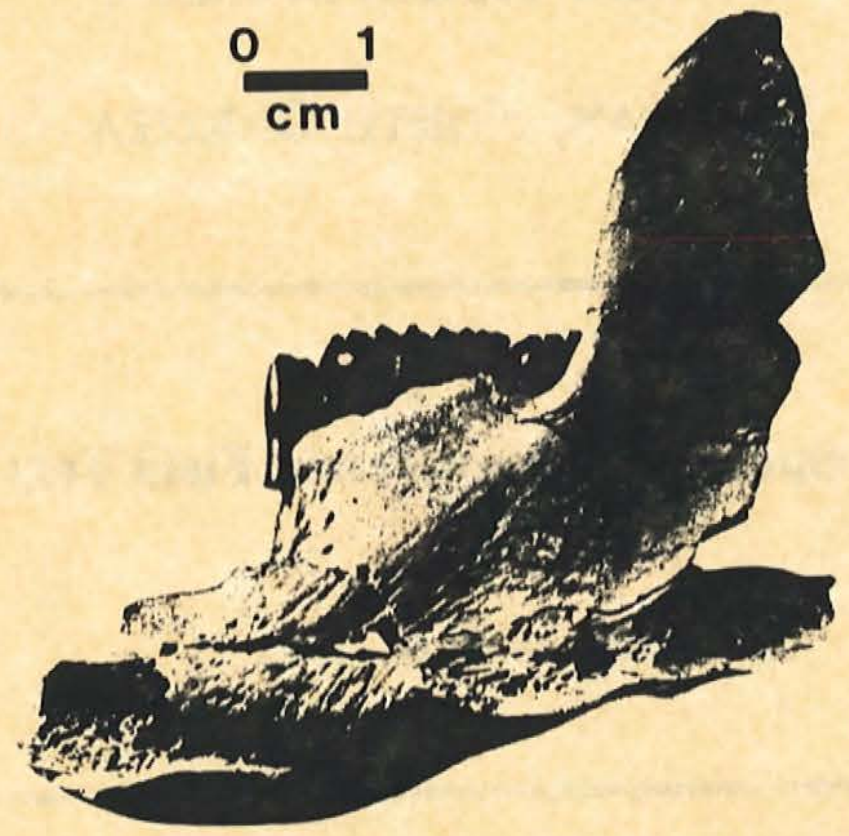

Taeniolabis lamberti Simmons

Paleocene multituberculate from the Ludlow Formation.

Labial view of right dentary of holotype.

Collected by Marshall Lambert at the Bechtold Locality,

Carter County, Montana.

(N.B. Simmons, 1987, Journal of Paleontology, v. 61, p. 801)

Reproduced by permission of the Paleontological Society. 


\section{The MARShall LAMbert SyMposium}

SPONSORED BY THE

\section{Pioneer Trails Museum, Bowman, North Dakota}

June $19 \& 20,1993$

\section{PROGRAM OF EVENTS}

Saturday, June 19

Agenda - Symposium and Banquet

Sunday, June 20

Agenda - Field Trip

UPPER CRETACeOUS AND LoWer Tertiary Geology AND

PALEONTOLOGY OF EXTREME SOUTHWESTERN NORTH DAKOTA

Jointly Sponsored by the

North Dakota Geological Society and the

Pioneer Trails Museum

\section{Symposium and Field Trip Coordinator}

Dean A. Pearson

Pioneer Trails Museum

Symposium and Field Trip Road Log Editors

Allen J. Kihm

Department of Earth Science

Minot State University

Minot, North Dakota

(701) $857-3864$
Joseph H. Hartman

Energy \& Environmental Research Center

University of North Dakota

Grand Forks, North Dakota

(701) $777-5000$ 


\section{The MARSHALL LAMBERT SyMPOSIUM}

Pioneer Trails Museum, Bowman, North Dakota

June $19 \& 20,1993$

\section{"OUR ThaNKS Go To"}

The coordinators and editors of the Marshall Lambert Symposium, Banquet, and Field Trip wish to extend special thanks to the many individuals and sponsors who provided their time, effort, resources, and financial support to this undertaking, with grateful appreciation to the following:

Members of the Pioneer Trails Museum

North Dakota Geological Society

Energy \& Environmental Research Center

University of North Dakota

City of Bowman

Bowman County Historical and Genealogical Society 


\section{The Marshall Lambert Symposium}

\section{TABLE OF CONTENTS}

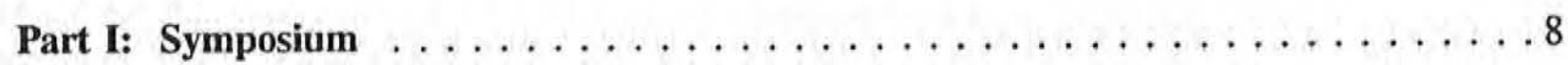

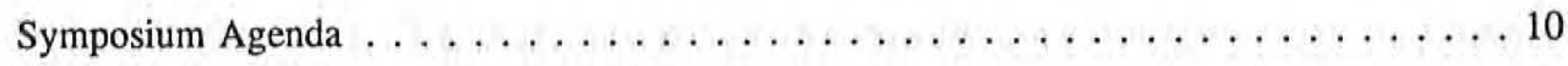

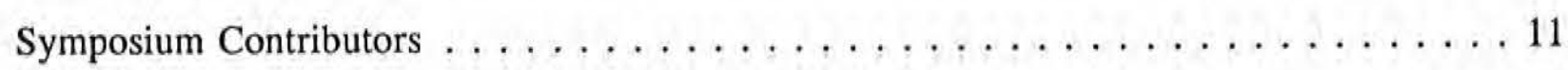

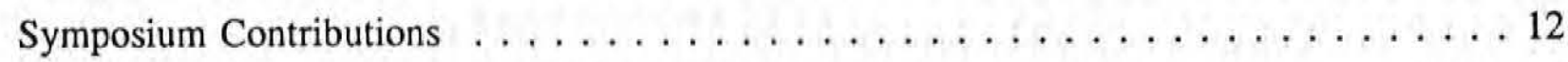

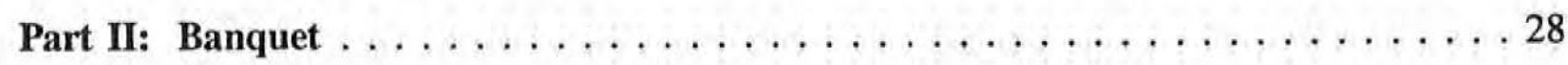

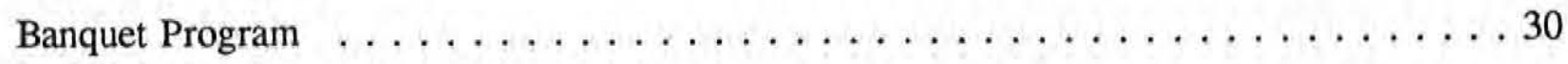

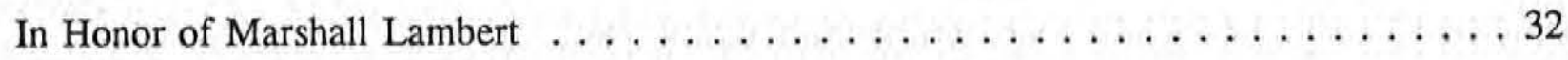

Society of Vertebrate Paleontology Resolution . . . . . . . . . . . . . 34

Part III: Field Trip and $\operatorname{Road} \log \ldots \ldots \ldots \ldots \ldots \ldots \ldots \ldots \ldots \ldots \ldots \ldots \ldots \ldots$

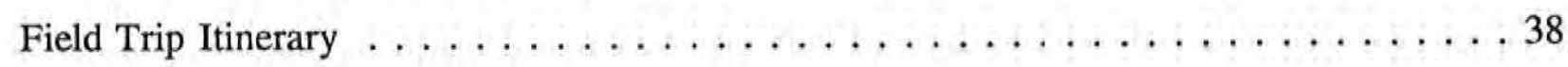

Road $\log$ Contents $\ldots \ldots \ldots \ldots \ldots \ldots \ldots \ldots \ldots \ldots \ldots \ldots \ldots \ldots \ldots \ldots \ldots \ldots \ldots \ldots$

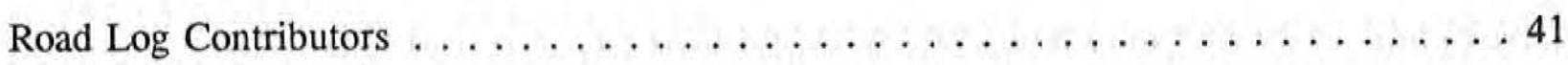

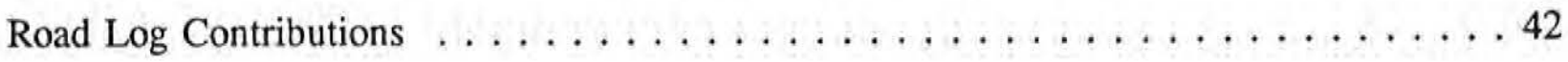


The Marshall LAMBERT SyMposium

\section{Part I:}

\section{SYMPOSIUM}

-8 - 



\title{
SYMPOSIUM AGENDA
}

\author{
Moderators - Allen J. Kihm and Joseph H. Hartman
}

9:00 Les Snavely, Director of the Pioneer Trails Museum Introduction and welcome.

9:15 F.D. Holland, Jr. First aid to dinosaurs from Marshall Lambert.

9:45 Brian J. Witzke and Raymond R. Anderson The terminal Cretaceous Manson impact structure of Iowa and its possible influence on $K / T$ events in the Western Interior.

10:15 Barbara D. Wehrfritz Silcrete: A distinctive rock type related to $\mathrm{K} / \mathrm{T}$ boundary events.

10:45 Edward S. Belt, Tekla Harms, Edward C. Beutner, W. Coppinger, and John A.

Diemer

Some implications of changes in paleodrainage directions below and above an unconformity within the Paleocene Tongue River sandstones, near Ekalaka, southeastern Montana.

11:15 Edward C. Murphy, John W. Hoganson, and Nels F. Forsman The stratigraphy and paleontology of the Chadron, Brule, and Arikaree Formations in North Dakota.

11:45 LUNCH BREAK (11:45-1:30)

1:30 Kirk R. Johnson The Late Cretaceous (Maastrichtian) flora of the Hell Creek Formation in southwestern North Dakota.

2:00 Joseph H. Hartman

An unusual occurrence of Paleocene nonmarine mollusks on the east flank of the Cedar Creek Anticline, Fallon County, Montana.

2:30 Kenneth Carpenter Did pachycephalosaurs (Ornithischia: Dinosauria) really butt heads?

3:00 Dean A. Pearson

The Medicine Pole Hills Local Fauna - The first diverse Chadronian (latest Eocene)-age fauna from North Dakota.

3:30 Allen J. Kihm

Late Paleocene mammalian biochronology of the Fort Union Group, North Dakota: Plesiadapis (Plesiadapiformes) from the Brisbane, Judson, and Wannagan Creek Quarry Local Faunas.

\section{4:00 CLOSING COMMENTS AND ADJOURNMENT}

5:30 SOCIAL HOUR - Pioneer Trails Museum

7:00 BANQUET - City Hall 


\section{The MARShall LAMBERT SyMPOSIUM}

\section{SYMPOSIUM CONTRIBUTORS}

\section{* Presenters}

\section{Raymond R. Anderson}

Iowa Department of Natural Resources, Geological Survey Bureau, 123 North Capitol Street, lowa City, Iowa 52242

\section{Edward S. Belt*}

Amherst College, Department of Geology, P.O. Box 5000, Amherst, Massachusetts 01002

\section{Edward C. Beutner}

Franklin and Marshall College, Department of Geology, Lancaster, Pennsylvania 17604

Kenneth Carpenter*

Denver Museum of Natural History, Department of Earth Sciences, 2001 Colorado Boulevard, Denver, Colorado 80205

Walter Coppinger

Trinity University, Geology Department, San Antonio, Texas 78212

\section{John A. Diemer}

University of North Carolina at Charlotte, Department of Geography and Earth Sciences, Charlotte, North Carolina 28223

Nels F. Forsman

University of North Dakota, Department of Geology and Geological Engineering, P.O. Box 8068, Grand Forks, North Dakota 58202

Kirk R. Johnson*

Denver Museum of Natural History, Department of Earth Sciences, 2001 Colorado Boulevard, Denver, Colorado 80205

Tekla Harms

Amherst College, Department of Geology, P.O. Box 5000, Amherst, Massachusetts 01002

Joseph H. Hartman*

Energy \& Environmental Research Center, P.O. Box 9018, Grand Forks, North Dakota 58202

John W. Hoganson*

North Dakota Geological Survey, 600 East Boulevard Avenue, Bismarck, North Dakota 58505

Frank D. Holland, Jr.*

University of North Dakota, Department of Geology and Geological Engineering, P.O. Box 8068, Grand Forks, North Dakota 58202

Allen J. Kihm*

Minot State University, Department of Earth Science, 500 University Avenue West, Minot, North Dakota 58702

Edward C. Murphy*

North Dakota Geological Survey, 600 East Boulevard Avenue, Bismarck, North Dakota 58505

Dean A. Pearson*

Pioneer Trails Museum, Department of Paleontology, 100 East 2nd Street, P.O. Box 1044, Bowman, North

Dakota 58623

Les Snavely

Pioneer Trails Museum, 100 East 2nd Street, P.O. Box 1044, Bowman, North Dakota 58623

Barbara D. Wehrfritz*

Consulting Geologist, 1820 Wyoming Avenue, Meeteetse, Wyoming 82433

Brian J. Witzke*

Iowa Department of Natural Resources, Geological Survey Bureau, 123 North Capitol Street, Iowa City, lowa 52242 


\title{
CONTRibutions to The MARShall LAMBERT SyMposium
}

\section{FIRST AID TO DINOSAURS FROM MARSHALL LAMBERT}

\author{
F.D. Holland, Jr., Professor Emeritus \\ Department of Geology and Geological Engineering, \\ University of North Dakota, Grand Forks, ND 58202-8358
}

While Marshall Lambert was never successful in reviving a dinosaur, it is no exaggeration to say that his enthusiasm, care, persistence, and skill in administering them first aid is known from coast to coast. He has willingly and unstintingly shared his knowledge and skill with any who have asked for help. Marshall's aid was central to the collection and preservation of a fine skull of Triceratops for the University of North Dakota (UND). The specimen was found by Charles I. Frye late in the field season of 1963, while tracing strata of the Upper Cretaceous Hell Creek Formation, as part of his UND doctoral dissertation studies. The skull was found $12.2 \mathrm{~m}(40 \mathrm{ft}$ ) below the Paleocene Tullock Formation, representing the Ludlow Formation of current North Dakota Geological Survey usage. The fossil came from a southwest exposure, west of the road (NW1/4 NE $1 / 4$ sec. 32, T. 135 N., R. 106 W.), on U.S. Forest Service land (leased by Lyle Tennant) north of Pretty Butte, some $29 \mathrm{~km}(18 \mathrm{mi})$ northwest of Marmarth, in Slope County, North Dakota. In July of 1964, Marshall and his sons met our field crew (Jack W. Crawford, Michael F. Archbold, and I) shortly after dawn on our first morning in the field and then returned several times from his home in Ekalaka, Montana, to help with digging, as well as with planning and teaching us field techniques in the extraction of a large dinosaur. We could not have excavated and transported this specimen to UND without Marshall's aid and the support of the National Science Foundation and the North Dakota Geological Survey, and the assistance of nearby ranchers, the Slope County Board of Commissioners, and members of the North Dakota National Guard (including Maj. Gen. LaClair Melhouse and Chief Warrant Officer Bryan Baldwin). In these efforts, Marshall Lambert exemplified the kindness and helpfulness of a person dedicated to his craft and of the people of this part of the country.

We were able to obtain funding in 1983 (chiefly from the AMAX Foundation and Fellows of the University of North Dakota) to restore and display the skull. As Marshall lived so far away, our laboratory staff (Gary L. Stefanovsky, Wade D. Steig, and I) called on Bruce R. Erickson of the Science Museum of Minnesota for technical assistance, which was graciously given. Early on, we had thought this specimen belonged to Triceratops brevicornis Hatcher, but as preparation advanced, it seemed more appropriately assigned to $T$. prorsus Marsh. Recently Ostrom and Wellnhofer $(1986,1990)$ suggested that all named species of Triceratops were conspecific morphologic variants of $T$. horridus (Marsh). This view was supported by Lehman (1990), whose studies of ontogenetic variability in chasmosaurine genera also indicated sexual dimorphism in all ceratopsids. He suggested that Lull's $(1915,1933)$ " $T$. brevicornis $-T$. prorsus $-T$, horridus lineage" comprises female individuals. The heavy, rounded, strongly fused epoccipitals, and an indication of widespread, forwardly inclined, supraorbital horncores suggest that the UND specimen (Cat. No. 3000.) was an old female of Triceratops horridus. 


\title{
CONTRIBUtions to The MARShall LAMbert Symposium
}

Lehman, T.M., 1990, The ceratopsian subfamily Chasmosaurinae: Sexual dimorphism and systematics, in Carpenter, Kenneth, and Currie, P.J., eds., Dinosaur systematics: Approaches and perspectives: New York, Cambridge University Press, p. 211-229.

Lull, R.S., 1915, The mammals and horned dinosaurs of the Lance Formation of Niobrara County, Wyoming: American Journal of Science, v. 34, no. 3, p. 477-478.

Lull, R.S., 1933, A revision of the Ceratopsia or horned dinosaurs: Peabody Museum of Natural History, Memoir 3 (pt. 3), 175 p.

Ostrom, J.H., and Wellnhofer, Peter, 1986, The Munich specimen of Triceratops with a revision of the genus: Zitteliana Abhandlungen der Bayerischen Staatssammmlung für Paläontologie und historische Geologie, v. 14, p. 111-158.

Ostrom, J.H., and Wellnhofer, Peter, 1990, Triceratops: An example of flawed systematics, in Carpenter, Kenneth, and Currie, P.J., eds., Dinosaur systematics: Approaches and perspectives: New York, Cambridge University Press, p. 245-254.

\section{THE TERMINAL CRETACEOUS MANSON IMPACT STRUCTURE OF IOWA AND ITS POSSIBLE INFLUENCE ON K/T EVENTS IN THE WESTERN INTERIOR OF NORTH AMERICA}

\author{
Brian J. Witzke and Raymond R. Anderson \\ Iowa Department of Natural Resources, Geological Survey Bureau, \\ Iowa City, IA 52242-1319
}

The Manson Impact Structure of northern Iowa is the largest well-preserved impact structure in the United States ( $35 \mathrm{~km}$ diameter). Its ${ }^{40} \mathrm{Ar} /{ }^{39} \mathrm{Ar}$ age of $65.4 \pm 0.4 \mathrm{Ma}$ (Kunk and others, 1993) is indistinguishable from the age of the Cretaceous-Tertiary (K/T) boundary. Although multiple impact events now seem likely to have occurred at or near the end of the Cretaceous, including the probable giant structure at Chicxulub, Yucatan (Hildenbrand and others, 1991), the Manson structure is of special interest because of its geographic proximity to documented $\mathrm{K} / \mathrm{T}$ boundary sections in the Western Interior of North America. Manson is considered a likely source for some of the impact ejecta identified in the iridium-enriched impact layer of the K/T boundary layer in the Western Interior (Shoemaker and Izett, 1992). The maximum sizes of shocked quartz grains in $\mathrm{K} / \mathrm{T}$ boundary layers worldwide generally decrease with increasing distance from Manson. A recent drilling program in the Manson structure, cosponsored by the U.S. Geological Survey and the Iowa Geological Survey Bureau, has identified a variety of impact-related rock types (Anderson and others, in press) and refined our understanding of the general internal structure of the feature (for a synthesis of previous studies, see Hartung and Anderson, 1988). Three major structural terranes are identified: 1) a broad "central peak" of Precambrian basement rocks uplifted 6-7 km;2) an outer "terrace terrane" of complex downdropped blocks, including Cretaceous stratigraphic units structurally preserved far to the east of their present-day erosional margins across the Dakotas; and 3) an intermediate "crater moat." An overturned ejecta flap of stratigraphically inverted Proterozoic and Phanerozoic blocks and clasts is identified in one drill core from the terrace terrane, in a region downdropped at least $600 \mathrm{~m}$ relative to the crater margin. Crater modeling indicates that 


\section{Contributions to The Marshall Lambert Symposium}

faulting within the terrace terrane and uplift of the central peak would have occurred within seconds to minutes after impact. Impact-related rocks include two general types of breccias: 1) crystalline clast breccias (CCB), dominated by clasts of Precambrian basement lithologies (gneiss, granite, minor mafics) that incorporate clasts of accretionary melt-rock material (some with isotropic domains of apparently largely unaltered glass) and minor Proterozoic sedimentary rocks; and 2) sedimentary clast breccias (SCB), dominated by clasts of Phanerozoic shales and carbonates. CCBs were identified as blanketing the crystalline basement rocks of the central peak and display contrasting matrix lithologies, including 1) a lower interval with a sandy argillaceous matrix, and 2) an overlying unit with an altered melt-rock matrix displaying regions of flow-banding (interpreted as the impact melt layer). Clasts and grains within the CCBs show abundant planar deformation features (PDFs), especially quartz with multiple sets of shock lamellae, features unique to impact events. Some clasts are partially to completely melted, and many are modified by early postimpact hydrothermal alteration (Crossey and McCarville, 1993). The CCBs overlie relatively intact large blocks of Precambrian basement rocks on the central peak, which incorporate pods or dikes of $\mathrm{CCB}$ and display thin pseudotachylite (frictional melt) veins generated along fracture offsets.

Mineral crystals in these basement rocks also display abundant PDFs. By contrast, the SCBs are known to blanket all three structural terranes in the crater. The most abundant SCB contains only scattered rare clasts of Precambrian basement lithologies, and melt-rock clasts are rare to absent. These breccias, however, contain a disproportionately high percentage of Cretaceous shale, mudstone, and sandstone clasts, including contorted large blocks up to $75 \mathrm{~m}$ in diameter. Isolated, well-preserved Cretaceous foraminifer tests are scattered to common in SCB matrix. A layer of SCB was deposited across the central peak and is preserved in a central depression where it locally incorporated clasts of impact melt-rock into its base.

The disproportionate dominance of Cretaceous lithologies in the SCBs, when compared to the total volume of crustal material excavated during transient cratering, suggests that much of the contained Cretaceous blocks and other materials were derived by sedimentary mass transport from the crater margin, not by ejecta fallback. Unstable scarps probably existed around the crater margin immediately following excavation of the transient crater and as unstable footwall scarps associated with the episode of normal block faulting during formation of the terrace terrane area. The upper strata of these scarps was dominated by Cretaceous sediments (an estimated $300 \mathrm{~m}$ of Cenomanian through Maastrichtian strata) and, along with the ejecta blanket, presumably served as the source for the bulk of the SCB material. These Cretaceous blocks, clasts, and matrix provide a record of Cretaceous deposits now largely eroded from the eastern margin area of the Western Interior. The presence of Paleozoic and rare Proterozoic and melt-rock lithologies identify the ejecta component of the SCB, incorporated chaotically with the mass of transported Cretaceous material during emplacement. Therefore, the SCB was likely transported from the crater rim by gravitationally driven mass wasting, coincident with and immediately following large-scale fault movements associated with the formation of the terrace terrane and the uplift of the central peak. This emplacement of the SCB included the transport of material, in thickness known to exceed $200 \mathrm{~m}$, up to $15 \mathrm{~km}$ or more laterally, to cover all regions including the center of the Manson structure. 


\section{Contributions to The Marshall LAMbert Symposium}

The scale of movement associated with emplacement of the SCB is hard to comprehend, and whether gravity-driven landslide alone was sufficient to accomplish the task. The scale of the emplacement raises an intriguing question: Was the Manson site dry land at the time of impact or was the site covered by a shallow seaway at that time? Some workers (e.g., Feldman, 1972) have raised the possibility that the Western Interior seaway did not completely withdraw at the end of the Cretaceous, noting that the eastward-thinning Hell Creek-Ludlow nonmarine package is sandwiched between marine units below (Pierre-Fox Hills) and above (Cannonball), similar to other Cretaceous nonmarine wedges (e.g., Two Medicine-Judith River). If the trend of Hell Creek thinning is extrapolated eastward beyond the present-day erosional edge, the Western Interior seaway may have remained in the eastern Dakotas and western Iowa at the time of the $\mathrm{K} / \mathrm{T}$ boundary. If the Manson impact occurred in a shallow sea, tsunami-like currents may have swept back into the crater following impact, possibly transporting enormous amounts of material.

What effects might be predicted to have occurred at the end of the Cretaceous in the Western Interior as a result of the nearby Manson impact? First, about $2.2 \times 10^{21}$ Joules (Anderson and Hartung, 1992) would have been released on the basis of a tentative scaling of known blast zones to a Manson-size impact; the effects of the atmospheric shock wave generated from the Manson blast would have been dramatic. Second, all combustible material within about $200 \mathrm{~km}$ of Manson would have been ignited, standing vegetation completely devastated out to a distance of approximately $600 \mathrm{~km}$. Third, the force of the blast was sufficient to kill most exposed terrestrial animals in its wake as far as $1000 \mathrm{~km}$ and the shock wave could have knocked human-sized animals off their feet as far away as $1300 \mathrm{~km}$. These distances intersect various K-T boundary sections in the Western Interior, including areas in south-central North Dakota $(650-750 \mathrm{~km})$, eastern Wyoming (including Teapot Dome) $(800-950 \mathrm{~km})$, southwest North Dakota (including the Bowman area) $(850 \mathrm{~km})$, the Raton Basin $(1050-1100 \mathrm{~km})$, and the type area of the Hell Creek Formation $(1100 \mathrm{~km})$. Fourth, significant amounts of ejecta were generated from the Manson impact, with estimates ranging from 600 to $1200 \mathrm{~km}^{3}$ (Anderson and Hartung, 1992; Roddy and Shoemaker, 1993), about 15 percent of which would have been injected above the tropopause. The impacting body (comet or asteroid) completely vaporized on impact, providing a source of extraterrestrial material, likely to be iridium-enriched. Therefore, the Manson impact probably contributed ejecta (including large amounts of shocked quartz) and extraterrestrial material to the $\mathrm{K} / \mathrm{T}$ boundary sections in the Western Interior and elsewhere in the world (Anderson and Hartung, 1992).

Although the Manson structure is significantly smaller than the current estimates of the size of the Chicxulub structure, the Manson impact remains one of the most remarkable events in the Cretaceous history of the North American Western Interior and may have had a truly significant effect on the biosphere. Many new details concerning the Manson structure will be emerging in the near future as a consortium of researchers continues to study the newly drilled core materials.

Anderson, R.R., and Hartung, J.B., 1992, The Manson Impact Structure: Its contribution to impact materials observed at the Cretaceous-Tertiary boundary: Proceedings Lunar and Planetary Science, v. 22, p. 101-110. 


\title{
CONTRibutions to The MARShall LAMBert Symposium
}

Anderson, R.R., Hartung, J.B, Witzke, B.J., Shoemaker, E.M., and Roddy, D.J., in press, Preliminary results of U.S. Geological and Iowa D.N.R. Geological Survey Bureau Manson Core Drilling Project, in Dressler, B., ed., Proceedings of the Sudbury 1992 Conference on Large Meteorite Impacts and Planetary Evolution: Geological Society of America Special Paper.

Crossey, L.J., and McCarville, P., 1993, Post-impact alteration of the Manson Impact Structure [abs.]: Lunar and Planetary Science Conference, v. 24, p. 351-352.

Feldman, R.M., 1972, Stratigraphy and paleoecology of the Fox Hills Formation (Upper Cretaceous) of North Dakota: North Dakota Geological Survey, Bulletin 61, 65 p.

Hartung, J.B., and Anderson, R.R., 1988, A compilation of information and data on the Manson Impact Structure: Lunar and Planetary Institute, Technical Report 88-08, 32 p.

Hildenbrand, A.R., Penfield, G.T., Kring, D.A., Pilkington, M., Camargo, A.Z., Jacobsen, S.B., and Boynton, W.V., 1991, Chicxulub crater: A possible Cretaceous/Tertiary boundary impact crater on the Yucatan Peninsula, Mexico: Geology, v. 19, p. 867-871.

Kunk, M.J., Snee, L.W., French, B.M., Harlan, S.S., and McGee, J.J., 1993, Preliminary ${ }^{40} \mathrm{Ar} /{ }^{39} \mathrm{Ar}$ age spectrum and laser probe dating of the M-1 core of the Manson Impact Structure, Iowa [abs.]: Lunar and Planetary Science Conference, v. 24, p. 835-836.

Roddy, D.J., and Shoemaker, E.M., 1993, The Manson impact crater: Estimation of the energy of formation, possible size of the impacting asteroid or comet, and ejecta volume and mass [abs.]: Lunar and Planetary Science Conference, v. 24, p. 1211-1212.

Shoemaker, E.M., and Izett, G.A., 1992, Stratigraphic evidence from western North America for multiple impacts at the $\mathrm{K} / \mathrm{T}$ boundary [abs.]: Lunar and Planetary Science Conference, v. 23, p. 1293-1294.

SILCRETE:

A DISTINCTIVE ROCK TYPE RELATED TO K/T BOUNDARY EVENTS

\author{
Barbara D. Wehrfritz \\ Consulting Geologist, 1820 Wyoming Avenue, Meeteetse, WY 82433
}

Silcrete is a hard, grey, sedimentary rock made of silt-sized detrital quartz grains in a matrix of interlocking microcrystalline quartz. Silcrete beds occur in North Dakota in the Rhame bed, which is used locally to mark the top of the Paleocene-age Slope Formation. Silcrete beds also occur just below the Cretaceous-Tertiary (K/T) boundary (lithostratigraphically determined), at the K/T boundary, and at various horizons in strata of Paleocene age throughout the Western Interior. Silcrete beds are also found worldwide in association with the $\mathrm{K} / \mathrm{T}$ boundary and Paleocene-age rocks.

Silcrete deposits were first recognized in North America, near Rhame, North Dakota, by the writer in 1978. Dr. William Clemens (University of California at Berkeley), who the writer met while visiting Marshall Lambert in Ekalaka, Montana, suggested a review of the Australian geologic literature because the siliceous rock in this area looked like silcrete he had seen in Australia. 


\title{
CONTRIBUtions to The MARShall LAMBERT SyMPOSIUM
}

The exact origin of silcrete is still controversial, but it is generally accepted to be part of a paleosol, indicating a stable climate continuous over a significant length of time. Little mention or acknowledgment of silcrete is made in modern paleosol studies, although it is part of the calcrete-silcrete-ferricrete duricrust continuum. Silcrete is significant in many ways in that it 1) has a distinctive and recognizable lithology; which is similar in appearance wherever it is found; 2) can be traced over large areas, even using air photos, making it a mappable unit; and 3) may prove to be an important chronostratigraphic marker associated with the $\mathrm{K} / \mathrm{T}$ boundary, similar to the use of the iridium-enriched layer. Additional study of silcrete deposits at the $\mathrm{K} / \mathrm{T}$ boundary may provide geologists with another important tool in interpreting events at this time.

\section{SOME IMPLICATIONS OF CHANGES IN PALEODRAINAGE DIRECTIONS BELOW AND ABOVE AN UNCONFORMITY WITHIN THE PALEOCENE TONGUE RIVER SANDSTONES NEAR EKALAKA, SOUTHEASTERN MONTANA}

\author{
Edward S. Belt and Tekla Harms \\ Department of Geology, Amherst College, Amherst, MA 01002 \\ Edward C. Beutner \\ Department of Geology, Franklin and Marshall College, Lancaster, PA 17604 \\ Walter Coppinger \\ Geology Department, Trinity University, San Antonio, TX 78212 \\ John A. Diemer \\ Department of Geography and Earth Sciences, University of North Carolina at Charlotte, \\ Charlotte, NC 28223
}

In July 1991, Susan Vuke-Foster (Montana Bureau of Mines and Geology) and Ed Belt discovered an angular unconformity 10 to $25 \mathrm{~m}(32.8$ to $82.0 \mathrm{ft})$ above the base of strata previously mapped (Bergantino, 1980) as the Tongue River Member of the Fort Union Formation. Seven students, directed by the writers in the summer of 1992, made careful field examinations of all the Paleocene strata in a $90-\mathrm{km}^{2}\left(35-\mathrm{mi}^{2}\right)$ study area north and southeast of Ekalaka, in Carter and southern Fallon Counties, Montana. Paleocurrent vectors were summarized in azimuthal histograms and microfault poles were plotted on stereonets using a computer in Ekalaka. The results of these analyses were then field checked. These efforts produced five senior honors theses from Amherst, Carleton, and Whitman Colleges in May 1993.

The unconformity was found to extend throughout most of the study area and to be angular, where blocks (Clark, 1993) of underlying rippled sandstone had rotated from the horizontal, but to be disconformable where it had not rotated. The rippled sandstone is a mappable unit 20 to $30 \mathrm{~m}$ (65.6 to $98.4 \mathrm{ft}$ ) thick, covering an area of $340 \mathrm{~km}^{2}\left(135 \mathrm{mi}^{2}\right)$. It is lithologically distinguishable from the conformably underlying facies of the Ludlow Member of the Fort Union Formation and from the newly restricted overlying Tongue River Member, with which it is both conformable and unconformable. Most, but not all, of the strata of the Tongue River in the study area are represented by the massive, cliff-forming Medicine Rocks Sandstone. 


\section{CONTRibutions to The Marshall LAMbert SyMPOSIUM}

Late Torrejonian (middle Paleocene) mammalian remains occur near the base of the Medicine Rocks Sandstone (e.g., Mehling Site; Archibald and others, 1987) within the study area. Hence the unconformity mentioned above is pre-late Torrejonian in age. Pollen from the P-1 pollen zone (Nichols and Brown, 1992) was identified by Doug Nichols (U.S. Geological Survey, written comm., 1993) from the youngest coal bed in the Ludlow Member below the unnamed rippled sandstone. Nichols and Brown (1992, and earlier work cited therein) indicated that the P-1 pollen zone spans the Puercan (early Paleocene) and early Torrejonian. Hence the unconformity is post-early Torrejonian.

Paleodrainage directions, based on channelbelt sandstones in the Ludlow Member of the Fort Union Formation, trend northeast through most of the eastern margin of the Powder River Basin (Brown, 1993). Similar trends are also found in the Ekalaka study area (Abell, 1993; Cole, 1993), in the Cave Hills district, South Dakota (Goodrum, 1983), and between these two areas (Susan Vuke-Foster, unpubl. map data, 1990). Hence the intervening Black Hills district was not a significant obstruction to the direction of fluvial drainage trends during early Paleocene. In contrast, paleodrainage directions trend to the east and southeast in the strata of the same age in the Miles City coal field (Belt and others, 1992; Brown, 1993), and to the south and southeast along the Little Missouri River of southwestern North Dakota (Belt and others, 1984).

The apparent conflict between the northeast and southeast trends in paleodrainage can be resolved by a westward embayment in the margin of the Cannonball Sea along the North Dakota-South Dakota border. This event may have become more pronounced during the transgression of the Oyster tongue of the Cannonball Sea in North Dakota (Belt and others, 1984). Perhaps the unnamed rippled sandstone, which also contains Skolithos-like burrows, is a marginal marine deposit related to the transgression.

The pollen dates (P-1 pollen zone, Doug Nichols, written comm., 1993), from coals in the upper Ludlow and in the so-called Tongue River sandstones (Roger Colton, U.S. Geological Survey, unpubl. geologic map) on the Mill Iron Road crossing of Box Elder Creek, suggest the need for a revision of the stratigraphy there and east of the Box Elder. The writers subscribe to the suggestion (Goodrum, 1983) that Sandstone D and Sandstone E in the North Cave Hills are at least partially marine (see also Cvancara and Hoganson, 1993) and ought to be mapped as the Cannonball Member of the Fort Union Formation, rather than as Tongue River Member (as per Pipperingos and others, 1965). Ophiomorpha and Skolithos burrows were found in Sandstone $\mathrm{F}$ by our group in the North Cave Hills area (guided by Jack Redden of the South Dakota School of Mines, 1992). None of the North Cave Hills deposits have been pollen dated (Nichols, oral comm., 1992) to aid in the chronostratigraphic correlation of these strata.

Paleodrainage directions from channelbelts of the Tongue River Member above the unconformity trend southeast throughout the Ekalaka study area. These trends and their relationship to various possible causes for the unconformity need to be resolved in terms of 1) possible movement along the Miles City Arch related to uplift in the Black Hills, 2) the welldated and widespread middle Paleocene (mid-Torrejonian) unconformity in the Bighorn Basin (Hicks, 1993), and 3) the relevance of eustasy within the Cannonball Sea. 


\section{CONTRibutions to The MARSHALl LAMBERT SyMPOSIUM}

Abell, R.H., 1993, Provenance of the Ludlow and Tongue River sand deposits, Fort Union Formation (Paleocene), southeastern Montana: Constraints on the timing of the Bighorn uplift: Sixth KECK Symposium on Research in Geology (abstracts volume), p. 87-90.

Archibald, J.D., Clemens, W.A., Gingerich, P.D., Krause, D.W., Lindsay, E.H., and Rose, K.D., 1987, First North American land mammal ages of the Cenozoic Era, in Woodburne, M.O., ed., Cenozoic mammals of North America: Berkeley, University of California Press, p. 24-76.

Belt, E.S., Flores, R.M., Warwick, P.D., Conway, K.M., Johnson, K.R., and Waskowitz, R.S., 1984, Relationship of fluviodeltaic facies to coal deposition in the lower Fort Union Formation (Paleocene), southwestern North Dakota, in Rahmani, R.A., and Flores, R.M., eds., Sedimentology of coal and coal-bearing sequences, International Association of Sedimentologists, Special Publication no. 7, p. 177-195.

Belt, E.S., Sakimoto, S.E.H., and Rockwell, B.W., 1992, A drainage-diversion hypothesis for the origin of widespread coal beds in the Williston Basin: Examples from Paleocene strata, eastern Montana, in Sholes, M.A., ed., Coal Geology of Montana, Montana Bureau of Mines and Geology, Special Publication no. 102, p. 21-60.

Bergantino, R.N., 1980, Ekalaka Geology Sheet: Montana Bureau of Mines and Geology, Map MA 1-A, scale 1:250,000, with notes.

Brown, J.L., 1993, Sedimentology and depositional history of the lower Paleocene Tullock Member of the Fort Union Formation, Powder River Basin, Wyoming and Montana: U.S. Geological Survey, Bulletin 1917-L, 42 p., 3 pls.

Clark, I.H.D., 1993, An analysis of deformed strata in the Paleocene Fort Union Formation near Ekalaka, Montana: Sixth KECK Symposium on Geology (abstracts volume), p. 103-106.

Cole, B.S., 1993, Early and mid-Paleocene paleodrainage analysis and implications for regional vs. local allogenic processes, Ekalaka area, southeastern Montana: Sixth KECK Symposium on Geology (abstracts volume), p. 91-94.

Cvancara, A.M., and Hoganson, J.W., 1993, Vertebrates of the Cannonball Formation (Paleocene) in North and South Dakota: Journal of Vertebrate Paleontology, v. 13, no. 1, p. 1-23.

Goodrum, C.K., 1983, A paleoenvironmental and stratigraphic study of the Paleocene Fort Union Formation in the Cave Hills area of Harding County, South Dakota [M.Sc. thesis]: Rapid City, South Dakota School of Mines and Technology, $134 \mathrm{p}$.

Hicks, J.F., 1993, Chronostratigraphic analysis of the foreland basin sediments of the latest Cretaceous, Western Interior, U.S.A. [Ph.D. thesis]: New Haven, Yale University, 333 p.

Nichols, D.J., and Brown, J.L., 1992, Palynostratigraphy of the Tullock Member (lower Paleocene) of the Fort Union Formation in the Powder River Basin, Montana and Wyoming: U.S. Geological Survey, Bulletin 1917-F, 35 p., 10 pls.

Pippiringos, G.N., Chisholm, W.A., and Kepferle, R.C., 1965, Geology and uranium deposits in the Cave Hills area, Harding County, South Dakota: U.S. Geological Survey, Professional Paper 476-A, 64 p. 


\title{
CONTRIBUtions to The MARShall LAMBERT SyMPOSIUM
}

\section{THE STRATIGRAPHY AND BIOCHRONOLOGY OF THE CHADRON, BRULE, AND ARIKAREE FORMATIONS IN NORTH DAKOTA}

\author{
Edward C. Murphy and John W. Hoganson \\ North Dakota Geological Survey, Bismarck, ND 58505-0840 \\ Nels F. Forsman \\ Department of Geology and Geological Engineering, University of North Dakota, \\ Grand Forks, ND 58203-8358
}

The Chadron, Brule, and Arikaree Formations are, for the most part, poorly exposed in small and scattered outcrops in southwestern North Dakota. The best exposures are found in the Chalky Buttes, Little Badlands, and Killdeer Mountains in Slope, Stark, and Dunn Counties, respectively. Previous studies have attempted to date and correlate these rock units with varying degrees of success.

Thirty-one geologic sections were measured and twelve holes cored on butte tops to characterize and correlate formations. Prospecting for fossils took place at all known exposures to collect specimens for study to establish biochronologic control. Tuffs were sampled for fission-track dating and trace element fingerprinting from two localities in the Little Badlands and from one locality in the Killdeer Mountains. Thirty claystone samples from the Chadron and Golden Valley Formations were x-rayed for clay analysis. Eighty thin sections were made of sandstone and carbonate samples for petrographic characterization.

The Chadron Formation can be confidently traced lithologically throughout this area. The Chalky Buttes Member, consisting of yellowish green to white sandy mudstones, sandstones, and conglomerates, is the lower member of the Chadron Formation. The South Heart Member is the overlying sequence of gray to brown smectitic claystones and interbedded limestones of the Chadron Formation. The presence of brontothere remains in both of these members suggests a Chadronian age.

The pinkish brown mudstones and siltstones of the Brule Formation are easily distinguished lithologically and by color from the underlying Chadron and overlying Arikaree Formations. However, it is difficult to distinguish between conglomeratic sandstones in the upper part of the Brule and those in the Arikaree Formation. We have based our placement of these conglomeratic sandstones, found in either the Brule or Arikaree Formations, on the lithologic character of the overlying rocks. A previously unnamed tuff, the Antelope Creek tuff, occurs in the lower Brule Formation in the Little Badlands. The Brule Formation in North Dakota contains Orellan- to Whitneyan-age mammal faunas.

The Arikaree Formation is represented by conglomeratic sandstones, tuffs, and carbonates in southwestern North Dakota. Conglomeratic butte-capping sandstones were placed in the Arikaree Formation. An age of $25.1 \pm 2.2 \mathrm{Ma}$ (Late Arikareean to early Hemingfordian) was determined from fission-track dating of volcanic glass in the middle of the Arikaree Formation in the Killdeer Mountains. The few mammalian remains in the Arikaree Formation in North Dakota suggest a late Whitneyan to late Arikareean age. 


\title{
CONTRibutions to The MaRShall LAMBert Symposium
}

\section{THE LATE CRETACEOUS (MAASTRICHTIAN) FLORA OF THE HELL CREEK FORMATION IN SOUTHWESTERN NORTH DAKOTA}

\author{
Kirk R. Johnson \\ Department of Earth Sciences, Denver Museum of Natural History, \\ Denver, Colorado 80205
}

The valley of the Little Missouri River in southwestern North Dakota contains extensive exposures of the Late Cretaceous Hell Creek Formation. While the Lancian-age vertebrate fauna from the Hell Creek and time-equivalent Lance Formation is well known from several localities in central and eastern Montana, Wyoming, southwestern North Dakota, and western South Dakota, extensive recovery of plant macrofossils has only occurred in southwestern North Dakota. Fossil plants were collected here in the late 1930s by Roland Brown from the U.S. Geological Survey (USGS) and by Erling Dorf and students from Princeton University. Since 1981, I have collected fossil plants from the 110-meter-thick Hell Creek Formation and overlying Paleocene Ludlow Member of the Fort Union Formation (Ludlow and Slope Formations of North Dakota Geological Survey usage). Over 12,000 specimens have been collected from 36 Ludlow and 66 Hell Creek quarry sites in Slope and Bowman Counties. The fossil plant specimens are housed at the Yale Peabody Museum in New Haven, Connecticut, and the Denver Museum of Natural History. The 102 plant quarries occur in a lithostratigraphic framework based on over 40 measured stratigraphic sections calibrated to the geochronologic time scale using magnetostratigraphy (paleomagnetic analyses by Lisa Tauxe, Dave Clark, and Jason Hicks indicate that the Hell Creek Formation represents the last 2-3 million years of the Cretaceous in North Dakota). Palynology is the most precise technique for locating the Cretaceous-Tertiary (K/T) boundary in terrestrial rocks. Douglas J. Nichols (USGS) has studied the palynomorphs of the sections in Slope and Bowman Counties. The K/T boundary near Marmarth lies near, but not exactly at, the Hell Creek-Ludlow formational contact. The K/T boundary is marked by the extinction of dinosaurs and very high levels of plant extinction ( 30 percent of the palynomorphs and 80 percent of the leaf morphotypes). At Pyramid Butte, north of Marmarth, the palynological K/T boundary is associated with an iridium anomaly and shocked mineral grains.

The megaflora of the Hell Creek Formation is dominated by flowering plants (angiosperms) which account for approximately 90 percent of both species and specimens. The remaining 10 percent of the flora is composed of conifers, cycadophytes, ferns, sphenopsids, and bryophytes. A large percentage of the flora has not yet been formally described. Distinct floral changes occur within the Hell Creek Formation. The upper 20 meters of the formation has a flora that is very different from the flora of the lower 90 meters. The composition of the Hell Creek flora, as a whole, contrasts dramatically with slightly older Cretaceous floras such as those from the Meeteetse (Early Maastrichtian), Judith River (Campanian), and Two Medicine (Campanian) Formations and with the younger floras of the Fort Union (Paleocene) Formation. The older floras have a much higher relative proportion of conifers, cycadophytes, and ferns. The younger Fort Union floras have the same relative proportion of major plant groups but a completely different species composition and a much lower species richness. 


\title{
CONTRibutions to The MARShall LAMBERT Symposium
}

On the basis of these paleobotanical studies, the Denver Museum of Natural History is presently building a 1300-square-foot reconstruction of a forest that represents the flora of the upper part of the Hell Creek Formation. This exhibit will require fabrication of approximately 70,000 leaves (and even a few dinosaurs), and will open to the public in late 1995.

\section{AN UNUSUAL OCCURRENCE OF PALEOCENE NONMARINE MOLLUSKS ON THE EAST FLANK OF THE CEDAR CREEK ANTICLINE, FALLON COUNTY, MONTANA}

\author{
Joseph H. Hartman \\ Energy \& Environmental Research Center, University of North Dakota \\ Grand Forks, ND 58202-9018
}

The "Melcher Snail Locality"* (Locality L49) is a highly fossiliferous bed of snails about $1.9 \mathrm{~km}(1.2 \mathrm{mi})$ northeast of the breaks of the Cedar Creek Anticline in northern Fallon County, Montana (T. 10 N., R. 59 E.). The faunule is unusual in that it contains 1) a diverse assemblage of freshwater mollusks in a stratigraphic interval that is generally unfossiliferous or of low diversity, 2) a relatively complete ontogenetic series of one particular taxon, and 3) specimens of a genus that is not otherwise well represented in the Paleocene of the northern Great Plains. The locality was referred to me by Marshall E. Lambert in 1977 while examining collections at the Carter County Museum, Ekalaka, Montana. Mr. Lambert collected specimens at his "north of Baker" locality in 1960 and had obtained a representative sample of the faunule. Additional material was subsequently collected in 1977 (with J.A. Milske), 1978 (with students from Carleton College and later with R.C. Holtzman), 1988, and 1989 (with D.W. Krause, T.J. Kroeger, and others). Collections from the approximately meter-thick shell bed were made in a shallow pit, some $50 \mathrm{~m}^{2}$ in size, on the north end of a grassed butte. The shell bed, barely discernible in the cover, extends southward along the crest of the hill. The pit was produced by farmers quarrying shells for a calcium carbonate feed supplement for their chickens.

Vuke-Foster and others (1986) assigned provisional geologic map units to the Paleocene strata of the Wibaux 30x60-minute Quadrangle. The stratigraphic sequence in the area of the Melcher Locality includes the uppermost Cretaceous Hell Creek Formation and the Paleocene $\mathrm{Tfu}_{1}$ and $\mathrm{Tfu}_{3}$ map units. Vuke-Foster and others (1986) correlated $\mathrm{Tfu}_{1}$ with the Ludlow Formation and $\mathrm{Tfu}_{3}$ with the Slope Formation, as recognized in the Little Missouri River drainage in adjacent North Dakota counties. The area of the Melcher Locality was mapped as $\mathrm{Tfu}_{3}$ (Vuke-Foster and others, 1986). The very minor rock outcrops at the south end of the butte are mottled, pale yellow silty claystones, claystones, and calcareous claystones indicative of this map unit. The slope of the butte is littered with large silcrete boulders let down from a higher, no longer preserved horizon. Employing field observations and mapping of VukeFoster and others (1986), a dip of slightly less than $1^{\circ}$ was derived for the strata about the locality. Its occurrence was calculated to be approximately $73 \mathrm{~m}$ above the Hell Creek-Tfu, 


\title{
CONTRIBUtions to The MARShall LAMBERT Symposium
}

On the basis of these paleobotanical studies, the Denver Museum of Natural History is presently building a 1300-square-foot reconstruction of a forest that represents the flora of the upper part of the Hell Creek Formation. This exhibit will require fabrication of approximately 70,000 leaves (and even a few dinosaurs), and will open to the public in late 1995.

\section{AN UNUSUAL OCCURRENCE OF PALEOCENE NONMARINE MOLLUSKS ON THE EAST FLANK OF THE CEDAR CREEK ANTICLINE, FALLON COUNTY, MONTANA}

\author{
Joseph H. Hartman \\ Energy \& Environmental Research Center, University of North Dakota \\ Grand Forks, ND 58202-9018
}

The "Melcher Snail Locality"* (Locality L49) is a highly fossiliferous bed of snails about $1.9 \mathrm{~km}(1.2 \mathrm{mi})$ northeast of the breaks of the Cedar Creek Anticline in northern Fallon County, Montana (T. 10 N., R. 59 E.). The faunule is unusual in that it contains 1) a diverse assemblage of freshwater mollusks in a stratigraphic interval that is generally unfossiliferous or of low diversity, 2) a relatively complete ontogenetic series of one particular taxon, and 3) specimens of a genus that is not otherwise well represented in the Paleocene of the northern Great Plains. The locality was referred to me by Marshall E. Lambert in 1977 while examining collections at the Carter County Museum, Ekalaka, Montana. Mr. Lambert collected specimens at his "north of Baker" locality in 1960 and had obtained a representative sample of the faunule. Additional material was subsequently collected in 1977 (with J.A. Milske), 1978 (with students from Carleton College and later with R.C. Holtzman), 1988, and 1989 (with D.W. Krause, T.J. Kroeger, and others). Collections from the approximately meter-thick shell bed were made in a shallow pit, some $50 \mathrm{~m}^{2}$ in size, on the north end of a grassed butte. The shell bed, barely discernible in the cover, extends southward along the crest of the hill. The pit was produced by farmers quarrying shells for a calcium carbonate feed supplement for their chickens.

Vuke-Foster and others (1986) assigned provisional geologic map units to the Paleocene strata of the Wibaux 30x60-minute Quadrangle. The stratigraphic sequence in the area of the Melcher Locality includes the uppermost Cretaceous Hell Creek Formation and the Paleocene $\mathrm{Tfu}_{1}$ and $\mathrm{Tfu}_{3}$ map units. Vuke-Foster and others (1986) correlated $\mathrm{Tfu}_{1}$ with the Ludlow Formation and $\mathrm{Tfu}_{3}$ with the Slope Formation, as recognized in the Little Missouri River drainage in adjacent North Dakota counties. The area of the Melcher Locality was mapped as $\mathrm{Tfu}_{3}$ (Vuke-Foster and others, 1986). The very minor rock outcrops at the south end of the butte are mottled, pale yellow silty claystones, claystones, and calcareous claystones indicative of this map unit. The slope of the butte is littered with large silcrete boulders let down from a higher, no longer preserved horizon. Employing field observations and mapping of VukeFoster and others (1986), a dip of slightly less than $1^{\circ}$ was derived for the strata about the locality. Its occurrence was calculated to be approximately $73 \mathrm{~m}$ above the Hell Creek-Tfu 


\section{Contributions to The MARShall LAMBert Symposium}

contact and about $37 \mathrm{~m}$ above the $\mathrm{Tfu}_{1}-\mathrm{Tfu}_{3}$ contact. In addition, the fossil horizon appears to be about $24 \mathrm{~m}$ above an in situ silcrete layer exposed a short distance to the southwest.

The Melcher Locality faunule is dominated by large snails of the Family Viviparidae, including numerous specimens of Viviparus sp. C and Campeloma nebrascense whitei Russell, and a few specimens of $V$. meeki Wenz (Hartman, 1984). Of significance are a number of small specimens of Viviparus sp. C that are interpreted as probably prenatal. The assemblage includes, in minor abundance, only the second report of a highly sculptured species of the Family Pleuroceridae, probably assignable to the genus Elimia (Goniobasis of earlier usage). A single specimen of a sculptured pleurocerid (?Goniobasis sp.) was reported by Van Alstine (1974) from the Slope Formation, associated with the lower tongue of the Cannonball Formation, in Slope County, North Dakota. The Melcher Locality snail faunule also includes Lioplacodes nebrascensis and L. tenuicarinata (Pleuroceridae), Hydrobia spp. (Hydrobiidae), Physa sp. (Physidae), and New Genus A limneaformis (incertae sedis). A very small portion of the shell mass of the locality consists of bivalves, including specimens of uncertain affinity assigned to Corbula (Corbulidae) and Sphaerium (Pisidiidae), and very fragmentary remains of freshwater mussels (Unionidae) assignable to indeterminate species of Plesielliptio and Rhabdotophorus.

A comparable assemblage, but of lower diversity, is known from a horizon between the tongues of the Cannonball Formation in western Slope County, North Dakota, on the west side of the Little Missouri River (Hartman, 1984; Locality L4232). The fossil assemblage and stratigraphic placement of the Melcher Locality indicate its probable lateral equivalence to the strata bearing the transgressive-regressive sequences of the Cannonball Sea. A comparison to other nonmarine molluscan localities, correlated with mammalian local faunas, suggests a postPuercan to pre-Ti3 (middle Tiffanian) Paleocene age for the Melcher Locality.

I am indebted to Mr. Lambert for information about and specimens from the Melcher Locality, and appreciative of the courtesy of the local landowners (Rising-Melcher) and support from the National Science Foundation.

Hartman, J.H., 1984, Systematics, biostratigraphy, and biogeography of latest Cretaceous and early Tertiary Viviparidae (Mollusca, Gastropoda) of southern Saskatchewan, western North Dakota, eastern Montana, and northern Wyoming [Ph.D. thesis]: Minneapolis, University of Minnesota, 928 p., 19 pls. [Dissertation Abstracts International, v. 45, no. 3].

Van Alstine, J.B., 1974, Paleontology of brackish-water faunas in two tongues of the Cannonball Formation (Paleocene, Danian), Slope and Golden Valley Counties, southwestern North Dakota [M.S. thesis]: Grand Forks, University of North Dakota, 101 p., 2 pls.

Vuke-Foster, S.M., Colton, R.B., Stickney, M.C., Wilde, E.M., Robocker, J.E., and Christensen, K.C., 1986, Geology of the Baker and Wibaux 30x60-minute quadrangles, eastern Montana and adjacent North Dakota: Montana Bureau of Mines and Geology, Geologic Map 41, 1 sheet. 


\title{
CONTRIBUtions to THE MARShall LAMBERT SyMPOSIUM
}

\section{DID PACHYCEPHALOSAURS (ORNITHISCHIA: DINOSAURIA) REALLY BUTT HEADS?}

\author{
Kenneth Carpenter \\ Department of Earth Sciences, Denver Museum of Natural History, \\ Denver, Colorado 80205
}

The hypothesis that pachycephalosaur dinosaurs used their massive dome heads in headto-head butting is reexamined. Such behavior would seem anatomically unlikely. Instead, flank butting is suggested by the available evidence.

Two types of flank butting are recognized. One type was seen in Pachycephalosaurus, Prenocephale, and Stegoceros, all of which have thickened cranial domes. Such domes would maximize the mass of the head in flank-directed blows. The second type of butting was seen in Stygimoloch. The squamosal horns seem to be an adaptation for causing maximum pain locally during flank butting, but without causing serious injury.

A new reconstruction of the skull and head of Stygimoloch is presented. The head restoration differs from previous versions in that the squamosal horns are directed more laterally than dorsally. In addition, the shelf above the orbital is much broader than in other pachycephalosaurs.

\section{THE MEDICINE POLE HILLS LOCAL FAUNA - THE FIRST DIVERSE CHADRONIAN (LATEST EOCENE)-AGE FAUNA FROM NORTH DAKOTA}

\author{
Dean A. Pearson \\ Department of Paleontology, Pioneer Trails Museum, Bowman, North Dakota 58623
}

Vertebrate fossils have been collected since 1989 from the lower part of the Chadron Formation, in the Medicine Pole Hills, seven miles south of Rhame, Bowman County, southwestern North Dakota. Although the Chadron Formation is exposed in other areas in the state, this is the first report of an abundant vertebrate local fauna of significant diversity. A preliminary faunal list is given in Table 1. On the basis of a brontotheriid, the Medicine Pole Hills Local Fauna is interpreted as Chadronian in age.

Outcrops of the Chadron Formation in the Medicine Pole Hills are few and restricted to butte tops. The thickness of these strata varies from a few centimeters to as much as $5.2 \mathrm{~m}$ (17 $\mathrm{ft}$ ), as measured in drill holes (E.C. Murphy, North Dakota Geological Survey, written comm., 1992). The deposits are composed of a brownish orange, medium- to fine-grained, unconsolidated arkosic sandstone, which overlies a thin conglomeratic layer. The base of this gravel lies unconformably on a cemented sandstone that is interpreted as part of the Bullion Creek Formation. 
Fossils were recovered from the brownish orange sandstones by surface prospecting and through the dry screening of bulk-sampled matrix. Isolated fragments of large bones (probably brontotheriid) were found in gravel deposits, but most are waterworn and heavily abraded. About 1800 specimens have been collected to date from the Medicine Pole Hills localities. The fauna is notable because of 1) its high diversity, especially in mammalian taxa; and 2) the appearance of crocodilians and tapirs, rarely found in Chadronian faunas. The nine orders represented by 18 mammalian taxa, so far identified, represent a highly diverse fauna when compared to other Chadronian localities in North America. Continuing study of the Medicine Pole Hills fauna, by members of the Pioneer Trails Museum, will undoubtedly add to our knowledge of the Chadronian fossil record in North Dakota.

Table 1

\section{Vertebrate Taxa of the Medicine Pole Hills Local Fauna}

\begin{tabular}{|c|c|}
\hline 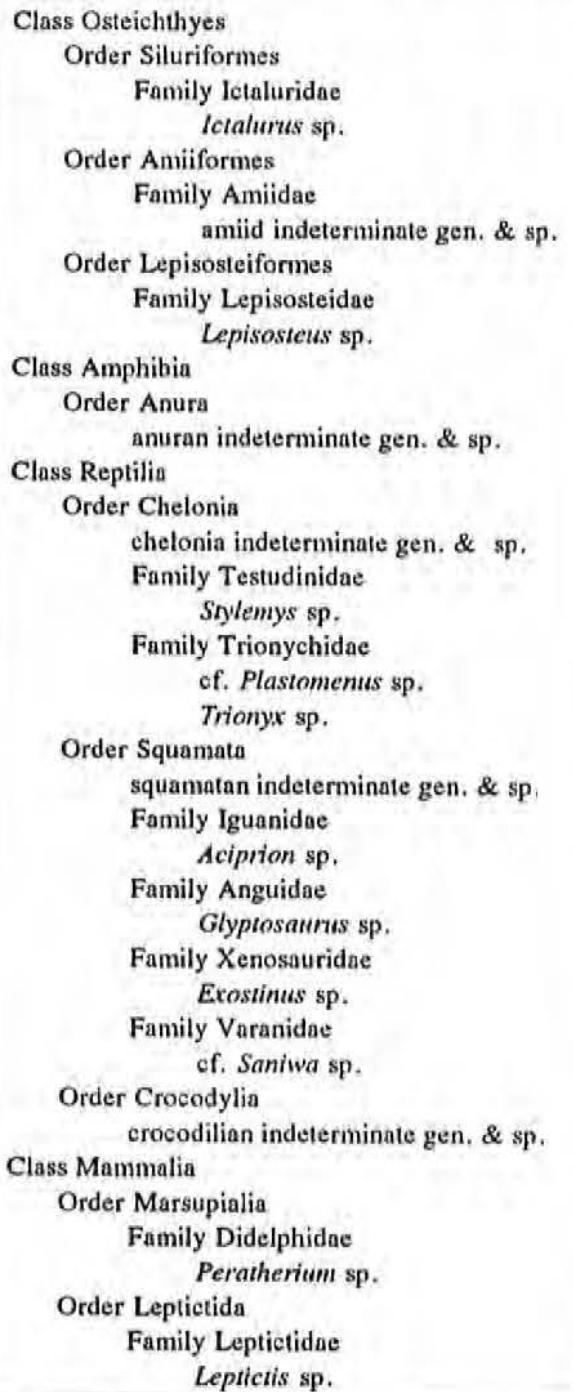 & $\begin{array}{c}\text { Class Mammulia, continued } \\
\text { Order Insectivora } \\
\text { indeterminate gen. \& sp. } \\
\text { Order Lagomorpha } \\
\text { Family Leporidae } \\
\text { Palaeolagus } \text { sp. } \\
\text { Order Rodentia } \\
\text { Family Ischyromyidac } \\
\text { cf. Ischyromys sp. } \\
\text { Family Eutypomyidae } \\
\text { Eutypomys sp. } \\
\text { Order Creodonta } \\
\text { Family Hyrenodontidae } \\
\text { cf. Hyaenodon sp. } \\
\text { Order Carnivora } \\
\text { Family Canidae } \\
\text { Hesperocyon sp. } \\
\text { Order Artiodactyla } \\
\text { Family Leptochoeridae } \\
\text { cf. Stibarus } \text { sp. } \\
\text { Family Tayassuidne } \\
\text { cf. Perchoenus sp. } \\
\text { Family Merycoidodontidae } \\
\text { cf. Merycoidodon sp. } \\
\text { Family Camelidae } \\
\text { Poebrotherium sp. } \\
\text { Family Leptomerycidae } \\
\text { Leptomeryx sp. } \\
\text { Frissodactyla } \\
\text { Family Equidae } \\
\text { Mesohippus sp. } \\
\text { Family Tapiridae } \\
\text { cf. Protapirus sp. } \\
\text { Family Helaletidae } \\
\text { cf. Colodon sp. } \\
\text { Family Brontotheriidae } \\
\text { cf. Brontops sp. } \\
\text { cf. Subhyracodon sp. }\end{array}$ \\
\hline
\end{tabular}




\title{
LATE PALEOCENE MAMMALIAN BIOCHRONOLOGY OF THE FORT UNION GROUP IN NORTH DAKOTA: PLESIADAPIS (PLESIADAPIFORMES) FROM THE BRISBANE, JUDSON, AND WANNAGAN CREEK QUARRY LOCAL FAUNAS
}

\author{
Allen J. Kihm \\ Department of Earth Science, Minot State University, Minot, ND 58702
}

This study focuses on Plesiadapis because it has been used to define the subdivisions of the Tiffanian (Ti) Mammal Age in North America. A reevaluation of previously described (Holtzman, 1978) Plesiadapis material from the Brisbane Locality (Slope Formation, Grant County), and Judson Localities (uppermost Slope Formation or lowermost Bullion Creek Formation, Morton County), together with new observations from the Wannagan Creek Quarry (upper Bullion Creek Formation, Billings County), provide the basis for a revised interpretation of the Ti3-Ti4 boundary in North Dakota.

Erickson (1991) reported the presence of Plesiadapis cf. P. fodinatus Jepsen and Plesiadapis sp. from Wannagan Creek Quarry. These identifications were based on preliminary analysis and are not supported by more detailed investigation. Plesiadapis fodinatus has curved and crested entoconids on $\mathrm{M}_{1}$ and $\mathrm{M}_{2}$, and talonids on $\mathrm{P}_{3}$ and $\mathrm{P}_{4}$ with distinct entoconids. None of the Wannagan Creek Quarry specimens show these characteristics, and there is no compelling evidence to suggest more than a single species is represented. Plesiadapis specimens from the Wannagan Creek Quarry are most similar to $P$. rex (Gidley) and $P$. churchilli Gingerich. Plesiadapis churchilli is larger than $P$. rex, has the $\mathrm{P}_{2}$ variably present, a significant diastema between the $\mathrm{P}_{3}$ and $\mathrm{I}_{1}$, and almost always has mesostyles on the $\mathrm{M}^{1}$. The Wannagan Creek Quarry sample has six specimens that preserve the mandible immediately anterior to the $\mathrm{P}_{3}$. In five of those specimens there is an alveolus for the $\mathrm{P}_{2}$, although in one of the five it is a very shallow pit. There is a significant diastema on all eight specimens preserving the anterior portion of the mandible. All Wannagan Creek Quarry specimens of $\mathrm{M}_{1}$ have a mesostyle. Comparison of tooth measurements show the Wannagan Creek Quarry specimens to be somewhat larger than the sample of $P$. rex from Cedar Point Quarry (Gingerich, 1976) and somewhat smaller than P. churchilli from Long Draw (Gingerich, 1976) and Roche Percée (Krause, 1978). Although $P$. churchilli is larger than $P$. rex, there is considerable overlap in size. On the basis of these characteristics, the sample from Wannagan Creek Quarry is interpreted as $P$. churchilli.

Specimens from the Judson Localities and Wannagan Creek Quarry samples show similar conditions for most characteristics. The only noted differences are the variable presence of a mesostyle on the $\mathrm{M}^{1}$ and the consistent presence of $\mathrm{P}_{2}$. The presence of a $\mathrm{P}_{2}$ is a characteristic of Plesiadapis rex, but the Judson sample is small (two specimens) and five of six specimens of $P$. churchilli from the Wannagan Creek Quarry retain a $P_{2}$. The Judson Localities specimens are unlike $P$. rex in generally having mesostyles on the $\mathrm{M}^{1}$ and in having a diastema between $P_{3}$ and $I_{1}$. The specimens from the Judson Localities are similar in size to the sample of $P$. rex from Cedar Point, and smaller than $P$. churchilli from Long Draw, Roche Percée, and Wannagan Creek Quarry. There is, however, considerable overlap in tooth size represented by these collections. Size suggests assignment of the Judson Localities specimens to $P$, rex; the 


\section{Contributions to The Marshall Lambert Symposium}

majority of the morphologic features are more like $P$. churchilli. The Judson Localities sample is here considered to be $P$. cf. $P$. churchilli.

The Judson and Brisbane Locality taxa, previously considered to be conspecific, show some interesting differences. Salient features seen in the Brisbane specimens include the variable presence of mesostyles on all upper molars, the absence of a paraconule on the $\mathrm{P}^{3}$, the variable presence of a centroconule on $\mathrm{I}^{\mathrm{1}}$, and smaller entoconids and a restricted opening of the talonid between the entoconid and the trigonid on the lower molars. The absence of a $\mathrm{P}^{3}$ paraconule is variable in Plesiadapis anceps Simpson, but is present in $P$. rex and $P$. churchilli. The absence of a centroconule on $\mathrm{I}^{1}$ is characteristic of $P$. anceps, but this cusp is present in $P$. rex and $P$. churchilli. The one Brisbane Locality specimen that lacks a centroconule has a very rugose area of enamel between the laterocone and mediocone. The variable presence of molar mesostyles is characteristic of $P$. rex. The specimens from the Brisbane Locality are smaller than specimens from the Judson Localities and those from the Wannagan Creek Quarry. They are comparable in size to and somewhat smaller than specimens of $P$. rex from Cedar Point.

The proportions of the lower dentition also distinguish the Brisbane sample from the Judson Localities and Wannagan Creek Quarry samples. The $\mathrm{P}_{4}$ length from the Brisbane sample is longer relative to the length of the $M_{1}$, with the average $M_{1}$ length divided by the average $\mathrm{P}_{4}$ length being 1.28. The same value for the Judson sample is 1.33 and the value for the Wannagan Creek Quarry sample is 1.38. This ratio reflects an apparent shortening of the $\mathrm{P}_{4}$ in Plesiadapis churchilli, which has the highest $\mathrm{M}_{1} / \mathrm{P}_{4}$ length value of any North American species of Plesiadapis. Considering the differences between the Plesiadapis specimens from the Judson and Brisbane Localities and the characteristics of the specimens in the Brisbane sample, the Brisbane specimens are best assigned to $P$. rex.

The Brisbane Locality is near the base of the Slope Formation. The exact stratigraphic position of the Judson Localities is undetermined, but they are near the top of the Slope Formation or base of the Bullion Creek Formation. The Wannagan Creek Quarry is near the top of the Bullion Creek Formation ( $20 \mathrm{~m}$ below the H T Butte lignite). The presence of Plesiadapis churchilli indicates Wannagan Creek fauna can be assigned to the Ti4 biochron. The presence of $P$. rex indicates a Ti 3 age for the Brisbane Locality fauna. The presence of $P$. cf. $P$. churchilli at the Judson Localities is not definitive, but suggests that this local fauna may belong to the Ti4 biochron. If this is true, then the Ti3-Ti4 transition occurs within the Slope Formation at a level significantly lower in the Fort Union Group section than previously thought. Confirmation of this interpretation will require a reanalysis of the Brisbane and Judson faunas in light of the better-defined biochronologic framework that now exists.

Erickson, B.R., 1991, Flora and fauna of the Wannagan Creek Quarry: Late Paleocene of North America: Science Museum of Minnesota, Science Publication, n.s. v. 7, no. 3, p. 1-19.

Gingerich, P.D., 1976, Cranial anatomy and evolution of early Tertiary Plesiadapidae (Mammalia, Primates): University of Michigan, Museum of Paleontology Papers on Paleontology, no. 15, p. 1-141.

Holtzman, R.C., 1978, Late Paleocene mammals of the Tongue River Formation, western North Dakota: North Dakota Geological Survey, Report of Investigations 65, p. 1-88. Krause, D.W., 1978, Paleocene primates from western Canada: Canadian Journal of Earth Science, v. 15 , no. 8 , p. $1250-1271$. 
ThE MARShall LAMBert SyMPOSIUM

\section{Part II:}

\section{BANQUET}




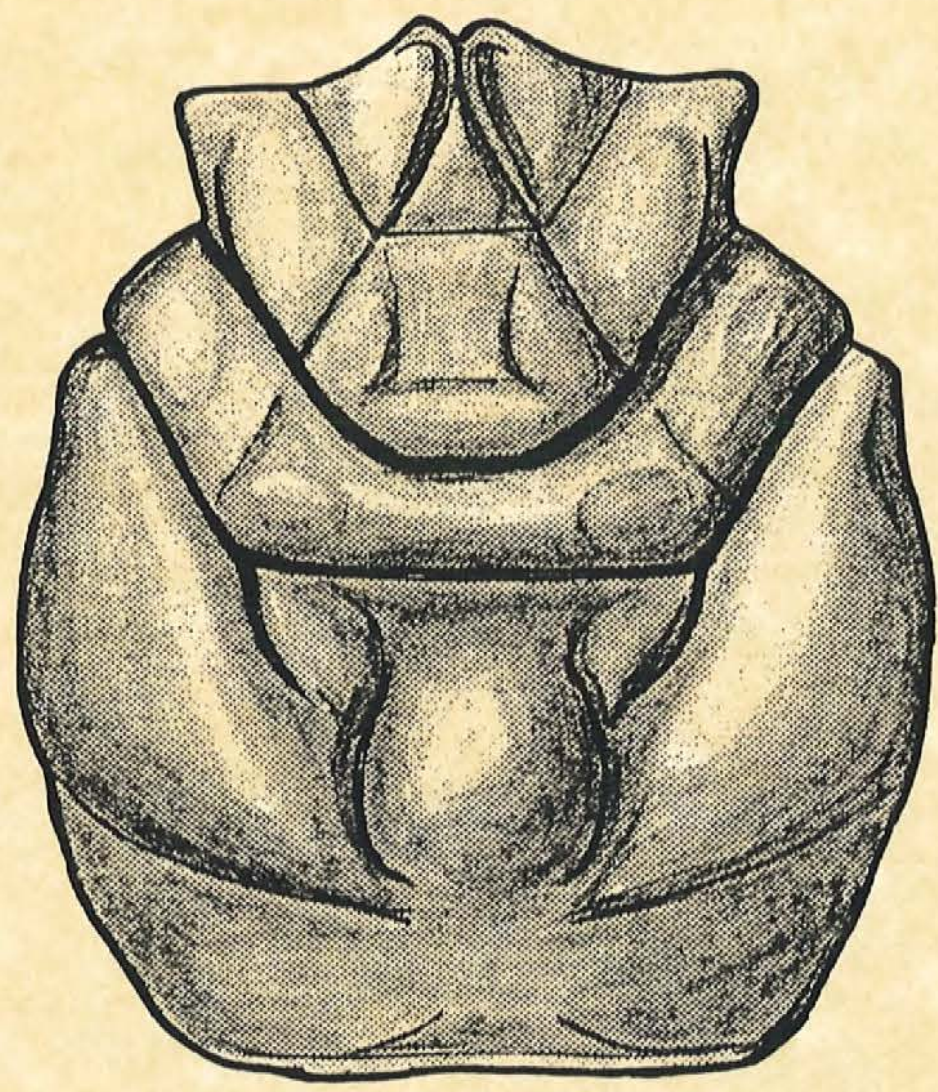

\section{Ekalakia lamberti Bishop}

Upper Cretaceous crab from the Pierre Shale.

Dorsal view of holotype (10.7 mm in length) from Skull Creek. Collected by Marshall Lambert from Carter County, Montana. (G.A. Bishop, 1976, Journal of Paleontology, v. 50, p. 398) Reproduced by permission of the Paleontological Society. 


\title{
THE MARShall LAMBERT SYMIPOSIUM
}

\author{
Pioneer Trails Museum, Bowman, North Dakota \\ June 19 \& 20, 1993
}

\section{BANQUET PROGRAM}

June 19, 1993

$$
\begin{gathered}
\text { 5:30 - Social Hour } \\
\text { 7:00 - Buffet Dinner } \\
\text { Master of Ceremonies }
\end{gathered}
$$

Dean Pearson, Pioneer Trails Museum

In Honor of Marshall Lambert and Presentation of Society of Vertebrate Paleontology Resolution Joseph H. Hartman, Energy \& Environmental Research Center

Comments to Marshall from the Audience

$$
\text { Closing Comments }
$$




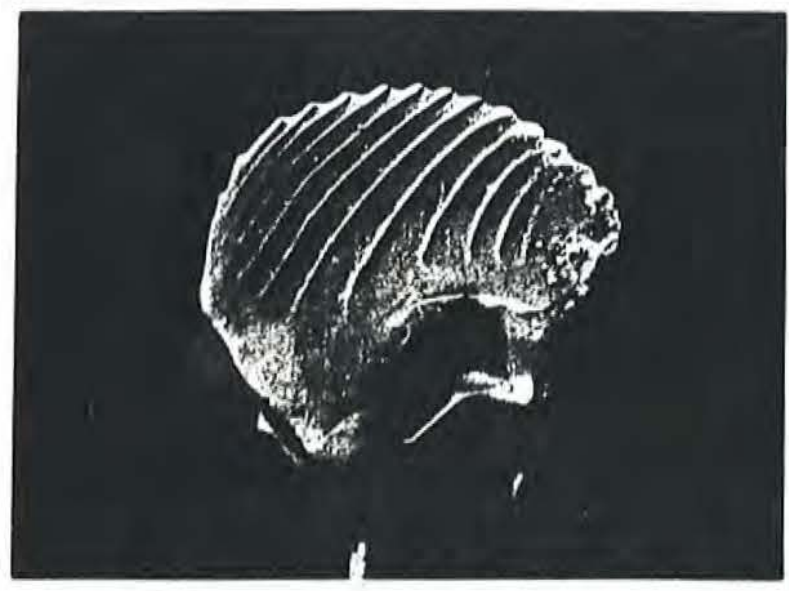

\section{Baiotomeus lamberti Krause}

Paleocene multituberculate from the Tongue River Formation. Buccal view of left $\mathrm{P}_{4}$ of holotype (5.8 $\mathrm{mm}$ in length). Collected by Marshall Lambert at the Medicine Rocks I Locality, Carter County, Montana.

(D.W. Krause, 1987, Journal of Paleontology, v. 61, p. 597) Reproduced by permission of the Paleontological Society. 


\title{
The MarShall LAMBERT SyMPOSIUM
}

\section{IN HONOR OF MARSHALL LAMBERT}

\author{
Joseph H. Hartman \\ Energy \& Environmental Research Center, University of North Dakota, \\ Grand Forks, ND 58202-9018
}

Marshall E. Lambert is well known outside of Ekalaka, Montana. His contributions to paleontology, particularly in regard to vertebrates, have become common knowledge amongst those studying Cretaceous and Tertiary fossils and rocks in the northern Great Plains. The fossils he has provided paleontologists for their study now have a "life" of their own, taking up temporary and sometimes permanent residence in museums and academic collections from coast to coast. But what people remember most about Marshall Lambert is his kind and generous demeanor and his willingness to share his knowledge of his field of study.

Marshall was born and raised in eastern Montana. He was intrigued at an early age by badland terrain and the fossils it contained. He graduated from Carter County High School in 1932. Shortly thereafter, having sold all but his hat and bedroll, Marshall attended Fresno State College (University of California). Although he preferred geology, he was directed by relatives and advisors to forego the earth sciences, as geologists were "starving to death." As a profession, paleontology has never been a discipline for the financially focused person. In 1939, Marshall undertook studies in education at the University of Alaska. He cleaned and prepared Pleistocene vertebrates for Otto Geist of the Frick Laboratories of the American Museum of Natural History. In Alaska, Marshall also worked in placer gold mining operations and, in his spare time, collected fossils that he sent back to the Carter County Museum.

During World War II, Marshall flew B-25 twin-engine bombers in North Africa and ferried multiengine aircraft around the world for the U.S. Army Air Corps. He was later recalled into the U.S. Air Force, and, once again, returned to Alaska, this time to become familiar with heavy equipment operation at the Romanzoff Radar Station.

In 1946, Marshall took a position as the science teacher at the Carter County High School and became the director of the Carter County Museum, a position he holds to the present day. He began his professional paleontological career by preparing dinosaur material in the museum's collections. In 1949, he obtained experience, with C. Bertrand Schultz (University of Nebraska) and Weldon Frankforter (Grand Rapids Public Museum), preparing rhinoceros bones for display in the State Museum at the University of Nebraska, under the direction of preparator Henry Reider. In 1953, upon returning from military duty in Alaska, Marshall began the process of mounting the skeleton of Anatosaurus in the Carter County Museum.

The beginning of Marshall's career in Paleocene mammalian paleontology began in 1956, with the discovery of isolated mammal teeth in the picturesque cross-bedded sandstones of Medicine Rocks State Park. Coincidently, in 1956, Glen Jepsen, a vertebrate paleontologist from Princeton University, visited the Carter County Museum and inquired about Mr. Lambert's knowledge of Paleocene vertebrate fossils. With just a few teeth to show, Marshall began his long association with students of vertebrate paleontology at Princeton University. The roster of 


\section{The MaRShall Lambert Symposium}

acquaintances includes Don Baird (Princeton University), Elwyn Simons (Duke Primate Center), Claude Britt, Jr. (archeologist with the Ohio Department of Parks and Recreation), Ken Rose (Johns Hopkins University), Phil Gingerich (University of Michigan Museum of Paleontology), and Bob Emry (U.S. National Museum of Natural History). As an indication of his desire to enhance his paleontological abilities, in 1968, Marshall took a year's leave of absence to work in the paleontology lab at Princeton. He undertook curation of the mammal teeth he had collected from Medicine Rocks. Marshall later spent the summer at the geology field camp of the Yellowstone Bighorn Research Association (YBRA) south of Red Lodge, Montana.

In 1975, Marshall retired from teaching at the Carter County High School and began the full-time job of constructing the present Carter County Museum facility. This undertaking involved the acquisition of many tons of petrified wood that would form walls in the new building. During this time, in 1976, Marshall was honored, as paleontologists are want to do, by having a fossil species named after him. The first was Ekalakia lamberti Bishop, a crab from the Upper Cretaceous Pierre Shale in Carter County (see p. 29). As with others, Marshall was responsible for the collection of a specimen that would become the namebearer of the species. As time went on, Marshall even more frequently became a source of knowledge on the geology and paleontology in the greater Carter County area. Marshall helped more than one of the symposium contributors, including Ed Belt (Amherst College), Bud Holland (University of North Dakota), Barbara Wehrfritz (University of North Dakota), and me (first at the University of Minnesota and later at the Energy \& Environmental Research Center), with these efforts spanning vertebrate and invertebrate paleontology and general geology. To name a few, Marshall has contributed to the success (or even existence) of projects by Dave Archibald (San Diego State University), Jerry Clark (U.S. Bureau of Land Management), Bill Clemens (University of California at Berkeley), Roger Colton (U.S. Geological Survey), and George Frison (University of Wyoming). In addition to these efforts are the species of mammal fossils he found that bear his name, including the multituberculates Taeniolabis lamberti, named by Nancy Simmons (University of California at Berkeley) (see p. 1), and Baiotomeus lamberti, named by Dave Krause (State University of New York at Stony Brook) (see p. 31).

As is probably typical of many encounters, an example from my own personal experience with Marshall is enlightening. I had just begun my dissertation studies, and, on the advice of others, I wrote Marshall requesting an opportunity to talk to him about fossil mollusks. Over a few days in 1977, I examined museum collections and found a number of specimens of interest. From one locality, Marshall showed me a shoe box of well-preserved shells he had collected circa 1960. He gave me a portion of his sample and directions to locate the site, which I was able to find and sample. The discovery and initial collection of these freshwater shells by Marshall serve as the basis for my contribution to this symposium. This is just one example of many in which a seemingly small contribution was to grow from Marshall E. Lambert's labor of love.

I wish to thank Brice Lambert of the Ekalaka Eagle and Dean Pearson of the Pioneer Trails Museum for providing many of the specifics mentioned in this brief history. Marshall is a very private and modest man; details a historian might like to know will have to wait for another time. 


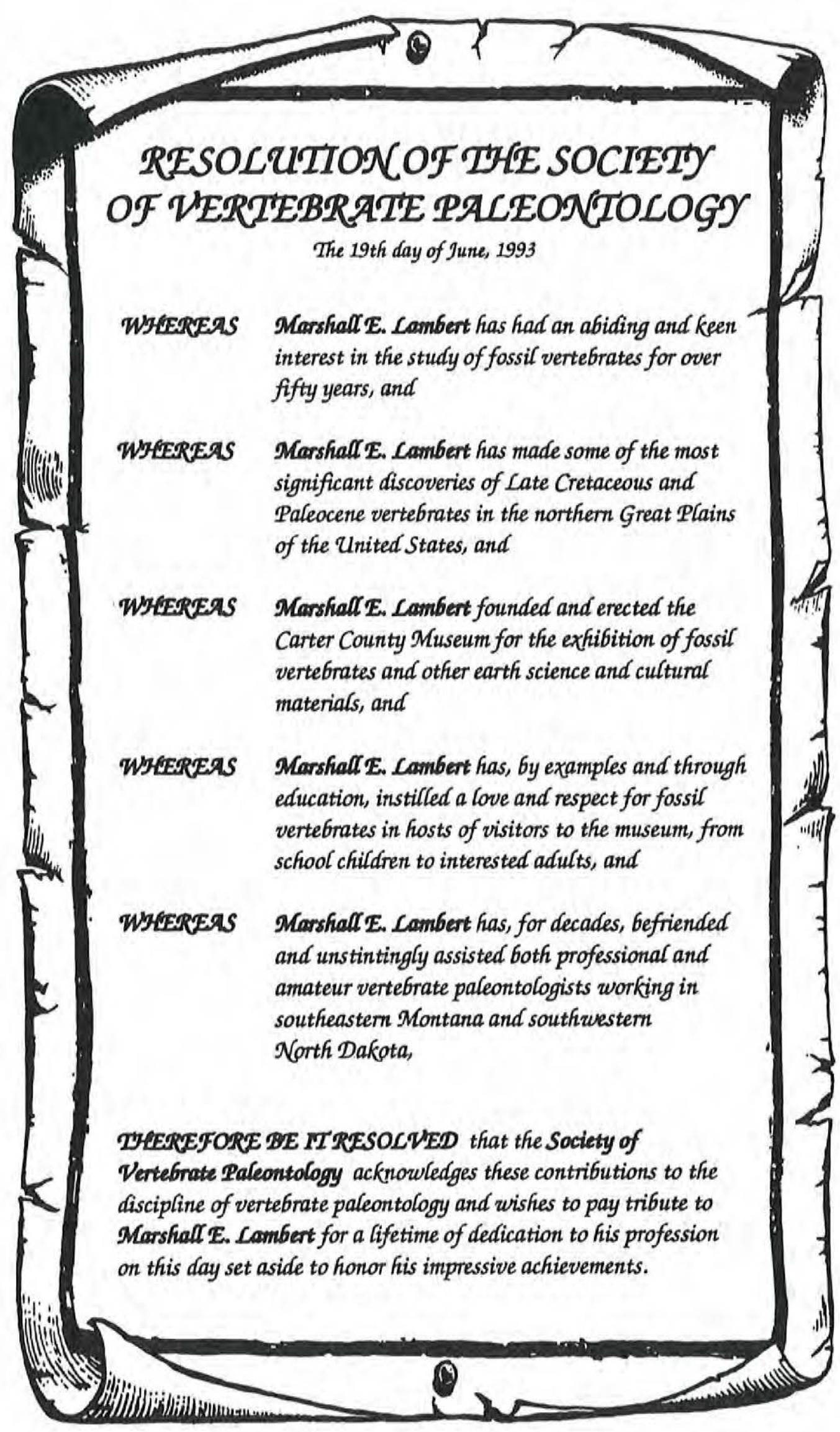


The Marshall LAMBert Symposium Field TriP aNd ROAD LOG

\section{Part III:}

\section{FIELD TRIP AND ROAD LOG}





\title{
FIELD TRIP OF THE UPPER CRETACEOUS AND LOWER TERTIARY GEOLOGY AND PALEONTOLOGY OF EXTREME SOUTHWESTERN NORTH DAKOTA
}

June 20, 1993

\author{
Jointly Sponsored by the \\ North Dakota Geological Society and the \\ Pioneer Trails Museum
}

In conjunction with The Marshall Lambert Symposium

\section{FIELD TRIP ITINERARY}

Trip Leaders (coordinators) - Allen J. Kihm and Dean A. Pearson

Start - Bowman, North Dakota (8:00 a.m. MDT)

Stop 1 - Vertebrate fauna of the Medicine Pole Hills, White River Group, Chadron Formation, Chadronian (uppermost Eocene).

Discussions by Dean Pearson and Ed Murphy.

Stop 2 - Paleobotany and vertebrates from the uppermost Cretaceous Hell Creek Formation of the Mud Buttes area, Bowman County, North Dakota.

Discussions by Kirk Johnson and Dean Pearson.

Stop 3 - The Upper Cretaceous of southwestern North Dakota-The transition from marine to terrestrial environments.

Short stop with discussion by Allen Kihm.

Stop 4 - The Fox Hills-Hell Creek formational contact (Upper Cretaceous).

Short stop with discussion by trip leaders.

Lunch - Box lunch for field trip participants at Bunkhouse in Marmarth.

See W.P.A. historical sketch of Marmarth.

Stop 5 - Paleobotany and the Cretaceous-Tertiary boundary at Pyramid Butte, Hell Creek and Ludlow Formations.

Discussion by Kirk Johnson.

Stop 6 - The Rhame Bed (Paleocene).

Discussion by Barbara Wehrfritz.

End - Return to Bowman (estimated time of arrival 4:00 p.m. MDT).

People participating in the field trip will be expected to drive their own vehicles. We will try to arrange as much car/van/pickup pooling as possible. Much of the drive will be on gravel roads, and, weather and river permitting, we will attempt to ford the Little Missouri River south of Marmarth. 
7

n 


\section{ROAD LOG OF THE UPPER CRETACEOUS AND LOWER TERTIARY GEOLOGY AND PALEONTOLOGY OF EXTREME SOUTHWESTERN NORTH DAKOTA}

\section{ROAD LOG CONTENTS}

\section{Allen J. Kihm}

Road Log: Bowman-Rhame-Medicine Pole Hills-Mud Buttes-Marmarth-RhameBowman.

\section{Dean A. Pearson}

White River Group deposits of the Medicine Pole Hills, Bowman County, North Dakota.

W.P.A. American Guide Project Cedar Creek Anticline.

\section{C.G. Carlson} Medicine Pole Hills Field, Bowman County, North Dakota.

\section{Kirk R. Johnson} The geology and paleobotany of the Hell Creek and lower Fort Union Formation in Slope and Bowman Counties, North Dakota.

\section{Dean A. Pearson} Cretaceous Vertebrate Studies in the Mud Buttes, Bowman County, North Dakota.

Allen J. Kihm

The Upper Cretaceous of southwestern North Dakota-The transition from marine to terrestrial environments.

W.P.A. American Guide Project Marmarth.

W.P.A. American Guide Project Fort Dilts.

W.P.A. American Guide Project The Rhame Community.

Joseph H. Hartman

Teddy Roosevelt up the Little Missouri River.

Joseph H. Hartman

The type areas of the Paleocene Slope Formation and intercalated tongues of the Cannonball Formation, Slope County, North Dakota. 
The Marshall Lambert Symposium FIELD TRIP AND ROAD LOG

\section{ROAD LOG CONTRIBUTORS}

\section{Clarence G. Carlson}

North Dakota Industrial Commission, Oil and Gas Division, 600 East Boulevard Avenue, Bismarck, North Dakota 58505

Joseph H. Hartman

Energy \& Environmental Research Center, P.O. Box 9018, Grand Forks, North Dakota 58202

Kirk R. Johnson

Denver Museum of Natural History, 2001 Colorado Boulevard, Denver, Colorado 80205

Allen J. Kihm

Minot State University, Department of Earth Science, 500 University Avenue West, Minot, North Dakota 58702

Edward C. Murphy

North Dakota Geological Survey, 600 East Boulevard Avenue, Bismarck, North Dakota 58505

\section{Dean A. Pearson}

Pioneer Trails Museum, Department of Paleontology, 100 East 2nd Street, P.O. Box 1044, Bowman, North Dakota 58623

W.P.A. Guide Project

The Bowman County Historical and Genealogical Society has permitted excerpts from the "Guide and History of Bowman \& Slope Counties (American Guide Project), W.P.A." (reprinted 1984) to be used in the road log. The articles were published in the Bowman County Pioneer during the 1930s. In this usage, the authorship and source of the historical information are sometimes not available and the publication is unpaginated. As reproduced here, these historical notes are slightly edited. For similar accounts generated by the WPA Federal Writers Project published by the State Historical Society of North Dakota as "The WPA Guide to 1930s North Dakota" (1990), 376 p. 


\title{
Road Log \\ BOWMAN-RHAME-MEDICINE POLE HILLS- MUD BUTTES-MARMARTH-RHAME-BOWMAN
}

\author{
Allen J. Kihm \\ Department of Earth Science, Minot State University, Minot, ND 58702
}

\section{Introduction}

This road $\log$ is modified from the Day 2 road log developed by Richard D. LeFever, Edward C. Murphy, C.G. Carlson, and Eric Clausen for the North Dakota Geological Society's 1986 field trip. Some of the stops are the same (for convenience) and the stratigraphic framework is the same (by necessity), but the focus is different. This field trip is designed to highlight ongoing research on the fossils of the Bowman-Marmarth area and to place those studies into geologic context. The road log is given in miles to conform with currently available odometers.

Special thanks go to the landowners who have allowed researchers access to their lands to conduct the original work, and we extend our thanks to the following for allowing access to their lands for this field trip:

\author{
Stop 1 - Jeff and Lori Oakland \\ Stop 2 - Bureau of Land Management \\ Stop 3 - Bureau of Land Management and Larry Turbiville \\ Stop 4 - Vernon Miller \\ Stop 5 - Horse Creek Grazing Association \\ Stop 6 - State of North Dakota
}

\section{Road Log}

$\underline{\mathrm{mi}}$

0.0 Gather at the 4-U Restaurant parking lot on the west side of Bowman near the intersection of U.S. highways 12 and 85 (where U.S. 85 turns south). Begin the road log from the intersection by proceeding west on U.S. 12 .

2.5 Exposures on the southwest side of the road are capped by the Rhame bed, which includes a silcrete described by Wehrfritz (1978, see also Wehrfritz this volume) (see Stop 6). The Rhame bed marks the contact of the Slope Formation and the overlying Bullion Creek Formation.

2.9 The exposures in the roadcut on the south side of the road are of the Slope Formation and the exposures on the buttes north of the road are of the lower part of the Bullion Creek Formation. The clinker (North Dakota "scoria") that caps the buttes is correlated with the Harmon lignite. This clinker is a persistent butte-capping unit in the Bowman-Rhame area and can be used as a stratigraphic reference throughout this area. 


\section{The MARShall LAMBert Symposium Field TRIP AND ROAD LOG}

The Harmon lignite bed was named by Leonard and Smith (1909) for exposures along the Little Missouri River along the north edge of T. 138 N., R. 102 W., Billings County, North Dakota, about $61 \mathrm{~km}(38 \mathrm{mi})$ north of Rhame. The correlation of the Harmon lignite to the clinker exposed in this area is generally accepted by relative stratigraphic position, but its identity with the Harmon lignite has not been firmly established.

\subsection{Griffin Elevator.}

12.9 Rhame (see W.P.A. historical sketch of Rhame, this volume); intersection with U.S. 12; turn left (south).

18.1 The oil wells visible on the west side of the road are part of the Coyote Creek Field. This small field was discovered in 1969 and has had a total of nine wells drilled of which eight are producing and one is used for water injection. The producing unit is the Red River Formation (Ordovician) at a depth of approximately $2,000 \mathrm{~m}(6,550 \mathrm{ft})$. Production of the field in 1991 was 69,726 barrels of oil, 257,356 barrels of water, and 2,700 million $\mathrm{m}^{3}\left(94,727\right.$ million $\left.\mathrm{ft}^{3}\right)$ of gas.

20.7 The buttes on the east side of the road are the northern portion of the Medicine Pole Hills and are capped with sandstones of the White River Group.

21.4 Access to Stop 1 is by a rather rough road. To keep our impact on the pastures to a minimum, we will be "truckpooling" from this point into the site.

Stop 1: Medicine Pole Hills locality (NE $1 / 4$ sec. 2, T. 130 N., R. 104 W.). This stop is to discuss the strata of the Eocene Chadron Formation (White River Group) and its contact with the underlying Paleocene Bullion Creek Formation (Fort Union Group) (discussions by Dean Pearson and Ed Murphy). Fossils from the Medicine Pole Hills represent the first significant vertebrate fauna from the Chadron Formation in North Dakota (see abstract and road log contribution by Pearson this volume).

23.0 Koch injection facilities to the west. These facilities serve the unitized portion of the Medicine Pole Hills Field, which is described by Carlson (this volume).

26.4 The road cut here exposes a lignite bed, but on the hill to the west, after we pass by the cut, the coal burned and baked the overlying strata to produce a clinker.

27.0 Intersection with gravel road, turn west.

31.8 T-intersection, turn left (south). The buttes ahead are of the northern end of Mud Buttes. The color change, representing the contact between the Hell Creek Formation and the overlying Ludlow Formation, is clearly visible.

32.4 Road cut. This road cut is approximately at the level of the Hell Creek-Ludlow formational contact, which is better seen at Stop 2. 


\section{The MARShall LAMBERT Symposium FIELd Trip AND ROAD LOG}

32.9 Intersection with gravel road; turn left.

33.6 Stop 2: Mud Buttes area (SW $1 / 4$ sec. 1, SE $1 / 4$ sec. 2, NE $1 / 4$ sec. 11, and NW $1 / 4$ sec. 12, T. 129 N., R. 105 W.); park along the side of the road, but be aware that if there has been any recent moisture, the shoulders of the road may be very soft. The exposures of the Hell Creek Formation in the Mud Buttes in this area have produced both a diverse leaf flora (discussion by Kirk Johnson this volume) and a vertebrate fauna (discussion by Dean Pearson this volume). This is a turnaround location.

34.3 Return to main gravel road and turn left (west).

39.7 Crossing of Fivemile Creek. The exposures on the south and north sides of the road are of the Fox Hills Formation.

41.5 Hard right turn; well battery to the west. The wells in this area are part of the Little Missouri Field. There are two distinct fields. The deeper field, at approximately 2,500 $\mathrm{m}(8,200 \mathrm{ft})$ is the small oil-producing Little Missouri-Red River (Ordovician) Field, which was discovered in 1958. A total of 12 wells were drilled in this field of which eight have been plugged and abandoned and one was shut in (in 1991). The 1991 production figures for the three producing wells are 14,893 barrels of oil, 23,429 barrels of water, and 650 million $\mathrm{m}^{3}\left(22,853\right.$ million $\left.\mathrm{ft}^{3}\right)$ of gas. The shallower field, at a depth of approximately $411 \mathrm{~m}(1,350 \mathrm{ft})$, is in the Cretaceous Eagle Sandstone and was discovered in 1945 . This field produces only gas, with 41 wells in production (plus one in the Eagle/Judith River formational interval). The 1991 figures for these wells show production of more than 5,400 million $\mathrm{m}^{3}\left(190,000\right.$ million $\left.\mathrm{ft}^{3}\right)$ of gas.

42.7 Crossing of Fivemile Creek. The Fox Hills-Hell Creek formational contact can be seen near the top of the exposures northeast of the road. The contact will be visible again from 1.0 to 1.5 miles further north.

45.6 Intersection, turn left (west).

48.4 Descend from the flats onto the floodplain of the Little Missouri River.

48.9 Ford (with luck and low water) the Little Missouri River. In the case of adverse conditions, we will return to U.S. 12 after the Mud Buttes stop and take West River Road south out of Marmarth.

49.3 T-intersection; turn right (north) onto West River Road. The shales of the Pierre Formation are poorly exposed on the west side of the road in bluffs known as Cedar Ridge.

53.6 The Pierre-Fox Hills formational contact is visible on the bluffs to the east. The contact is marked by the color change from dark gray (shales of the Pierre) to light brown (sandstones of the Fox Hills). 


\section{The Marshall LAMBert SyMPOSIUM Field TriP aND ROAD LOG}

53.9 Stop 3: The road cut on the east side of the road is an exposure of the Fox Hills (top of the hill) and the Pierre (at base) Formations (NW $1 / 4 \mathrm{SW}^{1 / 4} \mathrm{sec} .4$ and NE $1 / 4 \mathrm{SE}^{1 / 4} \mathrm{sec} .5$, T. 130 N., R. 106 W.). The contact itself is not well exposed, but it is gradational, representing the transition from the offshore environments (represented by the shales of the Pierre Formation) to the shallower water and coarser sediments of the Trail City Member of the Fox Hills Formation.

61.7 Stop 4: Exposures on the west side of the road include the Fox Hills-Hell Creek formational contact $\left(\mathrm{W}^{1 / 2} \mathrm{NW}^{1 / 4}\right.$ sec. 33, T. $132 \mathrm{~N}$., R. $106 \mathrm{~W}$.). The contact is drawn at the change from the cross-bedded sandstones of the Colgate Sandstone Member to the claystones of the Hell Creek Formation, which represents a change from marine shoreline deposition (of the Colgate Sandstone) to the terrestrial-fluvial deposition of the Hell Creek Formation. The Timber Lake Member of the Fox Hills Formation is exposed in the drainage further to the south.

63.5 Exposures from here to Marmarth are of the Hell Creek Formation.

67.2 Crossing of Little Beaver Creek.

67.6 Intersection with paved surface of U.S. 12; turn right (east) toward Marmarth.

67.9 Entering Marmarth, follow the lead car to the "Bunkhouse."

\section{Lunch}

0.0 Return to U.S. 12 and travel west.

0.9 Intersection with gravel road (U.S. Forest Service 783) and old highway 16; turn right.

6.0 Possible wet crossing of South Butte Creek.

6.8 Fork in the road; stay to the right on the main track. Pretty Butte, which is directly ahead, is capped by a clinker that has been correlated with the T Cross lignite, which marks the contact between the Ludlow Formation and overlying Slope Formation.

10.0 Crossing of North Butte Creek.

10.8 Stop 5: The butte to the northeast has been called Pyramid Butte and contains exposures of the uppermost Hell Creek Formation and the lowermost Ludlow Formation. These strata have been sampled for pollen and paleomagnetic analysis and preserve the Cretaceous-Tertiary boundary (as defined by the pollen). The rocks have also produced a macrofossil flora (discussion by Kirk Johnson). Return to U.S. 12.

20.9 Intersection of old highway 16 and U.S. 12; turn left and proceed through Marmarth.

22.1 Crossing of the Little Missouri River. 


\section{The Marshall LAMBert Symposium Field TRIP AND ROAD LOG}

30.3 Turnoff to Fort Dilts (see W.P.A. historical sketch of Fort Dilts, this volume).

34.9 Stop 6: The Rhame bed is exposed along the south side of the road in the borrow ditch (boundary of SE1/4 NE $1 / 4$ sec. 21 and SW $1 / 4 \mathrm{NW}^{1 / 4} \mathrm{sec} .22$, T. $132 \mathrm{~N}$., R. $104 \mathrm{~W}$.). Post Office Butte is located immediately to the southwest. Barbara Wehrfritz will discuss occurrence of silcrete deposits and the Rhame bed.

36.3 Rhame.

49.2 Bowman. End of road log.

\section{References}

Carlson, C.G., 1993, Medicine Pole Hills Field, Bowman County, North Dakota: North Dakota Geological Society, The Marshall E. Lambert Symposium Contributions and Road Log, Pioneer Trails Museum, June 19-20, 1993, Bowman, North Dakota (this volume).

Harland, W.B, Armstrong, R.L., Cox, A.V., Craig, L.E., Smith, A.G., and Smith, D.G., 1990, A geologic time scale 1989. Cambridge, Cambridge University Press, 263 p.

Johnson, K.R., The geology and paleobotany of the Hell Creek and lower Fort Union Formation in Slope and Bowman Counties, North Dakota: North Dakota Geological Society, The Marshall E. Lambert Symposium Contributions and Road Log, Pioneer Trails Museum, June 19-20, 1993, Bowman, North Dakota (this volume).

Leonard, A.G., and Smith, C.D., 1909, The Sentinel Butte Lignite Field, North Dakota and Montana: U.S. Geological Survey, Bulletin 341, p. 15-35.

Pearson, D.A., 1993, Cretaceous vertebrate studies in the Mud Buttes area, Bowman County, North Dakota: North Dakota Geological Society, The Marshall E. Lambert Symposium Contributions and Road Log, Pioneer Trails Museum, June 19-20, 1993, Bowman, North Dakota (this volume).

Pearson, D.A., 1993, The Medicine Pole Hills Local Fauna-The first diverse Chadronian (latest Eocene)-age fauna from North Dakota: North Dakota Geological Society, The Marshall E. Lambert Symposium Contributions and Road Log, Pioneer Trails Museum, June 19-20, 1993, Bowman, North Dakota (this volume).

Pearson, D.A., 1993, White River Group deposits of the Medicine Pole Hills, Bowman County, North Dakota: North Dakota Geological Society, The Marshall E. Lambert Symposium Contributions and Road Log, Pioneer Trails Museum, June 19-20, 1993, Bowman, North Dakota (this volume).

Swisher, C.C., III, and Prothero, D.R., 1990, Single-Crystal ${ }^{40} \mathrm{Ar} /{ }^{39} \mathrm{AR}$ dating of the Eocene-Oligocene transition in North America: Science, v. 249 (4970), p. 760-762.

Wehrfritz, B.D., 1978, The Rhame bed (Slope Formation, Paleocene) a silcrete and deep-weathering profile, in southwestern North Dakota [M.S. thesis]: Grand Forks, University of North Dakota, $158 \mathrm{p}$.

Wehrfritz, B.D., 1993, Silcrete: A Distinctive rock type related to K/T boundary events: North Dakota Geological Society, The Marshall E. Lambert Symposium Contributions and Road Log, Pioneer Trails Museum, June 19-20, 1993, Bowman, North Dakota (this volume), 
The MARShall LAMBERT SYMPOSIUM FIELD TRIP AND ROAD LOG

Figure 1

Southwestern North Dakota Field Trip Road Log

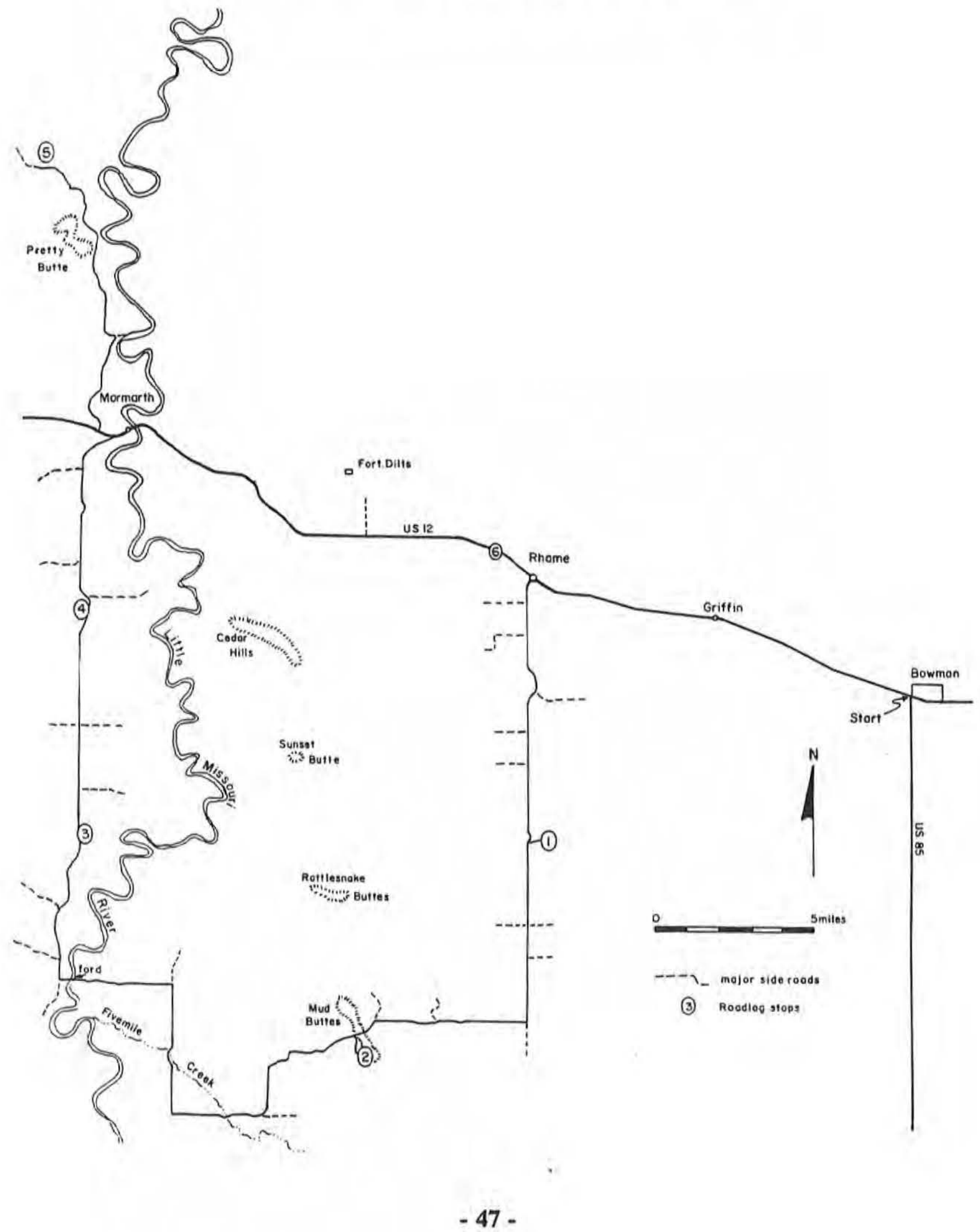


THE MARShall LAMBert Symposium Field TRIP AND ROAD LOG

Figure 2

Geologic Column of Southwestern North Dakota

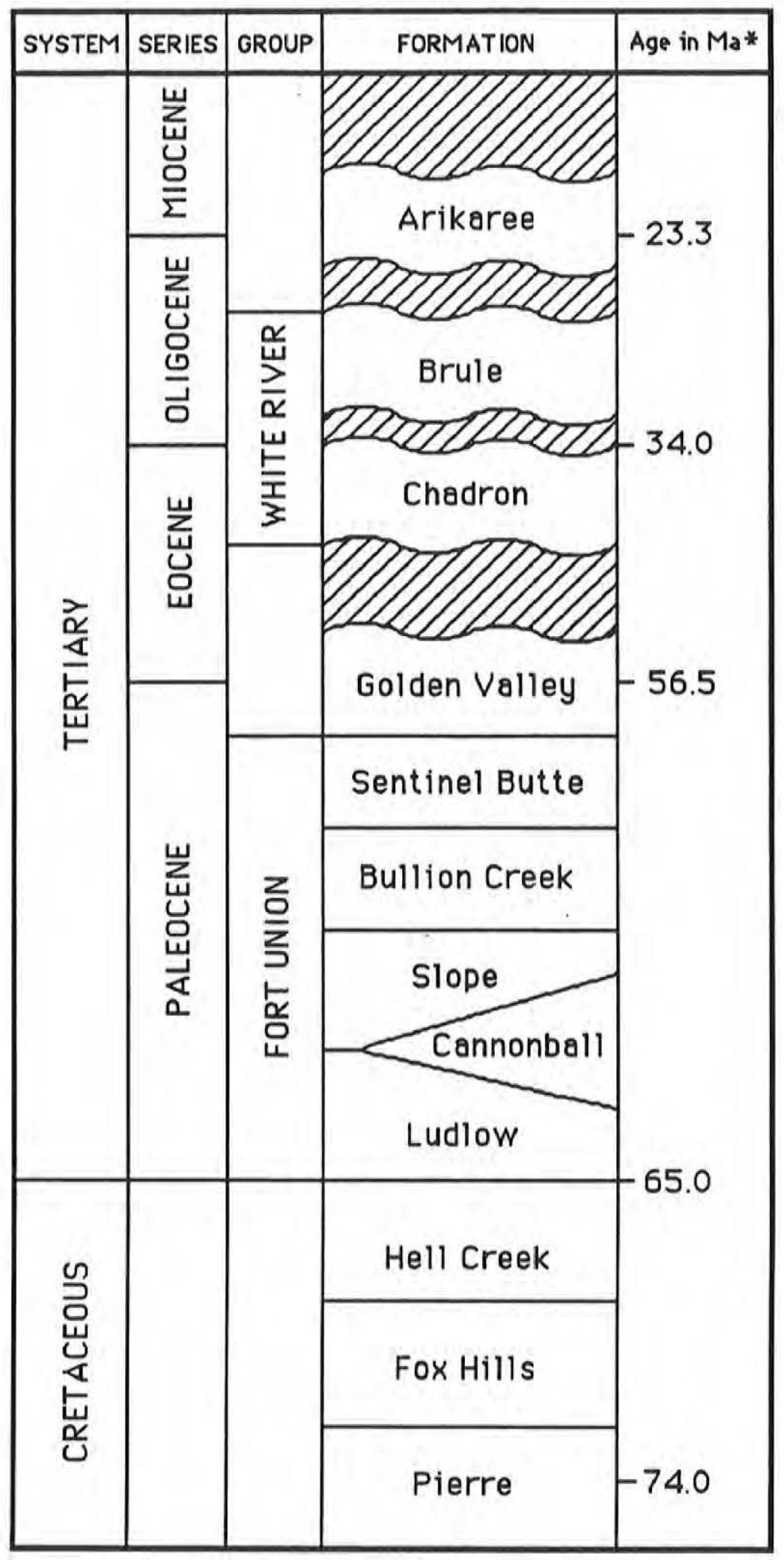

* Ma = Megaannum, one million years of time. All dates are from Harland and others (1990) except the date of the Eocene-Oligocene boundary. This date is based upon work by Swisher and Prothero (1990). 


\title{
The MARShall LAMBert Symposium ROAd LOG CONTRIBUTIONS
}

\section{WHITE RIVER GROUP DEPOSITS OF THE MEDICINE POLE HILLS, BOWMAN COUNTY, NORTH DAKOTA}

\author{
Dean A. Pearson \\ Department of Paleontology, Pioneer Trails Museum, Bowman, ND 58623
}

New studies on the Chadron Formation of the White River Group, currently underway between the Pioneer Trails Museum and the North Dakota Geological Survey, have identified a Chadronian-age deposit in the Medicine Pole Hills, located seven miles south of the town of Rhame, in central Bowman County. The locality, consisting of a number of sites, is referred to as the Medicine Pole Hills Local Fauna.

Fossils from the Medicine Pole Hills were first noted in 1921 by the State Geologist A.G. Leonard during reconnaissance work in the area (Leonard, 1922). Leonard reported the remains of an unidentified titanothere (brontotheriid). No subsequent study has been done in the Medicine Pole Hills until the start of our project in 1989. To date, these deposits have produced a number of taxa rarely observed from the Chadronian, including catfish, crocodilians, lizards, and early tapirs (see Pearson, 1993, for faunal list).

Strata of the Chadron Formation are found atop the scattered buttes in the area. Section thicknesses range anywhere from a few centimeters (inches) up to $5 \mathrm{~m}(17 \mathrm{ft}$ ). The deposits consist mainly of yellowish orange sandstones and conglomerates, which are disconformable with the underlying strata of the Paleocene-age Bullion Creek Formation. The uppermost preserved unit of the Bullion Creek Formation is a well-cemented sandstone that forms either ledges or caprock on the buttes. Figure 1 illustrates a typical section representing the transition between the Bullion Creek and Chadron Formations and the location of the fossiliferous horizons.

\section{References}

Leonard, A.G., 1922, The White River Formation in North Dakota: Quarterly Journal of the University of North Dakota, v. 12, no. 3, p. 116-128.

Lilligraven, J.A., 1970, Stratigraphy, structure, and vertebrate fossils of the Oligocene Brule Formation, Slim Buttes, northwestern South Dakota: Geological Society of America, Bulletin, v. 81, p. 831-850.

Pearson, D.A., 1993, The Medicine Pole Hills Local Fauna-The first diverse Chadronian (latest Eocene)-age fauna from North Dakota: North Dakota Geological Society, The Marshall E. Lambert Symposium Contributions and Road Log, Pioneer Trails Museum, June 19-20, 1993, Bowman, North Dakota. 
Figure 1

\section{Geologic Section of the Medicine Pole Hills Locality}

Section 117-Oakland

$\mathrm{NE}^{1 / 4} \mathrm{SW}^{1 / 4} \mathrm{NE}^{1 / 4} \mathrm{sec} .2$, T. 130 N., R. $104 \mathrm{~W}$.

Section 117 is $6.63 \mathrm{~m}$ in height.

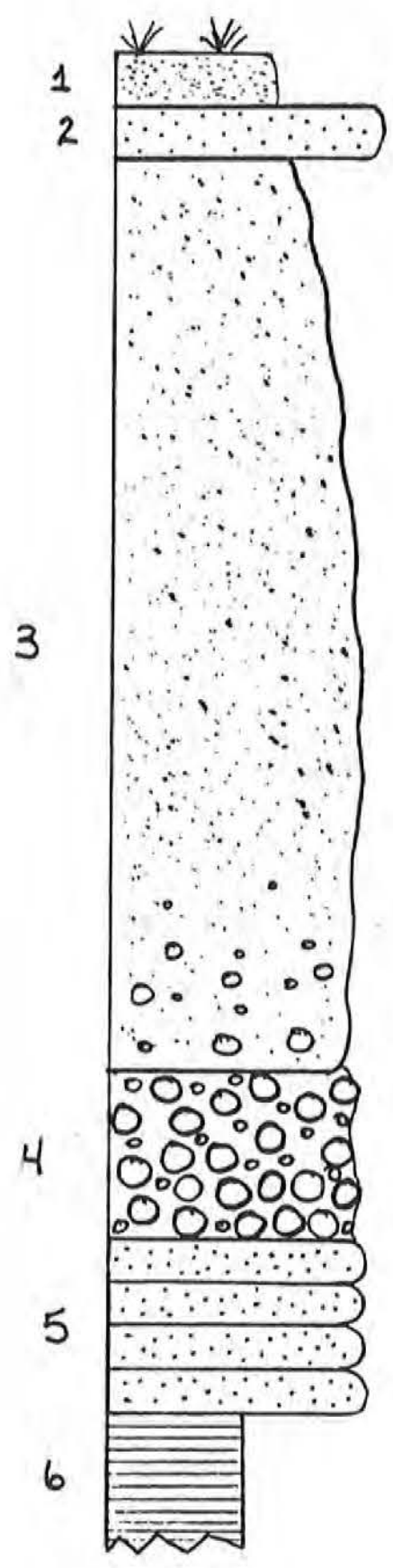

Grass Cover

Unit 1: Poorly cemented quartzose sandstone.

Unit 2: Cemented quartzose sandstone, locally present on some buttes.

Unit 3: Poorly cemented quartzose sandstone, which probably represent the "golden sands" lithology of Lilligraven (1970). Most fossils are found in Units 1-3.

Unit 4: Coarse pebble to cobble conglomerate at base of Chadron Formation. Worn fossil fragments have been found in this unit.

Unit 5: Cemented, ledge-forming quartzose sandstone of the Bullion Creek Formation.

Unit 6: Siltstones and mudstones. 


\title{
THE MARShall LAMbert Symposium RoAd Log CONTRIBUTIONS
}

\section{THE CEDAR CREEK ANTICLINE}

\author{
W.P.A. American Guide Project (1930s) \\ (reprinted with permission*)
}

Drilling for oil began on September 1, 1935 on the Little Beaver Dome, 990 feet from the Bowman county-Montana line. This deep test well was financed by the Montana-Dakota Utilities Co., [which] has been operating in the field for some time. The Little Beaver Dome is part of the Cedar Creek Anticline which extends from eastern Montana into southwest North Dakota. There are approximately 25,000 acres in western Bowman county supposed to be productive.

It has been supposed for some years that oil would be found on this anticline at very deep horizons but the diversity of land ownership and holdings delayed deep drilling. In 1932 the Montana-Dakota Utilities Co,, began working out a unit plan of operations. The location for the deep test was decided upon after extensive geological survey. The well was drilled on the NE corner of the NW quarter of section 17, Township 4 N, Range 62 E., in Fallon county, Montana. Oil was struck at a depth of 6,700 feet on Tuesday April 21, 1936. The Fallon County Times in an extra edition on that date said that the oil field is one of the largest gas fields in the world and that oil in vast commercial quantities is to be had. Tests of the crude oil showed "a product apparently high in gasoline and kerosene content extremely light as to body, blacker in color and with a smell somewhat different than that commonly associated with mid-continent crude." It could not be ascertained whether or not this test was representative of what the well may yicld.

A boom is expected at Marmarth as a result of the strike, as this town is only about 16 miles from the well. Conservative estimates of the well's production places it at 800 to 1400 barrels per day. The oil prospects is the great topic of interest in the locality at present but it is by no means the only one. Ever since 1913 natural gas has been constantly increasing in quantity and use from this field. The first well was drilled here for natural gas in 1913 by the Midwest Oil Co. They drilled to a depth of 2,800 feet on the Gas City Dome near Glendive, Mont., which is at the extreme north end of [the] anticline. They discovered gas at a depth of 750 feet but no oil was found and the well was capped.

In 1915 the Eastern Montana Oil and Gas Co.. drilled more wells and began furnishing gas to Glendive. Gas was discovered near Baker, Mont., in 1915, at 800 feet. Baker has had gas supplied since that time for both domestic and industrial use. This includes gas supplied to a carbon black plant which brought the total consumption per day at Baker up to 3 and 4 million cubic feet. Many productive wells were drilled in the following years on these and other domes of the anticline. Much speculation in leases and Government permits was earried on in the region. In 1926 the Montana-Dakota Power Company entered the field. Since that time progress has been rapid throughout the more productive parts of the area. The company acquired leases on the Cabin Creek and other domes and purchased equipment and franchises of other companies.

The gas supply to Glendive had been abandoned some years before on account of poor management and lack of technical knowledge. The Montana-Dakota Power Co., started this service again in August 1926 from the Cabin Creek Dome 40 miles away. The same company had the fuel piped to Miles City from this dome, a distance of 75 miles and had service functioning in Oetober, 1927. By November the service had been extended to Terry. About the same time the pipe line reached Marmarth, N.D., the first place in North Dakota to have gas from this field. By the fall of 1928 two hundred and twenty-five miles of main gas line had been built to the Black Hills in South Dakota, furnishing gas to Rapid City, Lead, Deadwood, Sturgis, Spearfish, and Belle Fourche. The total open flow capacity of all wells connected to the system at the end of the 1928 season was in excess of 150 million cubic feet of gas daily. Further activities brought gas to Bismarck from the Cedar Creek Anticline field in 1929 and to Bowman in 1930. It is also furnished to other cities in the western part of our state.

This is one of the largest gas producing areas in the U.S., having more than 110,000 acres of land where gas may be obtained. At present 153 producing gas wells have an open flow of 900,000,000 cubic feet per day. "Two-thirds of these wells are capped under pressure awaiting a market.["] To the present time no drilling for oil or gas has been started in the 25,000 acres of productive area in Bowman county although the oil well is within 990 feet of the border.

* See Road $\log$ Contributors for citation and explanation. 


\title{
The Marshall Lambert Symposium RoAd LOG CONTRIBUtions
}

\section{MEDICINE POLE HILLS FIELD, BOWMAN COUNTY, NORTH DAKOTA}

\author{
C.G. Carlson \\ North Dakota Industrial Commission, Oil and Gas Division, \\ Bismarck, ND 58501
}

Bowman County currently produces about 110,000 barrels of oil per month, with about 35,000 of that from the Medicine Pole Hills Field (Figure 1). The oil is produced from the Red River Formation (Ordovician), which is about $152.4 \mathrm{~m}$ (500 ft) thick and is reached at depths of around $2900 \mathrm{~m}(9,500 \mathrm{ft})$. The upper portion of the Red River Formation consists of cyclical deposits of carbonates and anhydrites, with porosity developed in the carbonates referred to as A, B, C, and D zones (Figure 2). Porosity development within each cycle is quite variable, and this accumulation is a combination of structure and stratigraphic change.

The Medicine Pole Hills Field was discovered in 1967 while drilling the A.J. Hodges-Clarence Hestekin No. 1 well (NE $1 / 4$ NE $1 / 4$ sec. 15, T. 130 N., R. 104 W.), which was completed at an initial potential of 46 barrels of oil and 5 barrels of water per day. The pool was gradually developed on a 130-ha (320-acre) spacing pattern with most of the development of the field occurring in the ' 70 s. There were some 65 -ha (160-acre) infill wells among the 29 producing wells drilled. There are currently 22 producing wells in the field.

Koch Industries unitized a portion of the Medicine Pole Hills Field in 1985 for the purposes of enhanced recovery through an air injection-thermal recovery project. Details of the operations are of a proprietary nature, but the basic principles are as shown on Koch's Exhibit 14 (Figure 3). Air is injected into the reservoir, and since the reservoir temperature is about $93^{\circ} \mathrm{C}\left(200^{\circ} \mathrm{F}\right)$, there is ignition. The project was approved in 1985 , but before injection facilities were operational, the decline in the price of oil in 1986 delayed the project. Three infill wells were completed in 1985 and 1986 resulting in the 1986 increase in production (Figure 4). Air injection began with three injection wells in October 1987, and additional wells were added in June and September of 1988. Some productive response was seen in April 1988, but the significant response was seen in the Medicine Pole Hills Unit 22-24 well, which was producing at rates of 3,600 to 4,200 barrels of oil per month through July. In the following months, the production was $5,711,6,245,7,616$, and 7,933 barrels of oil, reaching a secondary peak of 8,056 barrels of oil in January 1989. Two additional infill wells were completed in December 1991, accounting for the production increase seen in late 1991 (Figure 4). Koch's enhanced recovery project continues to be successful as two additional injection wells were completed in late 1992 . 
Figure 1

Location Map for the Medicine Poles Unit and Field

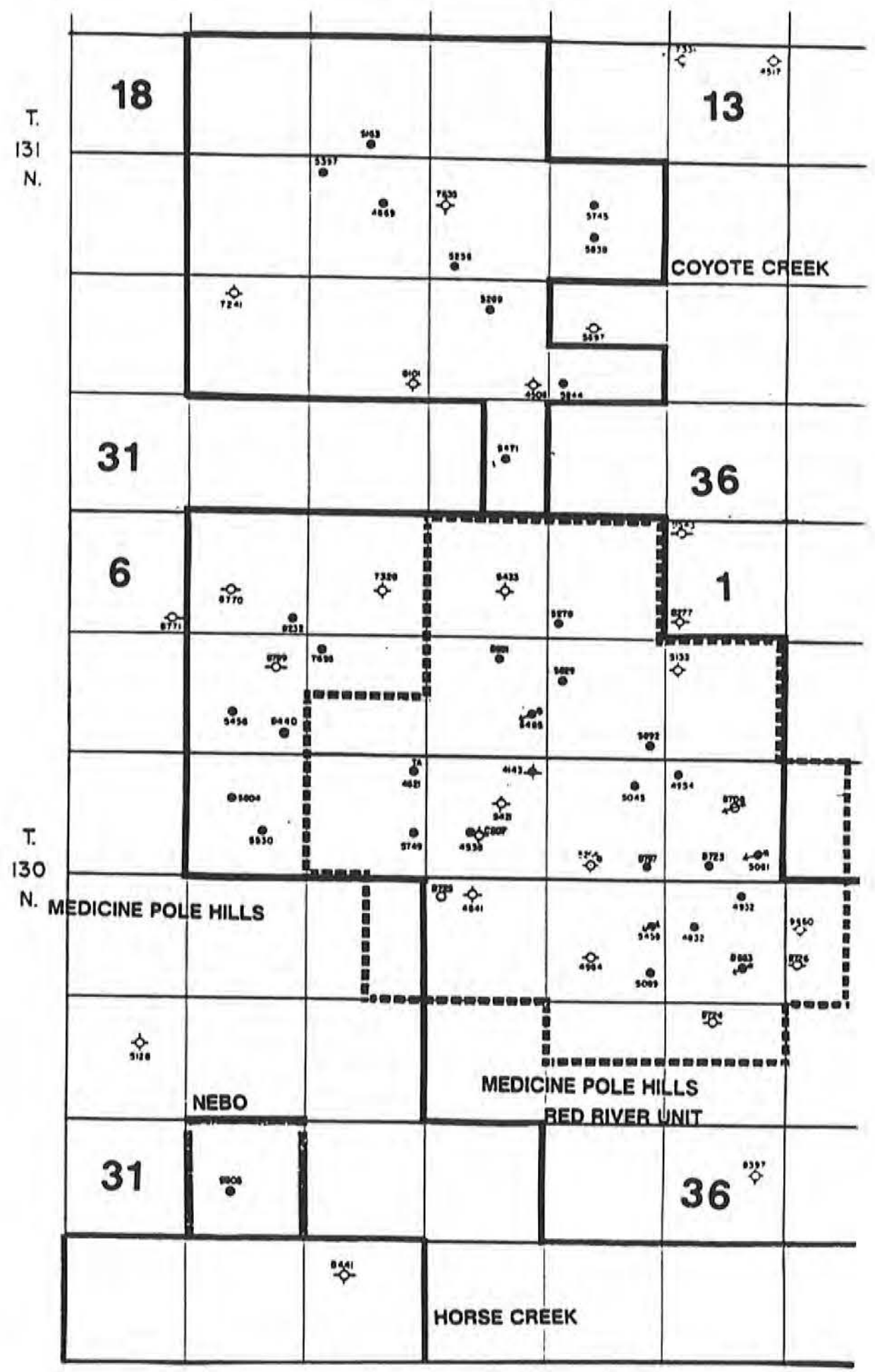


The Marshall LAMBert Symposium RoAd Log Contributions

Figure 2

Gamma Ray-Neutron Log of the Upper Portion of the Red River Formation in the Medicine Pole Hills Field

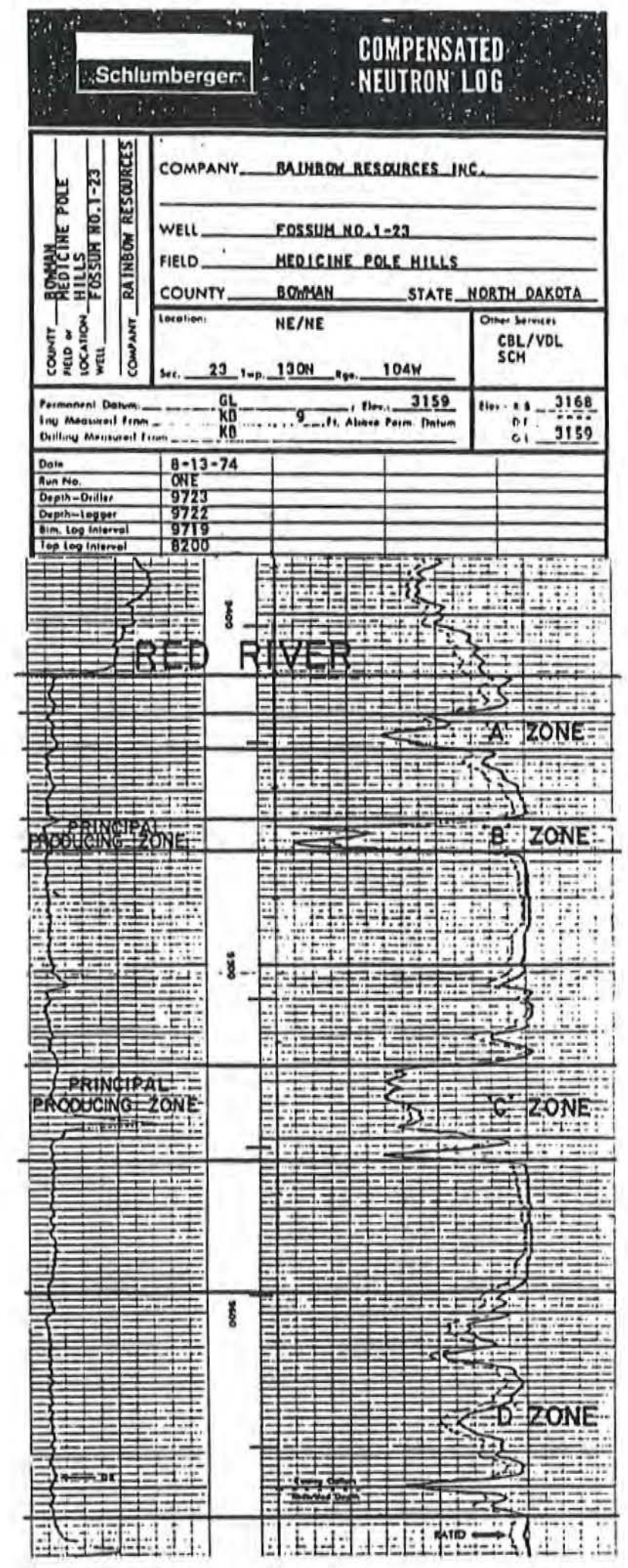


The Marshall Lambert Symposium RoAd Log ConTributions

Figure 3

Schematic Diagram of the Air Injection-Thermal Recovery Process
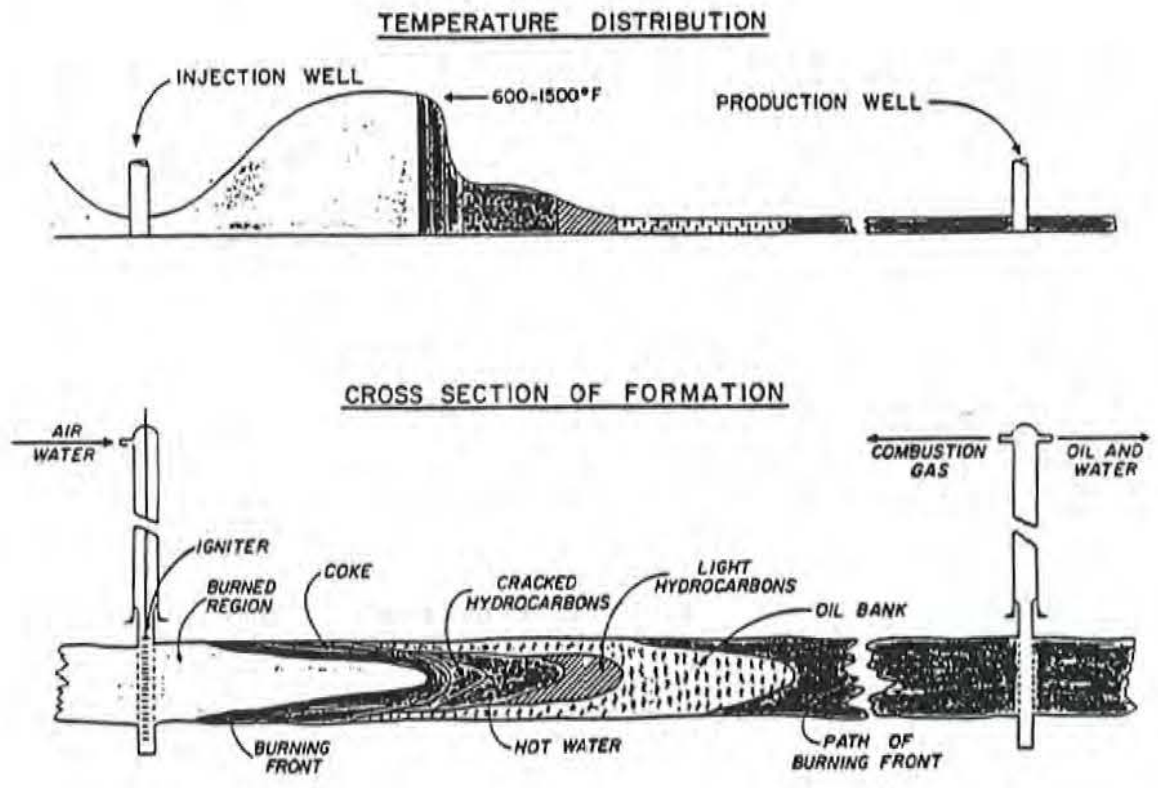

Figure 4

Graph of Production and Injection for the Medicine Pole Hills-Red River Unit

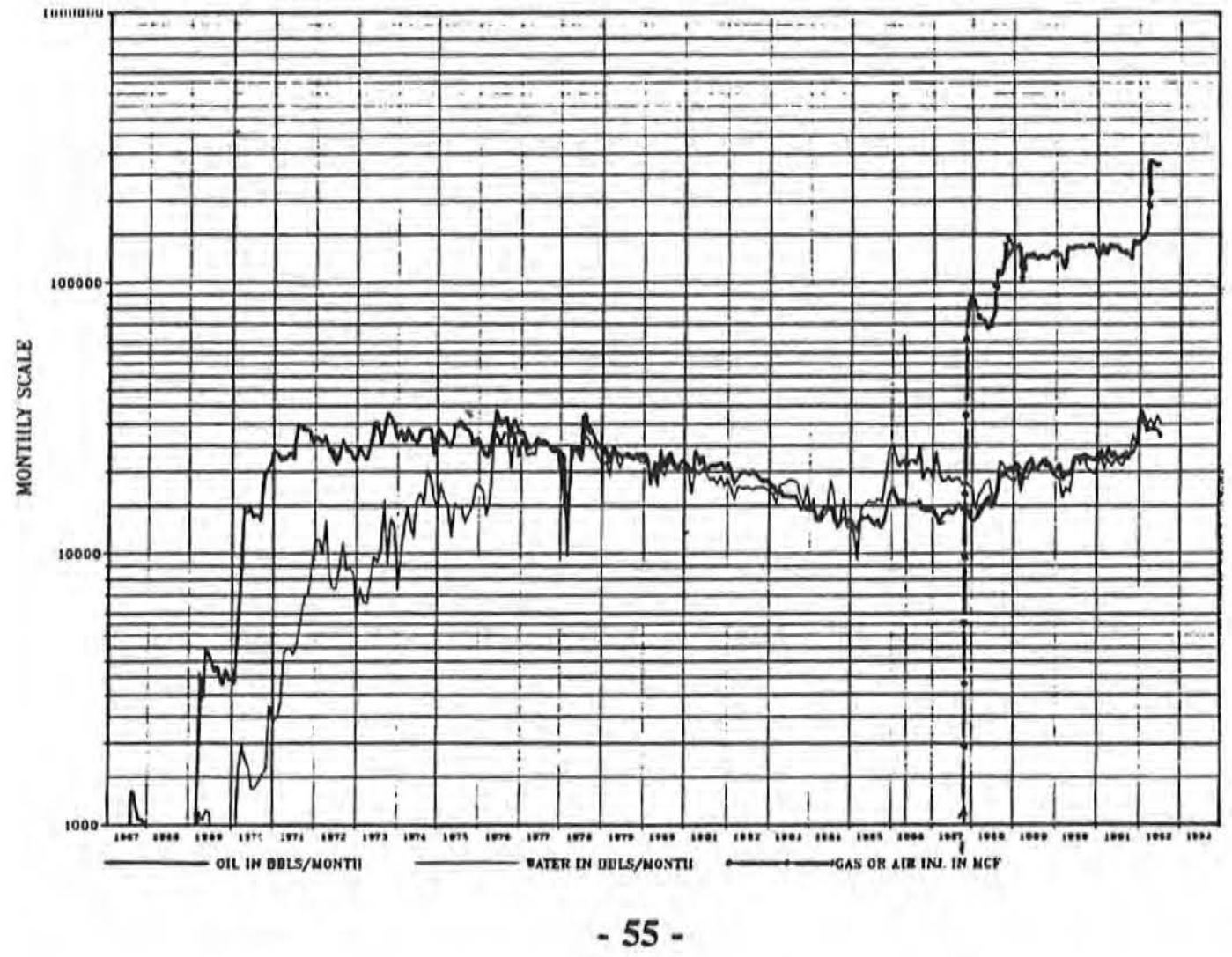




\title{
The Marshall Lambert Symposium RoAd LOG CONTRIBUTIONS
}

\author{
THE GEOLOGY AND PALEOBOTANY OF THE \\ HELL CREEK AND LOWER FORT UNION FORMATIONS \\ IN SLOPE AND BOWMAN COUNTIES, NORTH DAKOTA
}

\author{
Kirk R. Johnson \\ Department of Earth Sciences, Denver Museum of Natural History, Denver, CO 80205
}

\section{Introduction}

In westernmost North Dakota, the Little Missouri River has eroded a series of badlands that extends from South Dakota north to the Missouri River. The river has cut across the NW-SE-trending Cedar Creek anticline, the structural feature that forms the boundary of the Powder River and Williston Basins, and exposed an increasingly younger sequence of rocks to the north. The formations in southwest North Dakota, from the core of the anticline near the North Dakota-South Dakota border in order of ascending position, are the Pierre Shale (Maastrichtian marine shale), the Fox Hills Formation (Maastrichtian marginal marine sediments), the Hell Creek Formation (Maastrichtian fluvial sediments), and the Ludlow Member of the Fort Union Formation (Paleocene fluvial and fluviodeltaic sediments with intercalated marine sediments of the Cannonball Member of the Fort Union Formation) (Figure 1). These deposits record the Late Cretaceous regression of the Pierre seaway, the Cretaceous-Tertiary $(\mathrm{K} / \mathrm{T})$ boundary, and the early Paleocene transgression of the Cannonball seaway.

The badlands of the Little Missouri River around Marmarth in Slope and Bowman Counties, North Dakota, provide superb exposures of the Hell Creek Formation and the overlying Ludlow Member of the Fort Union Formation. This area is important because it represents some of the most extensive fossiliferous exposures of the Cretaceous/Tertiary boundary section known anywhere in the world. Both fossil plants (leaves and pollen) and vertebrates occur in the same rocks and provide a superb record of latest Cretaceous and earliest Tertiary terrestrial life. Data from these rocks support the theory of a major terrestrial extinction of plants and animals at the $\mathrm{K} / \mathrm{T}$ boundary. The $\mathrm{K} / \mathrm{T}$ boundary section at Pyramid Butte, north of Marmarth, contains anomalously high concentrations of iridium and shocked minerals, the physical evidence of an extraterrestrial impact.

\section{Geology and Age}

The Hell Creek Formation near Marmarth is a 110-m-thick sequence of flat-lying root-bioturbated mudstone beds intercalated with lenticular sandstone and muddy sandstone (Hares, 1928; Frye, 1969; Moore, 1976; Fastovsky, 1987) (Figure 2). The mudstone units contain numerous root traces, slickensides, horizons, and ped structures and have been interpreted as poorly drained floodplain paleosols (Fastovsky \& McSweeney, 1987). The lenticular deposits are composed of large-scale lateral accretion units, flat-laminated mudstones, or cross-bedded sandstones and are interpreted, respectively, as channel point bars, oxbow lakes, and channel thalwegs. Coal and carbonaceous shale are rare but present in the Hell Creek. The Hell Creek is known for its vertebrate (especially dinosaurian) fauna, and the Hell Creek beds near Marmarth contain a diverse Lancian vertebrate fauna (Sheehan and others, 1991). 


\section{The MARShall LAMBERT SYMPOSIUM ROAD LOG CONTRIBUTIONS}

The Ludlow Member of the Fort Union Formation is composed of flat-laminated mudstone beds, lignite, and tabular and lenticular sand bodies. These have been interpreted as ponds, swamps, crevasse splays, and meandering and distributary channels (Moore, 1976; Belt and others, 1984; Fastovsky, 1987). Approximately $80 \mathrm{~m}$ above the base of the Ludlow Member there are two marine beds that contain a brackish-water invertebrate fauna and represent the easternmost extent of the Paleocene Cannonball transgression (Brown, 1962). The North Dakota Geological Survey recognizes this part of the section as the Slope Formation (see Hartman article, this volume). The Ludlow Member is generally more deeply weathered than the Hell Creek Formation and, as a result, usually supports vegetation, allowing the units to be readily distinguished.

The contact of the Hell Creek and Fort Union Formations is placed at the base of the first laterally continuous lignite above the typical Hell Creek deposits. This lignite, when present, is generally 10-140 cm thick (Figure 3). When the lignite is missing, the base of the Fort Union Formation is placed at the contact of the underlying smectite-rich, "popcorn-weathering" grey mudstone typical of the Hell Creek and the overlying carbonaceous shale, flat-laminated yellow mudstone, or yellow sandstone typical of the Ludlow Member. In general, the Hell Creek-Fort Union transition represents a change from predominantly subaerially exposed soils to submerged sediments. This apparent increase in base level may have been caused by the initiation of the Cannonball transgression or by increased basin subsidence.

The $\mathrm{K} / \mathrm{T}$ boundary in the northern Great Plains was traditionally placed using the "Brown formula" (Brown, 1962) by which the boundary was located at the first continuous lignite above the highest dinosaur fossils. Although this technique still has rough field applicability, it represented a mixture of lithostratigraphy and biostratigraphy and it has been supplanted by the use of palynostratigraphy. The palynologically defined $\mathrm{K} / \mathrm{T}$ boundary is based on the disappearance of palynomorphs of the Wodehouseia spinata Assemblage Zone of Nichols and others (1982) (Figure 3).

A number of techniques have been used to correlate the Marmarth section with other classic Upper Cretaceous and Lower Paleocene sections. A lithostratigraphic framework of over 40 sections was measured and physically correlated (Figures 1,2). A series of magnetostratigraphic sections were measured and sampled in 1988 and resampled in 1992 (Johnson and others, 1990). The K/T boundary near Marmarth occurs in a zone of reversed polarity interpreted to be Polarity Chron 29R. The remainder of the Hell Creek Formation lies in a zone of normal polarity which is probably $\mathrm{C} 30 \mathrm{~N}$, but may include part of $\mathrm{C} 31 \mathrm{~N}$. This indicates that the Hell Creek Formation in the Marmarth area represents the last 2-3 million years of the Cretaceous. The palynology of these rocks is being studied by D. Nichols of the U.S. Geological Survey in Denver. The Hell Creek palynomorphs represent the late Maastrichtian Wodehouseia spinata Assemblage Zone, and those from the Ludlow Member represent the Paleocene pollen zone P1. Vertebrates are under study at the Milwaukee Public Museum and at the University of California at Berkeley. Mammals from the Hell Creek part of the section are typical Lancian forms (Sheehan and others, 1991), and rare specimens from the Ludlow Member suggest the presence of both the Puercan and Torrejonian stages (D. Krause, pers. comm., 1989). The base of the Marmarth terrestrial sequence rests on the Baculites baculus 


\section{The Marshall LAMbert Symposium RoAd Log CONTRIBUtions}

Zone of the Pierre shale (Bishop, 1973), thus permitting correlation with the established marine invertebrate zonation.

\section{Paleobotany}

The deposits around Marmarth have long been known to contain fossil plants, but previous work in this area has resulted in the discovery of only a few localities and some small collections (Corbin, 1938; Brown, 1939; Frye, 1969). However, these studies did show that this area had the potential to produce latest Cretaceous floras, which, for a variety of reasons, are not found in abundance elsewhere in the northern Great Plains. Since 1981, over 12,000 specimens representing more than 250 plant species have been collected from 102 closely spaced localities that span nearly 200 meters of section from the top of the Fox Hills Formation to the top of the Ludlow Member of the Fort Union Formation (Johnson, 1989 and subsequent work) (Figures 1 and 2). As a result, the Marmarth section is the most thoroughly collected terminal Cretaceous megafloral sequence anywhere in the world.

The megafloral record at Marmarth has been divided into three Cretaceous zones and one Paleocene zone that have been designated HC I, HC II, HC III, and FU I (Johnson, 1989, 1992) (Figure 4). Both HC I and HC II are further divided into two subzones. These zones and subzones can be readily recognized in the field because they are primarily defined by their floral dominants rather than by rare accessory taxa. The subzones are taxonomically distinct but are given subzone status because of their restricted vertical range. The significance of this zonation is that it documents considerable floral change throughout the last 2-3 million years of the Cretaceous and a major floral extinction at the $\mathrm{K} / \mathrm{T}$ boundary.

\section{The Mud Buttes Area (Field Trip Stop 2)}

The Mud Buttes area is a large natural amphitheater located in sections 1, 2, 11, and 12, T. 129 N. R. 105 W., Bowman County, North Dakota (Mud Buttes 7.5-minute Quadrangle). The land is managed by the Bureau of Land Management. The Mud Buttes area contains a wealth of paleontological remains. Exposed in this amphitheater are approximately the uppermost 30 meters of the Hell Creek Formation and the lowermost 50 meters of the Fort Union Formation. Dinosaur fossils are common in the Hell Creek Formation in this area as are plant fossils. The K/T boundary here occurs at the base of a thin carbonaceous shale. This boundary has not been sampled for iridium or shocked minerals. Dinosaur bones have been found within 3 meters of this boundary. A major Cretaceous leaf locality (KJ88102= DMNH428) is located 15 meters below the boundary in a channel deposit composed of massive rooted fine sand. This locality represents megaflora zone HCIII and is one of the most diverse Late Cretaceous floras known, with over 50 different leaf species represented. The dominant species are Dombeyopsis trivialis, a member of the Laurales (modern relatives are avocados and cinnamon); "Cissus" marginatus, a trifoliately compound member of the Platanales (modern relatives are the sycamores); "Liriodendron" laramiense, a very distinct two-lobed member of the Magnoliales (modern relative is the tulip poplar tree); and Amesoneuron sp., a palm. Several Paleocene leaf localities occur in the Ludlow Member of the Fort Union Formation in this area. 


\section{The MARShall LAMbert Symposium RoAD LOG CONTRIBUTIONS}

\section{Pyramid Butte Section (Field Trip Stop 6)}

Pyramid Butte is located just north of Highway 16, 9 miles north of Marmarth and 2 miles north of Pretty Butte in the SW $1 / 4$ NE$^{1 / 4}$ sec. 15, T. 134 N. R. 106 W., Slope County, North Dakota (Pretty Butte 7.5-minute Quadrangle). The land is owned by the Horse Creek Grazing Association, and permission should be obtained before visiting the site. The name Pyramid Butte is informal and does not appear on any map. The Pyramid Butte section is composed of approximately the top 25 meters of the Hell Creek Formation and the basal 40 meters of the Fort Union Formation. Dinosaur material is rare but present in the Hell Creek Formation at this site, and a complete Cretaceous turtle was collected there in 1992. Fossil leaf localities representing zones HCIIa, HCIIb, and FUI are present at this site. At Pyramid Butte, the $\mathrm{K} / \mathrm{T}$ boundary occurs at the top of the $90-\mathrm{cm}$-thick basal Fort Union lignite and is marked by the coincidence of an iridium anomaly, shocked mineral grains, and palynological extinctions (Johnson et al., 1989) (Figure 3). The iridium and shocked mineral grains occur in a 2-3-cmthick dark gray mudstone immediately above the top of the lignite. This mudstone is overlain by a lenticular fine-grained sandstone that is thought to be a crevasse splay channel. Spiral arthropod? burrows perforate the dark gray mudstone and the top few $\mathrm{cm}$ of the lignite. These burrows are filled with the fine sand and their presence indicates a minor hiatus at the base of the sandstone. Neither the typical $\mathrm{K} / \mathrm{T}$ boundary clay layer nor a fern spore anomaly are present at Pyramid Butte. A superb Paleocene (FUI) leaf locality is located only $10 \mathrm{~cm}$ above the K/T boundary.

\section{References Cited}

Belt, E.S., Flores, R.M., Warwick, P.D., Conway, K.M., Johnson, K.R., and Waskowitz, R.S., 1984, Relationship of fluviodeltaic facies to coal deposition in the lower Fort Union Formation (Palaeocene), south-western North Dakota, in Sedimentology of coal and coal-bearing sequences, Rahmani, R.A., and Flores, R.M., eds., International Association of Sedimentologists Special Publication v. 7, p. 177-195.

Bishop, G.A., 1973, Geology, stratigraphy, and biostratigraphy of the north end of Cedar Creek Anticline, Dawson County, Montana: Montana Bureau of Mines and Geology, Special Publication 61.

Brown, R.W., 1939, Fossil plants from the Colgate Member of the Fox Hills Sandstone and adjacent strata: U.S. Geological Survey, Professional Paper 189-I, p. 239-275.

Brown, R.W., 1962, Paleocene flora of the Rocky Mountains and Great Plains. U.S. Geological Survey, Professional Paper 375, 119 p.

Corbin, R.S. 1938, Stratigraphy and paleontology of the Pierre, Fox Hills, and Lance Formations in southwestern North Dakota [B.A. thesis]: New Haven, Princeton University.

Fastovsky, D.E., and McSweeney, K., 1987, Paleosols spanning the Cretaceous-Paleogene transition, eastern Montana and western North Dakota: Geological Society of America, Bulletin, v. 99, p. 66-77.

Fastovsky, D.E., 1987, Paleoenvironments of vertebrate-bearing strata during the Cretaceous-Paleogene transition, eastern Montana and western North Dakota: Palaios, v. 2, p. 282-295. 


\section{The Marshall Lambert Symposium RoAd Log Contributions}

Frye, C.I., 1969, Stratigraphy of the Hell Creek Formation in North Dakota: North Dakota Geological Survey, Bulletin 54, 65 p.

Hares, C.J., 1928, Geology and lignite resources of the Marmarth field, southwestern North Dakota: U.S. Geological Survey, Bulletin 776, 110 p.

Hartman, 1993, The type area of the Paleocene Slope Formation and intercalated tongues of the Cannonball Formation, Slope County, North Dakota: North Dakota Geological Society, The Marshall E. Lambert Symposium Contributions and Road Log, Pioneer Trails Museum, June 19-20, 1993, Bowman, North Dakota (this volume).

Johnson, K.R., 1989, A high-resolution megafloral biostratigraphy spanning the Cretaceous-Tertiary boundary in the Northern Great Plains [Ph.D. thesis]: New Haven, Yale University, $556 \mathrm{p}$.

Johnson, K.R., Nichols, D.J., Attrep, M., Jr., and Orth, C.J., 1989, High-resolution leaf-fossil record spanning the Cretaceous/Tertiary boundary: Nature, v. 340, p. 708-711.

Johnson, K.R., Nichols, D.J., Tauxe, L., and Clark, D., 1990, Floral zonation and magnetostratigraphy of the Hell Creek (late Maastrichtian) and lower Fort Union (early Paleocene) Formations, North Dakota: Geological Society of America, Abstracts with Program, v. 22, p. 323.

Johnson, K.R., and Hickey, L.J., 1991, Megafloral change across the Cretaceous-Tertiary boundary in the northern Great Plains and Rocky Mountains, USA: Geological Society of America, Special Paper 247, p. 433-444.

Johnson, K.R., 1992, Leaf-fossil evidence for extensive floral extinction at the Cretaceous-Tertiary boundary, North Dakota, USA: Cretaceous Research, v. 13, p. 91-117.

Moore, W., 1976, The stratigraphy and environments of the Cretaceous Hell Creek Formation (reconnaissance) and the Paleocene Ludlow Formation (detailed), southwestern North Dakota: North Dakota Geological Survey, Report of Investigations 56, p. 1-40.

Nichols, D.J., Jacobson, S.R., and Tschudy, R.H., 1982, Cretaceous palynomorph biozones for the central northern Rocky Mountain Region of the United States, in Geologic studies of the Cordillera thrust belt, Powers, R.B., ed., p. 721-734.

Sheehan, P.M., Fastovsky, D.E., Hoffmann, R.G., Berghaus, C.B., and Gabriel, D.L., 1991, Sudden extinction of the Dinosaurs: Latest cretaceous, Upper Great Plains, U.S.A.: Science, v. 254 , p. $835-839$.

\section{Figure Explanations}

Figure 1. Geologic map of the Marmarth area showing all megafloral localities and the outcrop area of the Pierre Shale (Kp), Fox Hills Formation (Kfh), the Hell Creek Formation (Khc), and the Ludlow Member of the Fort Union Formation (Tful) on the eastern flank of the Cedar Creek anticline. Each of the reference sections are shown with their megafloral localities listed in stratigraphic order. Listed from north to south: Pyramid Butte (Field Trip Stop 6), River Section, Bobcat Butte, Sunset Butte, and Mud Butte (Field Trip Stop 2).

Figure 2. Stratigraphic framework of the Hell Creek and Fort Union Formations in the Marmarth area showing selected measured sections for each of the reference areas. Megafloral (leaf) localities with stratigraphic position error bars, dinosaur localities, and megafloral zone boundaries are plotted. The Cretaceous-Tertiary boundary is plotted as $90 \mathrm{~cm}$ above the Hell 


\section{The MARShall LAMbert SyMPosium RoAd Log CONTRIBUTIONS}

Creek-Fort Union contact, as it is at Pyramid Butte, but it occurs below the contact at Sunset Butte and Mud Butte.

Figure 3. Distribution and relative abundances of iridium and the most common palynomorphs (pollen and spore types) in the 1.9-m-thick Cretaceous-Tertiary boundary section at Pyramid Butte, North Dakota. Explanation: Khc-Hell Creek Formation, Tfu-Fort Union Formation (Ludlow Member); histogram shows iridium (Ir) concentrations in parts per billion measured in continuous 10 -cm-interval samples and the maximum anomaly from additional samples at smaller intervals; peak Ir anomaly is coincident with shocked mineral occurrence and disappearance of characteristic Upper Cretaceous palynomorphs; vertical lines show ranges of palynomorphs within sampled intervals; dotted lines extend ranges on basis of very rare, nontypical (possibly reworked) occurrences. Palynomorphs are grouped by taxonomic category: bryophytes and pteridophytes, 1-3; gymnosperms, 4-6; angiosperms, 7-30. The taxa are 1-Laevigatosporites spp., 2-Stereisporites spp., 3-Osmundacidites sp., 4-Taxodiaceaepollenites hiatus, 5-cf. Glyptostrobus sp., 6-Ephedra multipartita, 7-Arecipites tenuiexinous, 8-Triporopollenites spp., 9-Ulmoideipites spp., 10-Kurtzipites trispissatus, 11-Momipites inaequalis, 12-Tricolpites parvistriatus, 13-Wodehouseia spinata, 14-Proteacidites spp., 15-Libopollis jarzenii, 16-Liliacidites complexus, 17-Myrtipites granulatus, 18-K. circularis, 19 Aquilapollenites n. sp., 20-A. quadrilobus, 21-Cranwellia rumseyensis, 22- T. microreticulatus, 23-Orbiculapollis lucidus, 24-T. hians/parvus, 25-Ericaceoipollenites rallus, 26-A. delicatus var. collaris, 27.-Leptopecopites pocockii, 28-A. reticulatus, 29-Pandaniidites typicus, 30-Syncolporites minimus.

Figure 4. Selected dominant and accessory taxa from each of the megafloral (fossil leaf) zones of the Hell Creek and Fort Union Formations near Marmarth. Illustrated taxa are (from left to right) FUI: Platanus raynoldsii (FU16), "Populus" nebrascensis (FU7), Dicotylophyllum anomalum (FU29), Paranymphaea crassifolia (FU1); HCIII: "Liriodendron" laramiense (HC166), "Cissus" marginata (HC106), "Dryophyllum" tenneseensis (HC44), Dombeyopsis trivialis (HC105), Paranymphaea hastata (HC111); HCIlb, "Vitis" stantonii (HC14, HC108); HCIIa: aff. Rhamnaceae (HC62), Platanophyllum montanum (HC57), "Dryophyllum" subfalcatum (HC49); HCIb: HC84, HC80, HC81, HC92; HCIa: "Celastrus" taurenensis (HC94), "Dryophyllum" subfalcatum (HC49), "Ficus" artocarpoides (HC86). 
Figure 1

Geology and Fossil Megafloral Localities, Little Missouri River Badlands, near Marmarth, Slope and Bowman Counties, North Dakota

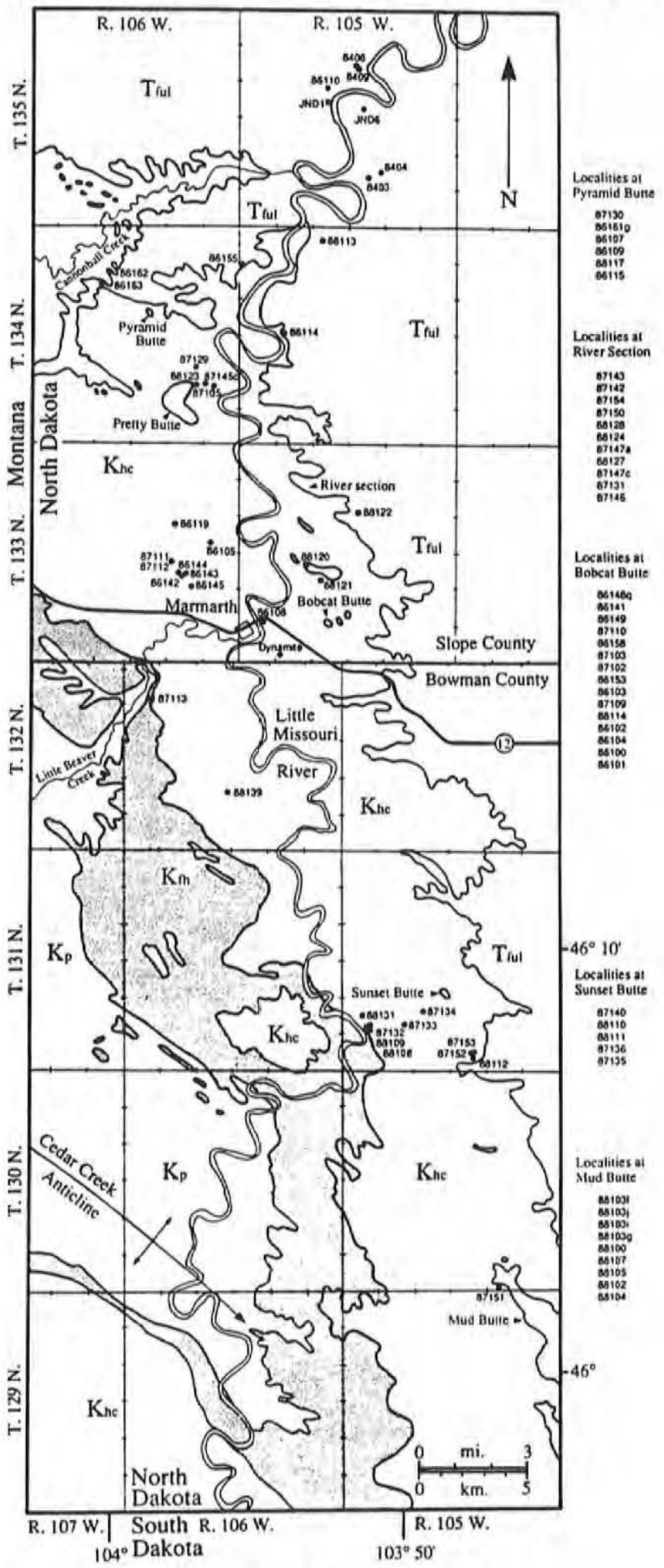




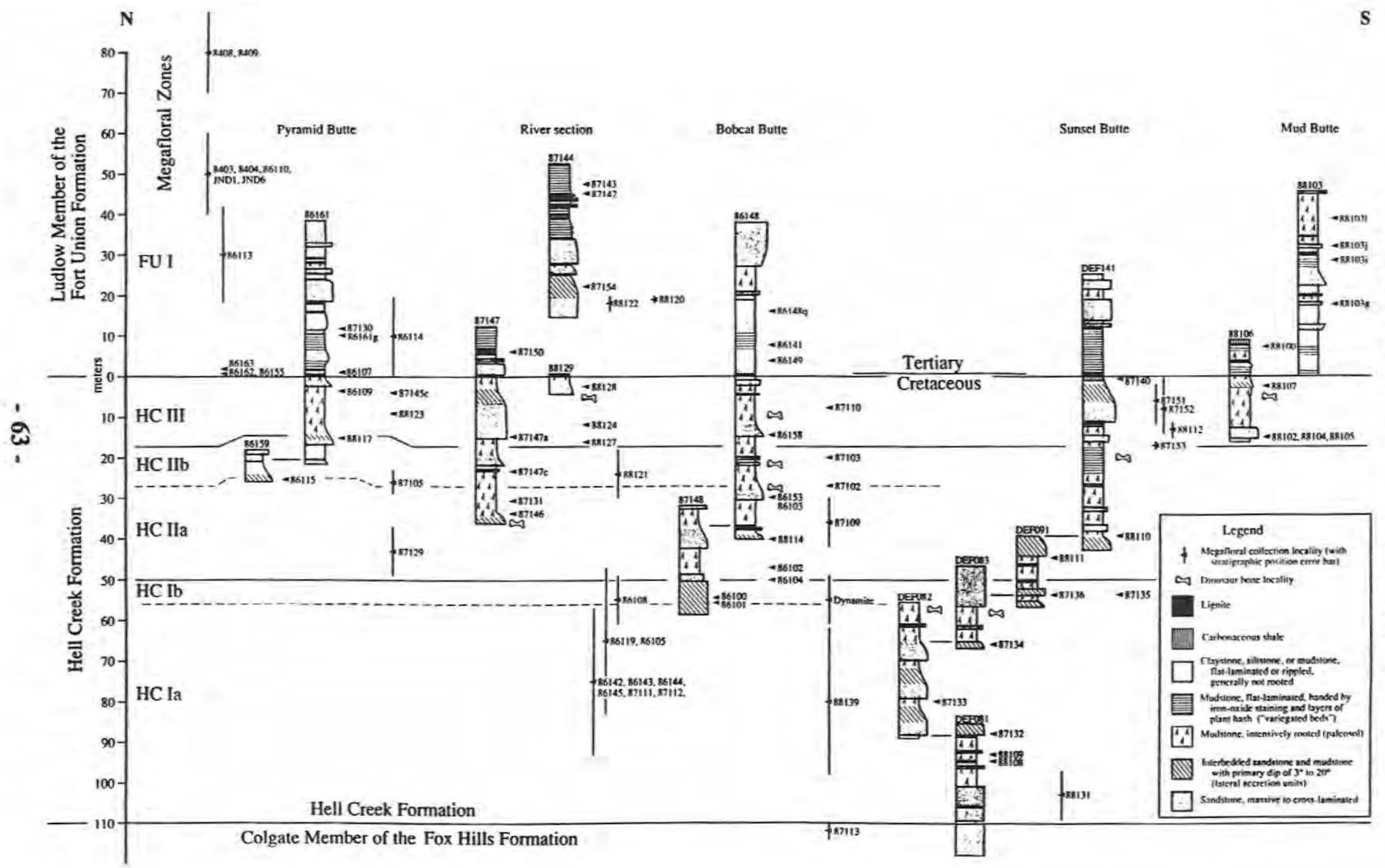




\section{Palynomorphs}

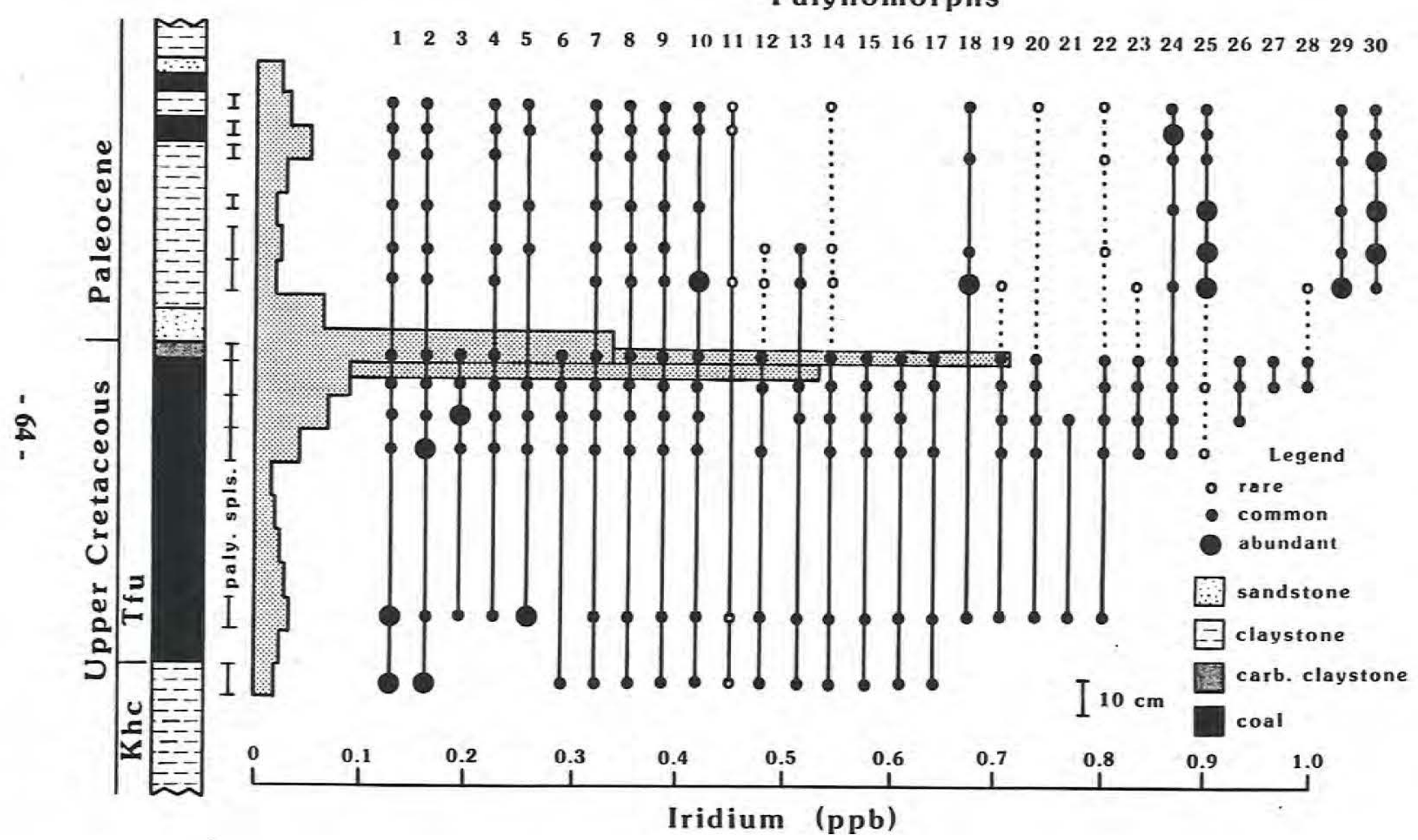


THE MARShall LAMbert Symposium RoAd LOG CONTRIBUTIONS

Figure 4

Megafloral Zonation Across the Cretaceous-Tertiary Boundary

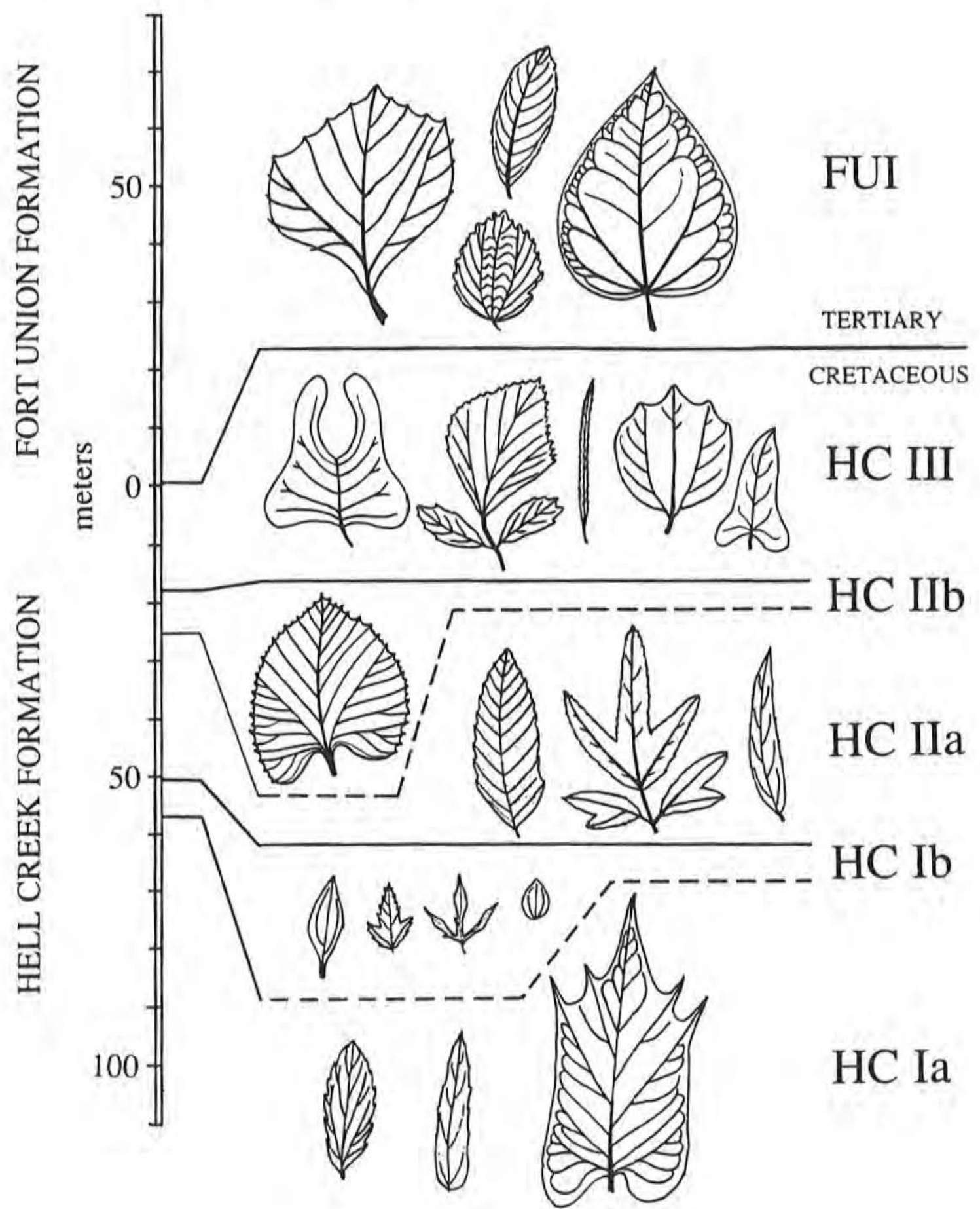




\title{
The Marshall Lambert Symposium ROAd Log CONTRibutions
}

\section{CRETACEOUS VERTEBRATE STUDIES IN THE MUD BUTTES AREA, BOWMAN COUNTY, NORTH DAKOTA}

\author{
Dean A. Pearson \\ Department of Paleontology, Pioneer Trails Museum, Bowman, ND 58623
}

During the 1987-1988 field seasons, vertebrate and plant studies were undertaken in the strata of the uppermost Cretaceous Hell Creek Formation in the Mud Buttes area in the $\mathrm{E}^{1 / 2} \mathrm{sec}$. 2 and the $\mathrm{N} 1 / 2$ sec. 11, T. 129 N., R. 105 W., Bowman County, North Dakota. As a result of these efforts, 58 vertebrate and 5 leaf localities were discovered and sampled. In addition, five geologic sections were measured to place the localities stratigraphically and to determine depositional relationships between the sites.

The study area preserves only the uppermost $15 \mathrm{~m}(49 \mathrm{ft})$ of the Hell Creek Formation, which is overlain by the Paleocene Ludlow Formation. The Cretaceous-Tertiary $(\mathrm{K} / \mathrm{T})$ boundary was recognized in the Mud Buttes section on the basis of megafloral (Johnson, 1989; Johnson and Hickey, 1990) and palynological (Nichols in Johnson, 1989; Nichols and Fleming, 1990; Nichols in Johnson, 1992) studies. All leaf megafloral localities from the Hell Creek Formation in the Mud Buttes area produced specimens from the uppermost Cretaceous HCIII zone (Johnson, 1989). Palynologic studies delimited the K/T boundary on the basis of the Wodehouseia spinata Assemblage Zone. In addition, paleomagnetic studies by David Clark (see Johnson, 1989) indicate that Chron 29R includes the K/T boundary as recognized in the Mud Buttes section. In addition, vertebrate studies by the writer determined the stratigraphically highest occurrence of dinosaur material to be $4.7 \mathrm{~m}$ below the base of the Ludlow Formation.

All vertebrate material found in the Mud Buttes area is indicative of the uppermost Cretaceous (Breithaupt, 1982; Bryant, 1989; Carpenter, 1979). Of the 58 vertebrate sites found in this study area, 25 have produced more than a single specimen. These 25 sites were collected by comprehensive surface picking and produced 1308 specimens. The Mud Buttes vertebrate faunal represents 17 orders, 33 families, and 44 genera.

Once delimited, the lithic changes noted in the faunal transition between Cretaceous and Tertiary strata were correlated throughout the study area. Figure 1 is a composite stratigraphic section that ties together a number of the sites in the Mud Buttes study area.

\section{References}

Breithaupt, B.H., 1982, Paleontology and paleoecology of the Lance Formation (Maastrichtian), east flank of the Rock Springs Uplift, Sweetwater County, Wyoming: University of Wyoming, Contributions to Geology, v. 21, no. 2, p. 123-151.

Bryant, L.J., 1989, Non-dinosaurian lower vertebrates, across the Cretaceous-Tertiary boundary in N.E. Montana: University of California Press, Publications in Geological Sciences, v. 134, p. $1-107$.

Carpenter, Kenneth, 1979, Vertebrate fauna of the Laramie Formation (Maastrichtian), Weld County, Colorado: University of Wyoming, Contributions to Geology, v. 17, no. 1, p. 37-49. 


\section{The MARShall LAMBert SyMPOSIUM ROAD LOG CONTRIBUTIONS}

Johnson, K.R., 1989, A high resolution megafloral biostratigraphy spanning the CretaceousTertiary boundary in the northern Great Plains [Ph.D. thesis]: New Haven, Yale University, $556 \mathrm{p}$.

Johnson, K.R., 1990, Megafloral changes across the Cretaceous-Tertiary boundary in the northern Great Plains and Rocky Mountains, U.S.A.: Geological Society of America, Special Paper 247, p. 433-444.

Johnson, K.R., 1992, Leaf fossil evidence for extensive floral extinction at the CretaceousTertiary boundary in North Dakota, U.S.A.: Cretaceous Research, no. 13, p. 91-117.

Nichols, D.J., and Fleming, R.F., 1990, Plant microfossil record of the terminal Cretaceous event in the western United States and Canada: Geological Society of America, Special Paper 247, p. 445-456. 


\section{The Marshall Lambert Symposium RoAd Log CONTRIBUtions}

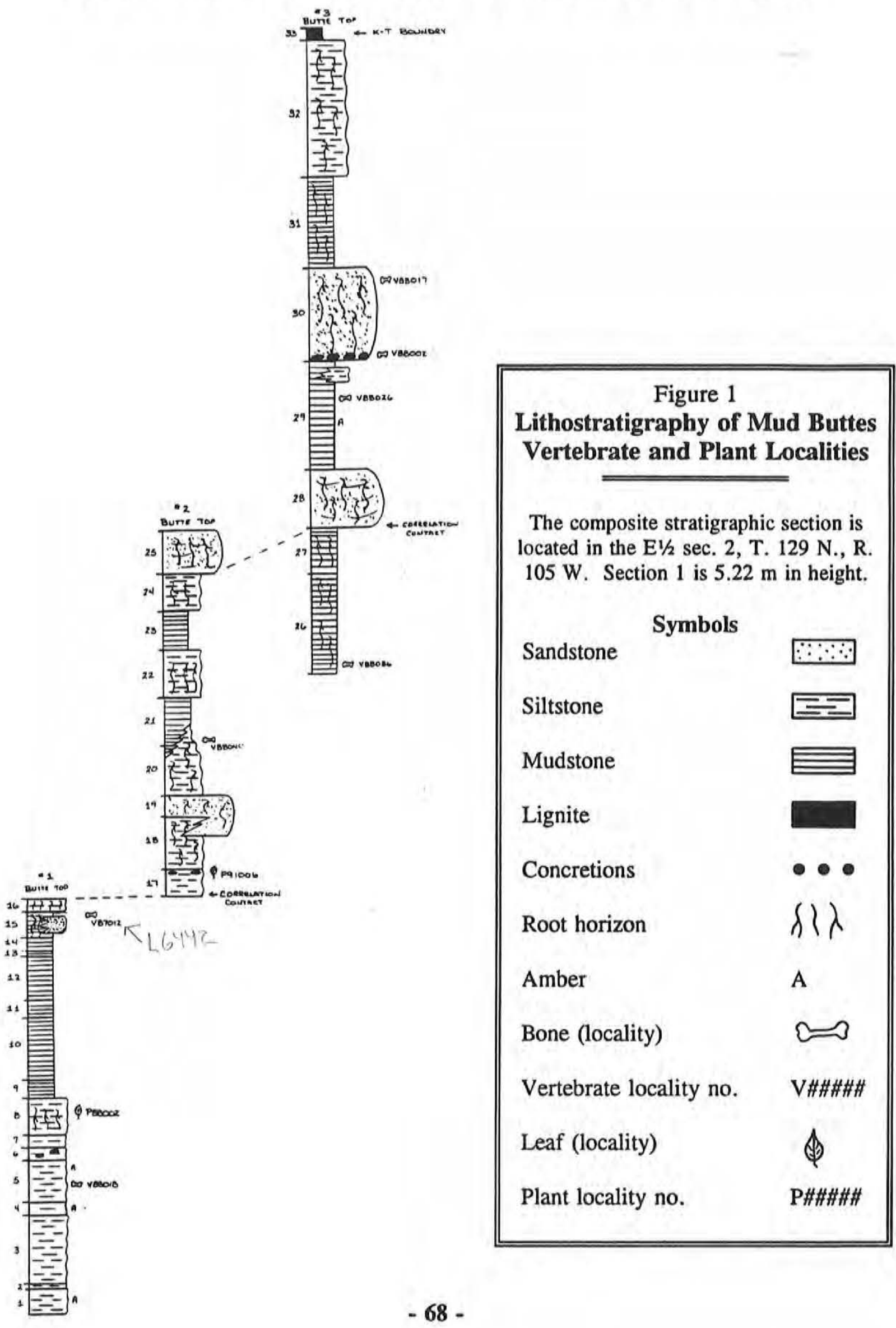




\title{
The Marshall Lambert Symposium RoAd LOG CONTRIBUTIONS
}

\section{THE UPPER CRETACEOUS OF SOUTHWESTERN NORTH DAKOTA- THE TRANSITION FROM MARINE TO TERRESTRIAL ENVIRONMENTS}

\author{
Allen J. Kihm \\ Department of Earth Science, Minot State University, Minot, ND 58701
}

Three Upper Cretaceous formations are exposed in southwestern North Dakota. These are, from oldest to youngest, the Pierre, Fox Hills, and Hell Creek Formations. This sequence of strata is essentially continuous and does not occur in outcrop elsewhere in North Dakota. These strata represent a transitional sequence from fully marine, through nearshore and shoreline, to fully terrestrial fluvial and paludal environments.

The Pierre Shale is a mostly black shale that is exposed or underlies portions of the Great Plains states from Kansas to North Dakota. These strata were deposited in a seaway that split the North American continent into an eastern (with Minnesota on the eastern shore) and a western landmass (dominated by the developing Rocky Mountains). The Pierre Shale has a maximum thickness of more than $915 \mathrm{~m}$ (3000 ft) (Gill and Cobban, 1966), but only about 41 m (135 ft) of it are exposed in North Dakota (Fisher, 1952). In Bowman County, the Pierre Shale contains a diverse molluscan fauna, consisting of 51 species, that indicate an age of upper Campanian to lower Maastrichtian (Brinster, 1970).

The Fox Hills Formation is mapped from Colorado north to the Canadian border. The Pierre-Fox Hills formational contact is gradational and is placed where the gray weathering claystones of the Pierre change to the light brown silty claystones and siltstones of the Trail City Member of the Fox Hills. This transition represents an influx of clastic sediment derived from the Rocky Mountains and marks a regional regression of the sea. The Fox Hills Formation consists of shoreline, estuarine, and offshore bar environments (Feldman, 1972) that are locally highly fossiliferous, with both body fossils and trace fossils (such as Ophiomorpha burrows). The formation is middle to upper Maastrichtian in age. The uppermost unit of the Fox Hills Formation is typically a sandstone (e.g., Colgate Sandstone Member), while the overlying Hell Creek Formation consists dominantly of claystones and siltstones. The contact between these formations is gradational and represents a shift from marginal marine to fully terrestrial environments. The contact between the Fox Hills and Hell Creek Formations is typically placed at the first significant carbonaceous bed.

\section{References}

Brinster, K.F., 1970, Molluscan paleontology of the Pierre Shale (Upper Cretaceous), Bowman County, North Dakota [M.S. thesis]: Grand Forks, University of North Dakota, 135 p.

Feldman, R.M., 1972, Stratigraphy and paleoecology of the Fox Hills Formation (Upper Cretaceous) of North Dakota: North Dakota Geological Survey, Bulletin 61, 65 p.

Fisher, S.P., 1952, The Geology of Emmons County, North Dakota: North Dakota Geological Survey, Bulletin 26, $47 \mathrm{p}$.

Gill, J.R., and Cobban, W.A., 1966, The Red Bird section of the Upper Cretaceous Pierre Shale in Wyoming: U.S. Geological Survey, Professional Paper 393-A, 91 p. 


\section{THE MARShall LAMBERT Symposium ROAD LOG CONTRIBUTIONS}

\section{MARMARTH}

\section{W.P.A. American Guide Project (1930s) \\ (reprinted with permission*)}

Marmarth is supposed to have evolved its name from the first syllables of the names of two little girls, Mary and Martha, the grand daughters of President Earling of the C. M. St. P. \& P. R. R. [Chicago, Milwaukee, St. Paul, \& Pacific Railroad].

According to a history sketch written for the Bowman County News in 1908 the first white man who lived on the site of what is now Marmarth was Walter Brewster, Sr. He had a dugout on the spot in 1882 which he used as his buffalo hunting headquarters. His son, Walter, Jr., was born on Ash Coulee and was ranching on Lone Creek in 1908. The daughter, Rose, of Brewster, Sr., became Mrs. Allen Armstrong.

Before the founding of the town range cattle grazed the little valley, for ranchers had settled in the vicinity some years before.

The first post office was started at the place in 1902 by Mrs. M.E. Mash. The first business establishment was the Harrison Hotel kept by Dick Harrison. At first it was only a tarpaper covered building situated on the grounds where the ball park is now. Mr. Harrison built a new hotel in 1908 with 40 rooms. By this time he had a competitor, the Woods Hotel with 50 rooms kept by M.F. Woods. The first store in Marmarth was in the building now used by Mable Mickelson for a dress shop. The First National Bank incorporated in 1908. By Oetober of the same year Marmarth already had a population of 600 which was steadily increasing. The reason for its rapid growth was the establishment at the town of a division of the Milwaukee Railroad. There was also a cement block factory in town where the Meinecke Cement Block company operated a plant night and day employing a large force of men. Many buildings in Marmarth and the surrounding towns were built with blocks manufactured here.

Marmarth is situated in the southwest corner of Slope county on the Little Missouri at a point where Hay Creek joins it from the cast and Beaver Creek from the west.

Highway U.S. 12 passes through the center of town. It is six miles from the Montana line. It is surrounded and protected on all sides by high river bluffs. Coming in sight of town from the highway or railroad one is impressed [at] seeing a desert oasis for he has just passed through several miles of barren Badlands and the town is in a beautiful fertile valley. Many trees line the streets and surround the dwellings.

During the years several floods have been suffered in Marmarth due to the overflowing of the river. The cause of these disasters has been remedied by changing the channel of the stream so that it now runs on the east side of town, by building a large dike and by damming Beaver Creek which has already been mentioned as flowing in at this point.

Marmarth has always been in a ranching community. Some of the earliest ranchers in the region were M.F. Woods (he was the first), Frank Ash and Doc Spry on Beaver Creek. Spry was already popular with the ranching fraternity. He still lives at Marmarth. In early days he and Ash found that they could raise excellent crops of alfalfa along the creek by using irrigation methods.

The fact that this town was in the center of a ranching country encouraged the railroad to build large stock-yards there in 1908. These yards now cover 45 aeres. They are equipped with electric lights, a water tank and a water distributing pipe throughout leading to concrete water troughs. There are 86 loading and sorting pens and 15 loading chutes. There is a house for the yard foreman. The first yard foreman was John Wyman. The largest number of carloads of stock shipped out in one year was in 1934. There was 922 carloads. These stock yards are on the site of the old OX ranch.

Marmarth's present population is 821 but it has diminished by the removal of the railroad workshops. Tourists can obtain fine camp accommodations at Lamb's Filling station or at either of the hotels, the St. Charles or the Yellowstone. The rates range from $\$ 1.00$ to $\$ 2.00$.

* See Road Log Contributors for citation and explanation. 


\title{
The Marshall LAMBert Symposium RoAd Log ContributionS
}

\section{FORT DILTS}

\author{
W.P.A. American Guide Project (1930s) \\ (reprinted with permission*)
}

In 1864 a train of eighty emigrant wagons was surrounded by Indians at a point $1 / 2$ mile north and $11 / 2$ miles west of the present location of Ives, N.D. [The site was] named for Jefferson Dilts, head scout of the expedition who was killed during the siege and buried there. The expedition was made up of emigrants on their way to the gold fields of Montana and Idaho. These people gathered at Fort Riddley, Minnesota, and set forth with 97 wagons in the train on July 14, 1864, under the leadership of Capt. Jas. L. Fiske. They were accompanied by soldiers for protection from Indians. After a pleasant journey they reached Fort Rice in Dakota Territory about 20 miles south of Bismarck, on the Missouri. There they left 8 army wagons carrying supplies and 7 wagons belonging to emigrants who suffered "cold feet." The westward journey finally brought them to a point on the west fork of Deep Creek some fifteen miles south and 15 miles west of Amidon. Here the wagon of Walter Fewer, which contained chiefly tobacco and liquor, was accidently overturned. A guard of nine men was left to help Fewer. No sooner had the caravan passed over a hill than a whooping band of Indians attacked Fewer and his assistants. Those ahead heard the shooting and hurried back only to find all dead but three, who died later of their wounds. Two wagons were lost in this attack. A man who had been disobedient to the rules of the expedition had been tied behind this last wagon with handeuffs on his wrists for punishment. He [had been] taken alive and burned at the stake. The following night was a wretched one for the travelers. It rained heavily and Indians were expected every moment. None came. In the morning they moved on in search of a better camp site. Incidentally they left some poisoned bread behind for the savages. About 25 of them died eating the bread. Approximately three miles farther on, at about $10 \mathrm{a} . \mathrm{m}$., Sept. 5, they come to the spot which is now Fort Dilts. The 80 remaining wagons were drawn up in a circle with the right front wheel of each wagon to the left hind wheel of the one in front. Ten to fifteen feet away from this ring of wagons a bank of earth was thrown up over 3 feet high and topped with 6 feet of sod. This defense was well up by 3 p.m. An entrance was left to the southeast. The tents of the soldiers were set in the space between wall and wagons. The tent of H.H. Larned was used as a hospital. There was sufficient space within the wagon circle for their 500 animals. Contradictory facts are extant regarding the means of obtaining water. According to W.M. Weinett, historian at Valley City State Teachers college, a spring was within the enclosure, but in the records given by H.H. Larned who was with the expedition, was then 19 years old and took a prominent part during the encampment, he states that the water was hauled in a wagon under guard one-third to one-half mile from south of the fort. The grazing was good. Under guard of 100 men divided into 25 squads of 4 men each the animals were taken out 100 at a time for two hours but later they were all taken three hours in the morning and 3 hours in the afternoon.

A short time after their arrival they were surprised to see some 300 Indians on a hill a mile away. Three riders left the others and approached to within half a mile carrying a white flag. They planted the flag in the ground and stood waiting near-by. Capt. Fiske dispatched three men to see what was wanted. To the flag was pinned a note written in the English language by a woman's hand. It was signed by Mrs. Fanny Kelly. She had been captured by the Indians nearly two months before. They wished to trade her for 40 head of cattle, some gun powder and iron for arrowheads. Mrs. Kelly included a personal plea for her rescue. Fiske felt that he dare not give the savages what they asked for but offered 3 horses and a load of food for the woman's ransom. This the Indians would not accept and Mrs. Kelly was taken away. However it was later learned that she was surrendered to the people at Fort Sully and was taken back to her home. In the dark of the second night Lt. Smith took 13 of the best riders and left for Fort Rice, some 200 miles away, to bring help. On the 16 th day after he left he returned with the soldiers to rescue the besieged gold-seekers. The whole expedition started back on Sept. 22, giving up their hopes of reaching the gold fields. At Fort Rice they broke up, many returning home by going down the river. Some of then went to Idaho with Capt. Fiske two years later.

Fort Dilts was dedicated to Jefferson Dilts August, 1932, by State Historical Society and eleven standard government grave markers were placed on the site. It is now called Fort Dilts Park. It contains 8.26 acres which was donated by L.G. Dawes of Rhame, N.D. The earthen breastwork thrown up by the embattled travelers is still distinguishable. The park is enclosed by a fence. To reach this point one must leave U.S. 12 turning north at the first school house on highway east of Marmarth. This school is known as the Ives school. After following the road north across the railroad one turns into a field and drives to the farm yard of John Chmura. The fort is located approximately 1 mile north of this place.

* See Road Log Contributors for citation and explanation. 


\section{THE MARShall LAMBert Symposium RoAd Log CONTRIBUTIONS}

\section{THE RHAME COMMUNITY}

\section{W.P.A. American Guide Project (1930s) \\ (reprinted with permission*)}

"Petrel" was the name given to a little place started in 1907 about one-half mile west of the present location of Rhame, North Dakota. When the Milwaukee R.R. came through, the little depot built some short distance east of Petrel was given the name of "Rhame" which was the name of an assistant engineer working on the road. The residents of Petrel moved to the new location.

The first building in Rhame was a temporary depot where R.W. Cornell, now of Scranton, North Dakota was the first station agent. At first Mr. Cornell had to walk nearly a mile for his meals. However, the company soon built him a house and Mrs. Comell joined him. For two months she was the only woman in Rhame.

As soon as the assurance of the coming of the railroad was ascertained plans for establishing places of business were made. Elliot \& Lamb were the pioneers in business at the place, building a grocery and hardware store and later adding a blacksmith shop. The Atlas Lumber company came second, in February, 1908, with B. H. Roberts as first manager. Next E.F. Canty opened a livery barn managed by Chas. Martin. In April O.E. Reilly established the Gem Restaurant. The first issue of the "Rhame Review" was dated April 23. H.N. Lynn was the editor. Messrs. Hawks and Henry started a livery barn and meat market. The Hotel Rhame began business May 1, Harry Gilfoy, proprietor. Two pool rooms started up, one by Brophy \& Gilfoy and one by L.E. McNew. John Abledinger conducted the first barber shop. The first bank was founded in the middle of June with Ole Paulson president; Theo. Torbenson, vice-president, and Simon Brown, cashier. By the middle of October, 1908, besides those already mentioned, there was a second general store by Ole and A. Svendby; Rhame Lumber company by E.M. Hanson and O.S. Jordet; a second hotel, "The Golden West," H.O. Olson, proprietor, (This little hotel burned down in 1913 and was replaced by the "Buttes Hotel" in the same year); and a drug store in which S.P. Kelly was druggist. Men who had much to do with the building of these institutions of business were contractors C.B. Ruble and P.J. Fisher, and C.R. DeFoe, a plasterer and bricklayer. The first physician was Dr. Lochead, who had a claim in Billings County ten miles from Rhame and spent 3 days of each week in town in his professional efficiency.

The first school was held in a rented claim shack a mile from town and taught by Miss Monroe. The members of the school board were J.H. Lamb, Jas. Hadley and F.E. Long, with H.N. Lynn clerk, and H.O. Baker, treasurer.

In 1909 there were about 25 persons in the town. Since this early beginning it has grown and prospered to supply the increasing needs of the farmer-rancher community in the midst of which it is situated. Rhame now boasts a population of 356 , according to the 1930 census.

* See Road Log Contributors for citation and explanation. 


\title{
The Marshall Lambert Symposium RoAd Log CONTRIBUtions
}

\section{TEDDY ROOSEVELT UP THE LITTLE MISSOURI RIVER}

\author{
Joseph H. Hartman \\ Energy \& Environmental Research Center, University of North Dakota, \\ Grand Forks, North Dakota 58202
}

Probably one of the more famous nonpaleontological visitors to traverse through the type area outcrops of the Bullion Creek Formation and the brackish tongues of the Cannonball Formation, and view the stratotype of the Slope Formation, was the future President of the United States of America, Theodore Roosevelt. In September of 1883, Roosevelt stepped off the railway platform at the collection of a few buildings known as Little Missouri. Medora, the better known town site to survive Little Missouri, was then only recently under construction by the Marquis de Morés.

Shortly after his arrival, with guide Joe Ferris, Roosevelt headed south to hunt buffalo. As is easily imagined, "nowhere was there any sign of human life, save for an almost invisible wagon trail zigzagging from side to side of the crazily meandering [Little Missouri] river...They had been traveling south steadily for almost an hour before Roosevelt saw the first settler's log house, near the mouth of Davis Creek..." known as the Custer Trail Ranch, "...named after the doomed colonel who had camped there in 1876" (Figure 1) (Morris, 1979, p. 211, 212). Their camp was located approximately in sec. 10, T. 139 N., R. 102 W. (Chimney Butte Quadrangle, 1979), not far from East River in western Billings County.

"Seen by Roosevelt in the gloom of early evening, it must indeed have seemed like a landscape of death. There were pillars of corpse-blue clay, carved by wind and water into threatening shapes; spectral groves where mist curled around the roots of naked trees; logs of what looked like red, rotting cedar, but which to the touch felt petrified, cold, and hard as marble; drifts of sterile sand, littered with buffalo skulls; bogs which could swallow up the unwary traveler-and his wagon; caves full of Stygian shadow; and, weirdest of all, exposed veins of lignite glowing with the heat of underground fires, lit thousands of years ago by stray bolts of lightning. The smoke seeping out of these veins hung wraithlike in the air, adding a final touch of ghostliness to the scene. Roosevelt could understand why the superstitious Sioux called such territory Mako Shika, 'land bad..." (Morris, 1979, p. 212).

Roosevelt's first night was spent at the Maltese Cross Ranch (later to be Roosevelt's brand), sacked out on the ground in the "small log hut in a mile-wide valley" (Morris, 1979, p. 213). Traveling from Medora, Roosevelt witnessed the numerous petrified stumps common to the Bullion Creek Formation, which is well exposed on the steep river bluffs (see Fastovsky and McSweeney, 1991). The results of spontaneous lignite burns are in evidence everywhere in the valley drainage. The caprock of many ridges is the clinker produced by the burn of the H T Butte lignite, representing the contact between the Bullion Creek and Sentinel Butte Formations. The smoldering of burning lignite can be observed at sites such as "Burning Coal Vein" park along the north edge of Slope County (accessed from U.S. 85). The "caves," usually 


\section{The Marshall Lambert Symposium RoAd LOG CONTRIBUTIONS}

representing tunnels produced by rivulets in semiconsolidated sediments, often occur along lines of weakness produced by slumping bluff faces. The Maltese Cross Ranch was located in about sec. 21, T. 139 N., R. 102 W. (Chimney Butte Quadrangle) in a relatively straight reach almost a mile wide.

"In the clear light of early morning [Roosevelt] could see that the Bad Lands were neither hellish nor threatening, but simply and memorably beautiful. The little ranch house, alone in its bottomland, commanded a magnificent view of westward rolling buttes. There sandstone caps broke level; flat bits of flotsam on a tossing sea of clay. The nearer buttes, facing the river, were slashed with layers of blue, yellow, and white. In the middle distance these tints blended into lavender, then the hills rippled paler and more transparent until they dissolved along the horizon, like overlapping lines of watercolor. Random splashes of bright red showed where burning coal seams had baked adjoining layers of clay into porcelainsmooth 'scoria.' Thick black ribs of lignite stuck out of the riverside cliffs...Their proximity to the Little Missouri River told the whole geological story of the Bad Lands. Here two of the four medieval elements-fire and water-had met in titanic conflict. So chaotic was the disorder, wherever Roosevelt looked, that the earth's crust appeared to have cracked under the pressure of volcanic heat. Millions of years of rain had carved the cracks into creeks, the creeks into streams, streams into branchlets, the branchlets into veinlets. Each watercourse multiplied... until it seemed impossible for the pattern to grow more crazy" (Morris, p. 213-214).

Although poetically contrived, representing rocks of nonvolcanic origin, and a chronology of uncertain duration, Roosevelt was in the badlands to escape the rush of New York politics, to test his mettle and absorb, almost mystically, the frontier. As Roosevelt and Ferris forded and reforded the Little Missouri River, late that day they reached their destination, the Lang Ranch at the mouth of Cannonball Creek, which was then known as Little Cannonball Creek (Putnam, 1958). Cannonball Creek empties into the Little Missouri River in sec. 29, T. 135 N., R. $106 \mathrm{~W}$. (Pretty Butte Quadrangle, 1980). The Lang Ranch would become the cattle ranch known as the 777 (at the mouth of Horse Creek) (Slope Saga Committee, 1976) and, later, the Brown Ranch, the hospitable hosts of many a wandering geologist and paleontologist. The strata exposed along Cannonball Creek includes the Cannonball lignite (of Hares, 1928), which represents the formational contact between the Hell Creek and overlying Ludlow Formations (see Hartman, 1993, this volume). The Cretaceous-Tertiary boundary is at an horizon near the base of the lignite.

Roosevelt's search for his elusive buffalo resulted in his experiencing all of the better elements faced by geologists in this well-traveled section of the Little Missouri River.

"He slept enough, at any rate, to be up at dawn. The sound of rain drumming fiercely on the cabin's roof did not deter him from beginning his buffalo hunt immediately. Joe Ferris protested they should wait until the weather cleared, and the Langs warned that he would find the clay slopes round about too greasy to 


\section{The Marshall Lambert Symposium RoAd Log CONTRIBUtions}

climb. But 'he had come after buffalo, and buffalo he was going to get, in spite of hell or high water.' At six o'clock Roosevelt and Ferris mounted their horses and rode east into a wilderness of naked, streaming hills. All day the rain continued. The clay slopes, slimy to begin with, dissolved into sticky gumbo, and finally into quagmires that sucked at the horses' hooves, and squirted jets of black mud over the ridges... [Roosevelt] continued to grin through four more days of ceaseless rain. Joe Ferris protested every morning, and was on the point of caving in every evening, but Roosevelt seemed incapable of fatigue or despair" (Morris, 1979, p. 216, 217).

One thing seems clear, Roosevelt, with his naturalist leanings and determination, would have made a fine field paleontologist. Roosevelt eventually shot his buffalo and, in doing so, wandered about the type area of the Slope Formation exposed in T. 135 N., R. 105 W., Slope County (see Hartman, 1993, this volume). It seems too bad that Roosevelt had to ride into Montana to get his trophy.

\section{Notes and Acknowledgments}

Edmund Morris (1979) is quoted by permission of the Putnam Publishing Group. Mr. Morris provides an excellent visualization of the badlands of the Little Missouri River and how Roosevelt might have felt on his journey through what was considered by Roosevelt country to stir the blood. As always, I very much appreciate the thorough copy editing of Jane Russell (Energy \& Environmental Research Center). All map references are to U.S. Geological Survey 7.5-minute topographic maps.

\section{Figure Explanation}

Figure 1 Explanation. This map of the drainage of the Little Missouri River south of Medora includes information of both an historic and modern nature. The placement of ranches, Little Missouri, and route of the Northern Pacific Railroad (NPRR) is circa 1883 and is derived from Putnam (1958) and Hartman (1984). Other abbreviations include Theodore Roosevelt National Park (TRNP). Letters A and B in T. 135 N., R. 105 W. represent the stratotypes of the Slope Formation (A), and Three V (A) and Boyce (B) Tongues of the Cannonball Formation (see Hartman, 1993, this volume).

\section{References}

Fastovsky, D.E., and McSweeney, Kevin, 1991, Paleocene paleosols of the petrified forests of Theodore Roosevelt National Park, North Dakota: A natural experiment in compound pedogenesis: Palaios, v. 6, p. 67-80.

Hares, C.J., 1928, Geology and lignite resources of the Marmarth field, southwestern North Dakota: U.S. Geological Survey, Bulletin 775, 110 p.

Hartman, J.H., 1984, Systematics, biostratigraphy, and biogeography of latest Cretaceous and early Tertiary Viviparidae (Mollusca, Gastropoda) of southern Saskatchewan, western North Dakota, eastern Montana, and northern Wyoming [Ph.D. Thesis]: Minneapolis, University of Minnesota, 928 p., 19 pls. 


\section{The Marshall Lambert Symposium RoAd Log CONTRibutions}

Hartman, J.H., 1993, The type areas of the Paleocene Slope Formation and intercalated tongues of the Cannonball Formation, Slope County, North Dakota: North Dakota Geological Society, The Marshall E. Lambert Symposium Contributions and Road Log, Pioneer Trails Museum, June 19-20, 1993, Bowman, North Dakota.

Morris, Edmund, 1979, The Rise of Theodore Roosevelt: New York, Ballantine Books, 886 p.

Putnam, Carleton, 1958, Theodore Roosevelt: Volume 1, The Formative Years: New York, Charles Scribner's Sons, 626 p.

Slope Saga Committee, 1976, Slope Saga: Slope County, Slope Saga Committee, 1178 p. 
Figure 1

Map of the Little Missouri River Badlands South of Medora

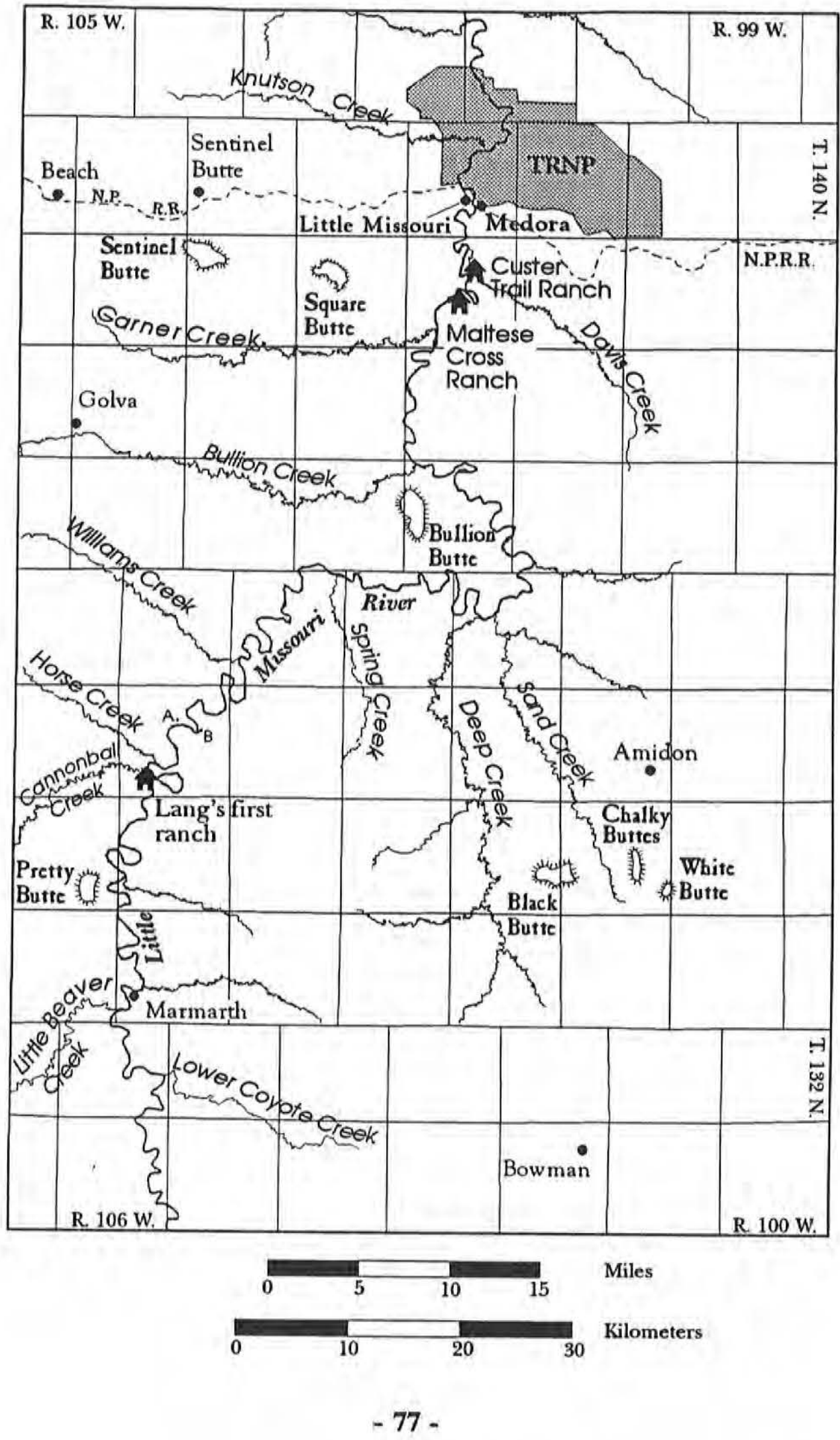




\title{
Road Log to \\ THE TYPE AREAS OF THE PALEOCENE SLOPE FORMATION AND INTERCALATED TONGUES OF THE CANNONBALL FORMATION, SLOPE COUNTY, NORTH DAKOTA
}

\author{
Joseph H. Hartman \\ Energy \& Environmental Research Center, University of North Dakota, \\ Grand Forks, North Dakota 58202
}

\section{Introduction}

The Slope Formation was named by Clayton and others (1977) for strata previously included in the upper part of the Ludlow Formation and lowermost portion of the Tongue River Formation (although usage has been inconsistent). Two marginal marine tongues of the Cannonball Formation intercalate with the Ludlow (restricted usage) and Slope formational sequence. In redefining the upper contact of the Slope Formation, Clayton and others (1977) also introduced the Bullion Creek Formation for strata between the Slope and Sentinel Butte Formations previously reported as the Tongue River Formation. The purpose of this road log is to guide the interested geologist and paleontologist to the type area of the Slope and tongues of the Cannonball Formations. The value or validity of the use of the Slope Formation, as a replacement for the upper portion of the Ludlow Formation, will be discussed in a contribution by Hartman and Cvancara (in prep.). That work will provide justification for the introduction of new names for the tongues of the Cannonball Formation. The lithostratigraphic nomenclature employed here follows that of the North Dakota Geological Survey (but see also Carlson, 1983). In contrast, the U.S. Geological Survey recognizes the Ludlow and Tongue River Members of the Fort Union Formation for the same stratigraphic sequence.

To those visiting the area described in this report, please contact appropriate landowners for permission to access property. In addition, please limit the collection of macrofossils (specifically brackish-water shell pods) of the tongues of the Cannonball Formation. These occurrences are very limited, particularly in the Boyce Tongue, and are needed for in situ field examination. The trail portion of the route will be considered by most travelers to be accessible in a pickup. All maps referred to are U.S. Geological Survey 7.5-minute series topographic quadrangles at a scale of $1: 24,000$. The writer wishes to acknowledge the cooperation and hospitality of the families of Clyde and John Brown, the patience of Ms. Carol Edwards of the U.S. Geological Survey Field Records Library, and the support of the National Science Foundation, U.S. Department of Energy, and U.S. Bureau of Mines in this research. I also wish to thank Dr. David W. Krause (State University of New York at Stony Brook) for his thoughtful comments on this and other contributions by the writer.

\section{General Access}

To access the type area of the Slope Formation from Beach, travel south to Golva on ND 16 and continue south about $11 \mathrm{~km}(7 \mathrm{mi})$ to a T-intersection. Travel west for $1.7 \mathrm{~km}(1 \mathrm{mi})$ and follow the curve in the road to the south. Continue south for $11 \mathrm{~km}(7 \mathrm{mi})$ to the Golden 


\section{The Marshall Lambert Symposium RoAd Log Contributions}

Valley-Billings County line. Access from Marmarth to the same county line intersection should be considered only under dry road conditions. On a wet day, numerous soft spots and a few creek fordings can cast a shadow on an otherwise pleasant undertaking. From U.S. 12, go north on the first road west of the Little Missouri River (about $1.6 \mathrm{~km}, 1 \mathrm{mi}$ ), for about $28.8 \mathrm{~km}$ (18 $\mathrm{mi})$, to the Slope-Golden Valley county line. There are essentially no possible turnoffs. The route takes the traveler past Pretty Butte, which is truly stunning in certain lighting situations, about $11 \mathrm{~km}(7 \mathrm{mi})$ north of U.S. 12. Pretty Butte, and much of the surrounding strata, is of the uppermost Cretaceous Hell Creek Formation. Pretty Butte is capped by a thick clinker, representing the baking of strata from the burn of an underlying coal bed. The route includes crossing the contact between the drab-colored Hell Creek and lighter-colored Ludlow Formations. This contact is frequently marked by a lignite and is closely correlated with the Cretaceous-Tertiary boundary.

\section{To the Type Slope Formation}

The intersection on the Slope-Golden Valley County line is located in the northwest corner of sec. 4, T. 135 N., R. 106 W., on the Ollie, Mont.-N. Dak. Quadrangle (1981), in the headwaters area of Horse Creek (Hartman, this volume, Figure 1). Travel east (following a number of south-directed curves) for about $7.5 \mathrm{~km}(4.7 \mathrm{mi})$ to a section line fence and cattle guard indicating the entrance to the Brown Ranch. The juncture of the road to Brown Ranch (to the southeast) and the trail to the stratotype of the Slope Formation occurs just east of the cattle guard in the northwest corner of sec. 7, T. 135 N., R. 105 W., on the Williams Lake Quadrangle (1979), Slope County, North Dakota. Follow the trail east on a steep, rutted road, for about $2.1 \mathrm{~km}(1.3 \mathrm{mi})$, across a valley of a tributary of Deer Creek. On reaching the trail juncture on an upland bench in the NW $1 / 4 \mathrm{NW}^{1 / 4}$ of sec. 8, take the southeast trail for about 2.2 $\mathrm{km}(1.4 \mathrm{mi})$ to the edge of Three V Crossing Quadrangle (1979) in the E $1 / 2 \mathrm{SE}^{1 / 4} \mathrm{NE}^{1 / 4} \mathrm{SW}^{1 / 4}$ sec. 9. The highly dissected badlands to the south are formed primarily in the Slope Formation, with flat-bottomed tributaries exposing the uppermost part of the Ludlow Formation. The drainage was informally referred to as School Section Creek by Moore (1976). Numerous surface-measured sections, one subsurface geophysical and mud-sampled section, and other geologic observations, dating back to the studies of Leonard (1908), have been made in this area. Follow the somewhat twisting road around an embayment of School Section Creek. The stratotype of the upper part of the Slope Formation can be viewed to the east at a few highground vantages along this route. Good views can be obtained of the type Slope from a platform overlooking the breaks south of the section line gate (to private land) separating sections 9 and 10. A bearing of $126^{\circ}$ transects the top of the slightly dome-shaped butte forming the top of the stratotype. In this view, the upper Slope Formation is exposed on dissected south-facing bluffs (Figures 1 and 2). The north side of the butte is a broad, grass-covered slope. Lenses of brackish-water fossils occur in the lower portion of the bluff, forming the upper portion of the type Slope section, and can be traced intermittently to this vantage.

The trail from the section line gate (secs. 9-10) trends southeast for about $0.6 \mathrm{~km}(0.4$ $\mathrm{mi}$ ), at which point the traveler has reached the stratotypes of the Slope Formation and the Three $\mathrm{V}$ Tongue of the Cannonball Formation. The type area was originally reported by Clayton and others $(1977$, p. 7) as "in the south-facing exposure in the northwest corner of section 15 and the southwest corner of section 10, T105N, R135W." The cited township and range is in error, 


\section{The MARShall Lambert Symposium RoAd Log Contributions}

representing a transposition of the numbers. The lower portion of the stratotype of the Slope Formation is located in south-facing exposures, which also bear the Boyce Tongue, in the $\mathrm{N}^{1 / 2}$ NW $1 / 4$ sec. 15, T. 135 N., R. 105 W., while the upper portion of the Slope Formation and the stratotype of the Three V Tongue of the Cannonball Formation are on southwest-facing exposures in the $\mathrm{S}^{1 / 2} \mathrm{SW}^{1 / 4} \mathrm{SW}^{1 / 4}$ sec. 10, T. $135 \mathrm{~N}$., R. $105 \mathrm{~W}$. (Figure 1; Hartman, this volume, Figure 1, Location A).

\section{The Slope Formation and Three V Tongue Stratotypes}

The Slope Formation is not fully represented in its type section (Figures 2 and 3). The nearest outcrop of the "white bed"-silcrete horizon used to demarcate the contact between the Slope Formation from the overlying Bullion Creek Formation is located about $8.8 \mathrm{~km}(5.5 \mathrm{mi})$ to the northeast and outside the scope of the present report. At the stratotype, the Slope Formation is about $68.7 \mathrm{~m}$ (225 ft) thick. Clayton and others (1977) reported a total thickness

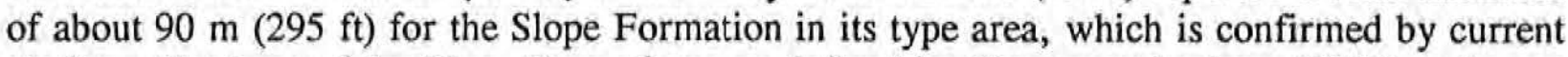
studies. The base of the Slope Formation was defined by Clayton and others (1977) at the top of a coal and carbonaceous claystone sequence identified as the T Cross bed. As they did not nomenclaturally distinguish or treat as significant the occurrence of the brackish-water beds in this section, the base of the Slope Formation consisted, where locally observed, of sediments deposited in environments related to the Cannonball Sea, here corresponding to the " $\mathrm{T}$ Cross clay" (Figures 3 and 5). As presented by Moore (1976), in reference to his upper Ludlow Formation, and discussed by Carlson (1983), the T Cross lignite (of Moore) represented the basal unit of the Slope Formation. Correlation of the thick T Cross lignite, in its reference area in the SW $1 / 4$ sec. 20, T. 133 N., R. 105 W., Marmarth SE Quadrangle (1979), in southern Slope County, into the type area of the Slope Formation (in T. 135 N., R. 105 W.) is uncertain and was not documented by previous studies (see Hartman, 1989). With the inclusion of the T Cross lignite (of Moore) in the basal Slope Formation, the lower tongue, referred to here as the Boyce Tongue, of the Cannonball Formation is intercalated within the lowermost part of the Slope Formation. As defined by Clayton and others (1977), the Boyce Tongue represents a lithostratigraphic unit between the Ludlow and overlying Slope Formation (Figure 5).

The brackish-water sediments occurring above the Boyce Tongue are herein referred to as the Three V Tongue of the Cannonball Formation (Figures 2 and 3; Hartman and Cvancara, in prep.). Fossils from this horizon were probably first recognized by A.G. Leonard in 1907 (Leonard, 1908). The bed containing these fossils has been called the upper or $\mathrm{U}$ tongue (e.g., Van Alstine, 1974) and Oyster tongue (e.g., Brown, 1948; Belt and others, 1984). The Three V Tongue is largely coincident with the "Oyster clay" unit reported by Moore (1976) and is noted for its lenses of brackish-water macrofossils that occur in the south-facing exposures along the north rim of the School Section Creek (of Moore) drainage. The lenses are composed of bivalve taxa from the families Ostreidae, Corbiculidae, and Corbulidae (Van Alstine, 1974; Hartman and Cvancara, in prep.). The palynomorph studies of Timothy J. Kroeger, as part of his dissertation studies at the University of North Dakota, will provide additional interpretation on the environments of deposition represented by the Slope Formation in its type area. 


\section{The Marshall Lambert Symposium RoAd Log Contributions}

\section{To the Boyce Tongue}

The journey to the type area of the Boyce Tongue of the Cannonball Formation requires the traveler to navigate a difficult (impassable to most) hairpin turn, which has been largely reclaimed by a back-cutting rivulet. Navigating the trail on foot from this point is prudent. Follow the trail south for about $0.1 \mathrm{~km}(0.8 \mathrm{mi})$ and then due east for about $0.8 \mathrm{~km}(0.5 \mathrm{mi})$ to where the trail turns to the northeast. At this juncture, a wide, flat river plain can be seen to the southeast, bounded by an exaggerated meander loop of the Little Missouri River. On a bearing of about $140^{\circ}$, descend the nose of the promontory to and across the flats for about 3 $\mathrm{km}(1.86 \mathrm{mi})$. This route parallels the south flank of the meander loop and brings the traveller to the bluffs that include the type area of the Boyce Tongue of the Cannonball Formation (Figure 4; Hartman, this volume, Figure 1, Location B). A wade across the Little Missouri River will be necessary for closer examination.

\section{The Boyce Tongue Stratotype}

The occurrence of brackish-water fossils at a horizon immediately above the $\mathrm{T}$ Cross lignite (of Moore) (Figure 4) was probably first noted by C.J. Hares in 1911 (Hares, 1911, Section 137). This report, however, went unreported, but was noted by Roland Brown, who rediscovered the occurrence in 1931 (Brown, 1948, 1962). His observations, and those to follow, were taken in the NE $1 / 4 \mathrm{NW}^{1 / 4} \mathrm{SW}^{1 / 4}$ of sec. $14, \mathrm{~T} .135 \mathrm{~N}$., R. $105 \mathrm{~W}$., on the Three V Crossing Quadrangle. Brackish-water fossils at this level have been referred to as the lower or L tongue (e.g., Van Alstine, 1974), Corbula tongue (Brown, 1948), and Corbicula tongue (e.g., Belt and others, 1984), and is largely coincident with the "T Cross clay" of Moore (1976). The same molluscan families reported for the Three V Tongue are also present in the Boyce Tongue (Van Alstine, 1974; Hartman and Cvancara, in prep.).

\section{Figure Explanations}

Figure 1. Type Area of the Slope Formation. A northeast view of the type area of the Slope Formation in sections 10 and 15, T. 135 N., R. 105 W. (Hartman, 1991; Hartman, 1993, this volume, Figure 1, Location A). The photo is from a bluff on the west side of the Little Missouri River in the SW $1 / 4$ of sec. 16. Section M1721 is one of a number of sections measured in this area (M-numbers represent geological observations maintained in a catalog by the Energy \& Environmental Research Center). The Boyce and Three V Tongues of the Cannonball Formation occur in the lower and upper bluff faces, respectively. The Boyce Tongue overlies the "T Cross lignite of Moore" (see also Figure 4) and the Three V Tongue occurs in the lower portion of exposures in the upper bluff (see Figure 2). The trail described in the text can be (barely) observed on the left edge of the photograph (on the west end of the exposures) and just below the exposures of the upper bluff.

Figure 2. Type area of the Three V Tongue. An easterly view of the upper portion of the Slope Formation exposed in its type area, including the stratotype of the Three V Tongue of the Cannonball Formation (Hartman, 1991). Note the presence of the trail (in foreground) described in the text. 


\section{The Marshall LAMbert SYMPOSIUM ROAD LOG CONTRIBUTIONS}

Figure 3. Stratotype of the Slope Formation. This geologic section is derived from the combined interpretation of Moore (1976), Belt and others (1984), T.J. Kroeger (University of North Dakota, unpublished observations, 1988), and Hartman (unpublished observations, 1990). In this section, the Boyce and Three V Tongues would have been identified by Moore (1976) as the $\mathrm{T}$ Cross clay and Oyster clay, respectively. The placement of the Ludlow-Slope formational contact is after Clayton and others (1977) (see Carlson, 1983; and text for discussion).

Figure 4. Type area of the Boyce Tongue. An easterly view primarily of the lower portion of the Slope Formation in its type area, including the stratotype of the Boyce Tongue of the Cannonball Formation immediately overlying the T Cross lignite (of Moore).

Figure 5. Chronostratigraphy of North Dakota Paleocene strata. This drawing illustrates the relative occurrence of the Boyce and Three V Tongues of the Cannonball Formation as interpreted from far-western North Dakota in the valley of the Little Missouri River.

\section{References}

Belt, E.S., Flores, R.M., Warwick, P.D., Conway, K.M., Johnson, K.R., and Waskowitz, R.S., 1984, Relationship of fluviodeltaic facies to coal deposition in the lower Fort Union Formation (Paleocene), south-western North Dakota, in Collinson, J.D., and Lewin, J., eds., Modern and ancient fluvial systems: International Association of Sedimentologists, Special Publication 6, p. 177-195.

Brown, R.W., 1948, Correlation of Sentinel Butte shale in western North Dakota: American Association of Petroleum Geologists, Bulletin, v. 32, p. 1265-1274.

Brown, R.W., 1962, Paleocene flora of the Rocky Mountains and Great Plains: U.S. Geological Survey, Professional Paper 375, 119 p.

Carlson, C.G., 1983, Geology of Billings, Golden Valley, and Slope Counties, North Dakota: North Dakota Geological Survey, Bulletin 76, pt. 1, 40 p.

Clayton, Lee, Carlson, C.G., Moore, W.L., Groenewold, G.H., Holland, F.D., Jr., Moran, S.R., 1977, The Slope (Paleocene) and Bullion Creek (Paleocene) Formations of North Dakota: North Dakota Geological Survey, Report of Investigations, no. 59, 14 p.

Hares, C.J., 1911, unpublished field notes, U.S. Geological Survey, Field Records Library, acc. no. 3299 b.

Hartman, J.H., 1989, The T Cross Coal Bed (Paleocene, North Dakota): The importance of reevaluating historic data in geologic research: North Dakota Academy of Science, Proceedings, 81st Annual Meeting, v. 43, p. 49.

Hartman, J.H., 1991, Coal science: Earth resource evaluation and management: Energy \& Environmental Research Center, 1991 Annual Report, July 1, 1990, through June 30, 1991, p. 240-242.

Hartman, J.H., 1993, Teddy Roosevelt up the Little Missouri River: North Dakota Geological Society, The Marshall E. Lambert Symposium Contributions and Road Log, Pioneer Trails Museum, June 19-20, 1993, Bowman, North Dakota (this volume).

Hartman, J.H., and Cvancara, A.M., in preparation, Paleocene stratigraphy and molluscan paleontology of the Cannonball (brackish) and Ludlow and Slope (nonmarine) Formations in southwestern North Dakota. 


\section{The Marshall Lambert Symposium RoAd Log Contributions}

Leonard, A.G., 1908, The geology of southwestern North Dakota, with special reference to coal: North Dakota Geological Survey, Fifth Biennial Report, p. 27-114.

Moore, W.L., 1976, The stratigraphy and environments of deposition of the Cretaceous Hell Creek Formation (reconnaissance) and the Paleocene Ludlow Formation (detailed), southwestern North Dakota: North Dakota Geological Survey, Report of Investigation 56, $40 \mathrm{p}$.

Van Alstine, J.B., 1974, Paleontology of brackish-water faunas in two tongues of the Cannonball Formation (Paleocene, Danian), Slope and Golden Valley Counties, southwestern North Dakota [M.S. Thesis]: Grand Forks, University of North Dakota, 101 p. 
The MARShall LAMBERT Symposium ROAD LOG CONTRIBUTIONS

Figure 1

Type Area of the Slope Formation

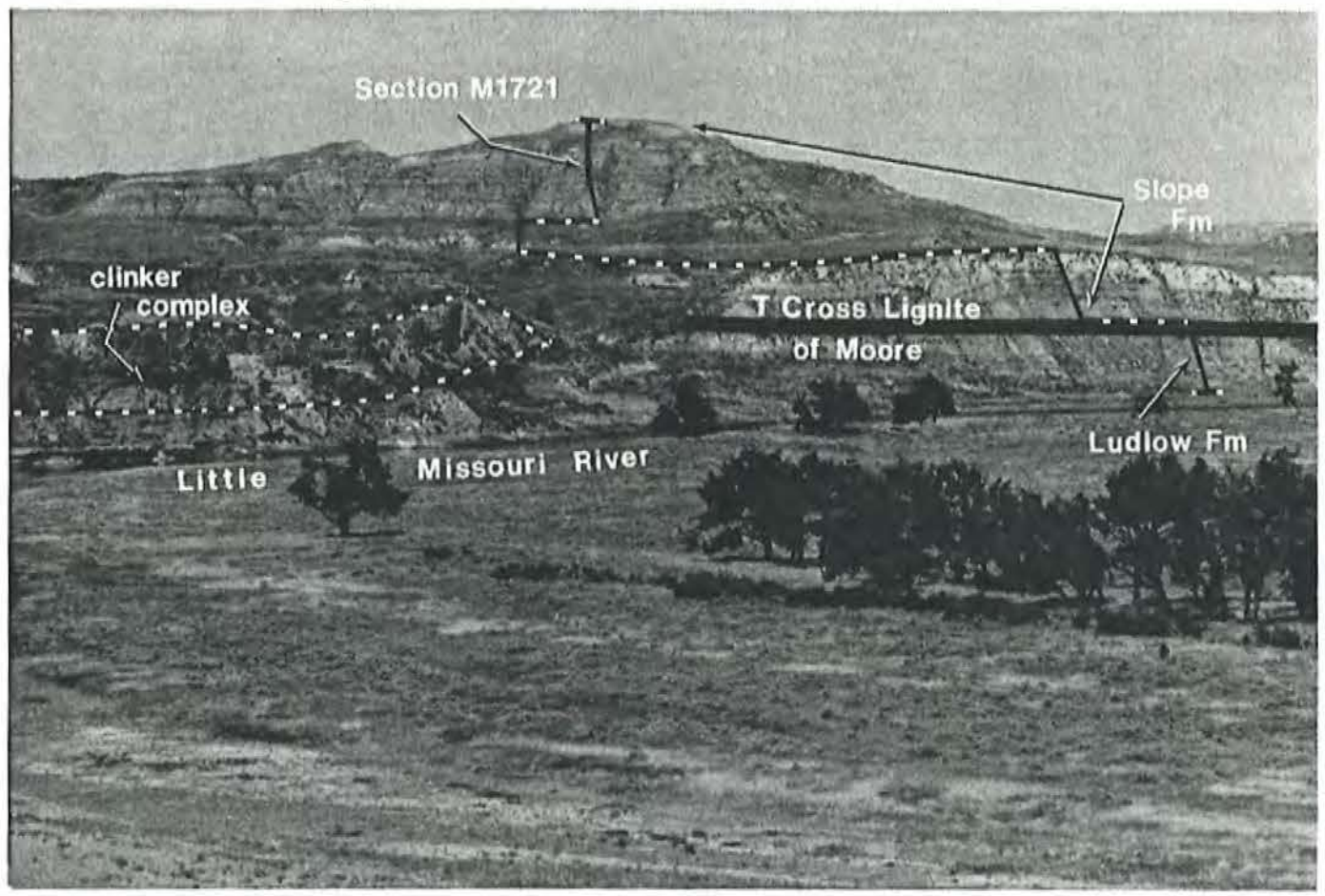

Figure 2

Type Area of the Three V Tongue

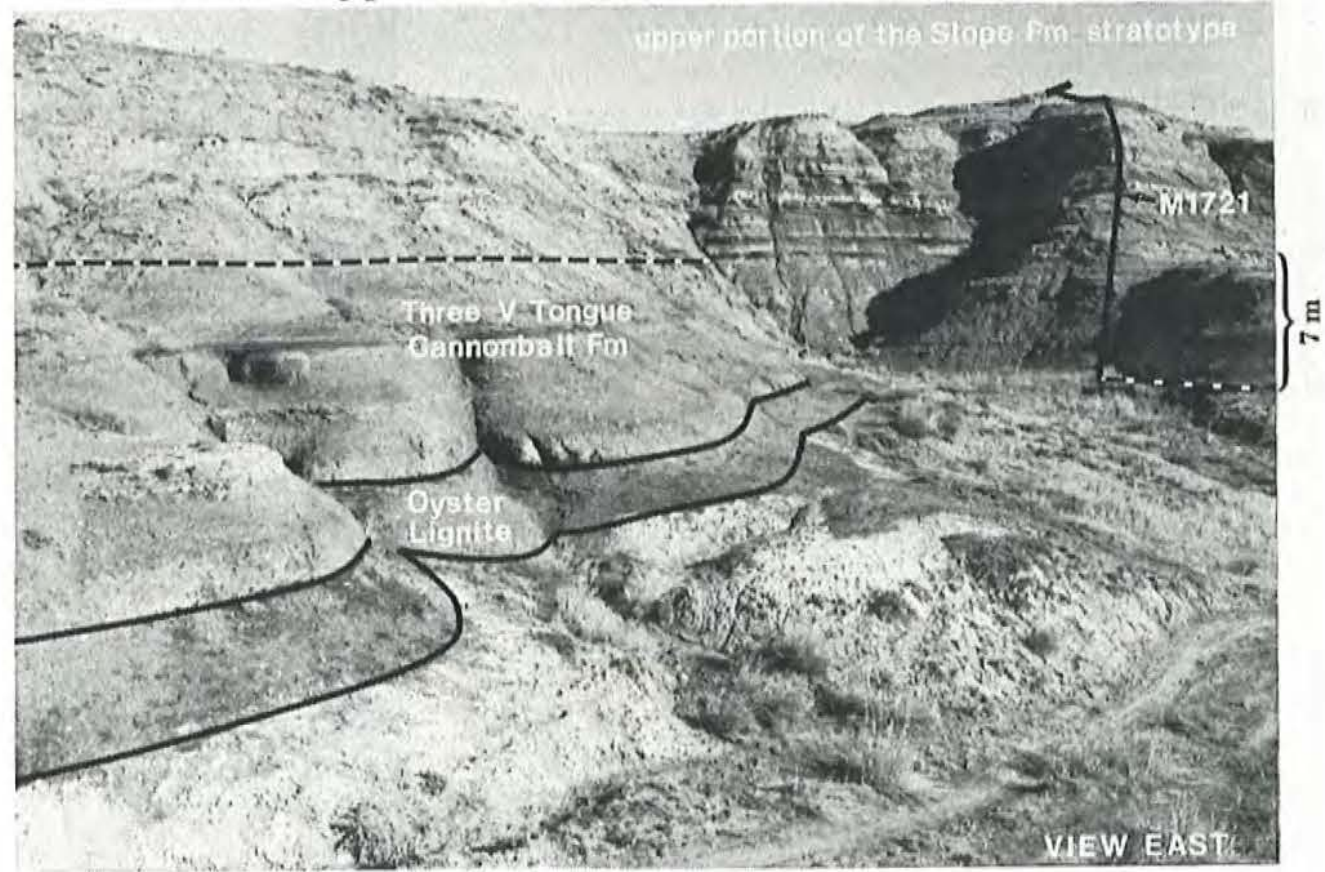


Figure 3

\section{StRATOTYPE OF THE SLOPE FORMATION}
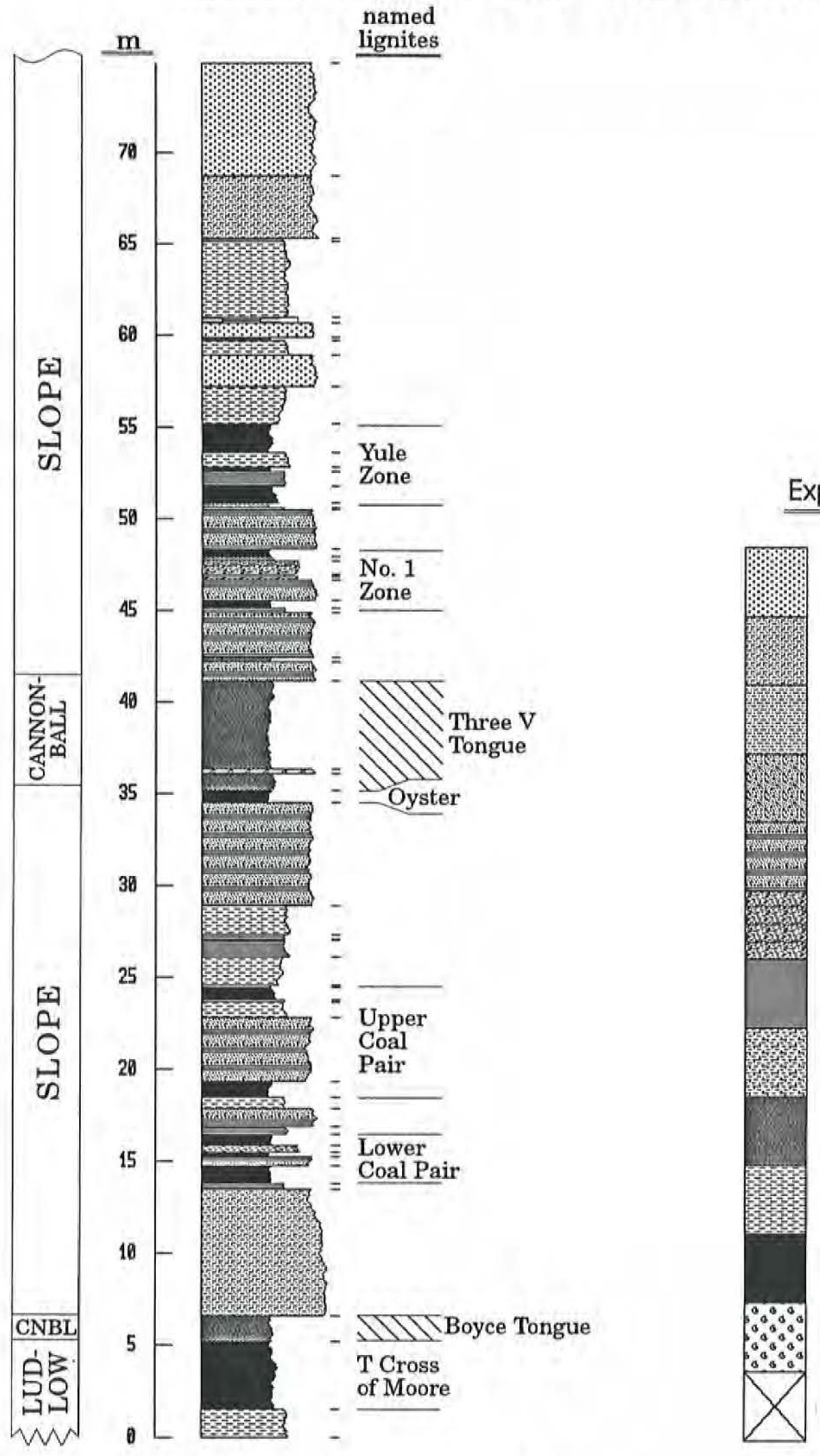

Fine-grained sandstone

Clayey sandstone

Mudstone

Siltstone

Alternating claystone, shale, and sandstone

Lignitic clastic rock

Lignitic shale

Calcareous shaleclaystone

Carbonaceous shale-claystone

Claystone

Lignite

Fossiliferous bed or lens

Covered interval 
The Marshall Lambert Symposium RoAd Log Contributions

Figure 4

Stratotype of the Boyce Tongue

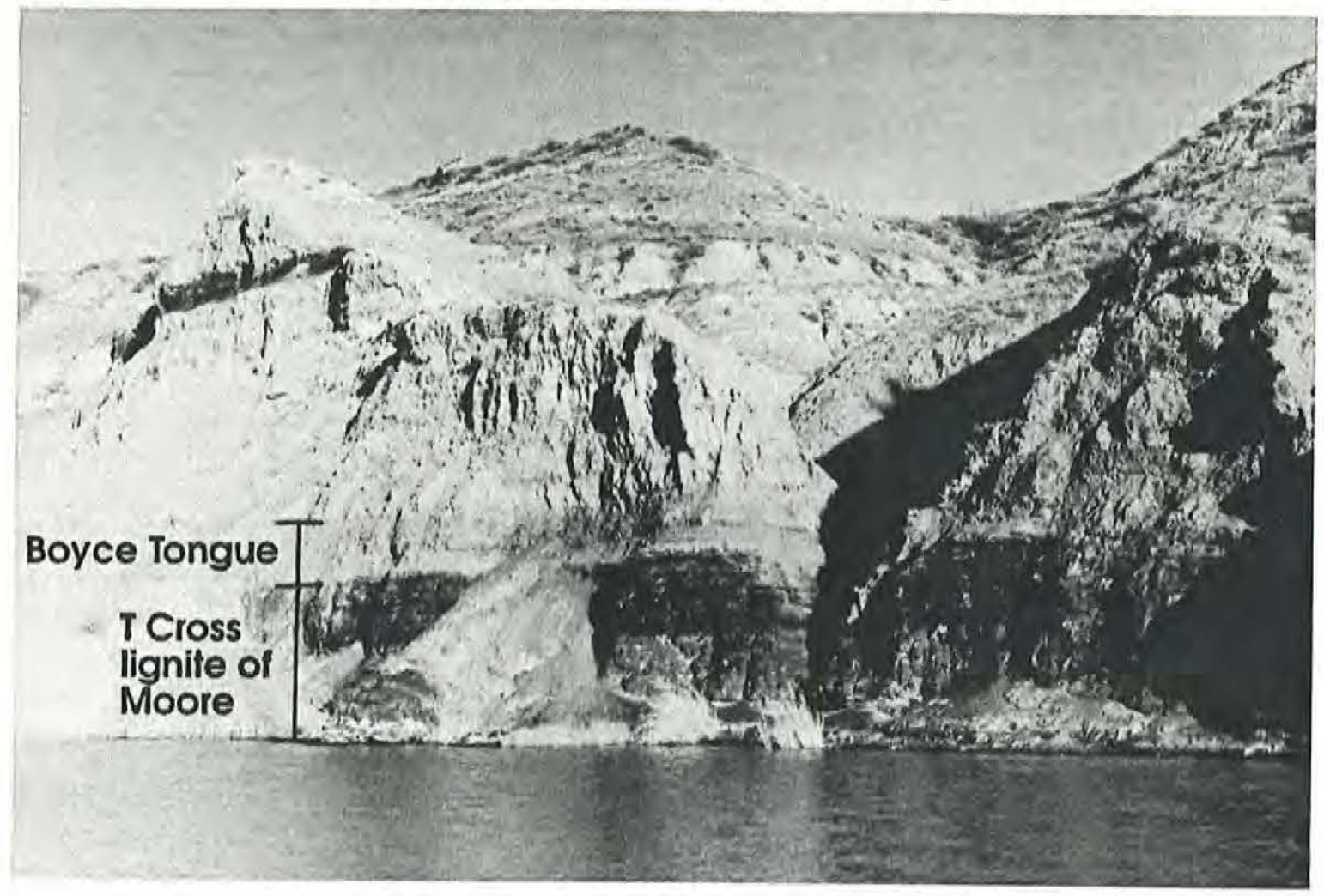

Figure 5

Chronostratigraphy of North Dakota Paleocene Strata MT-ND (WESD)

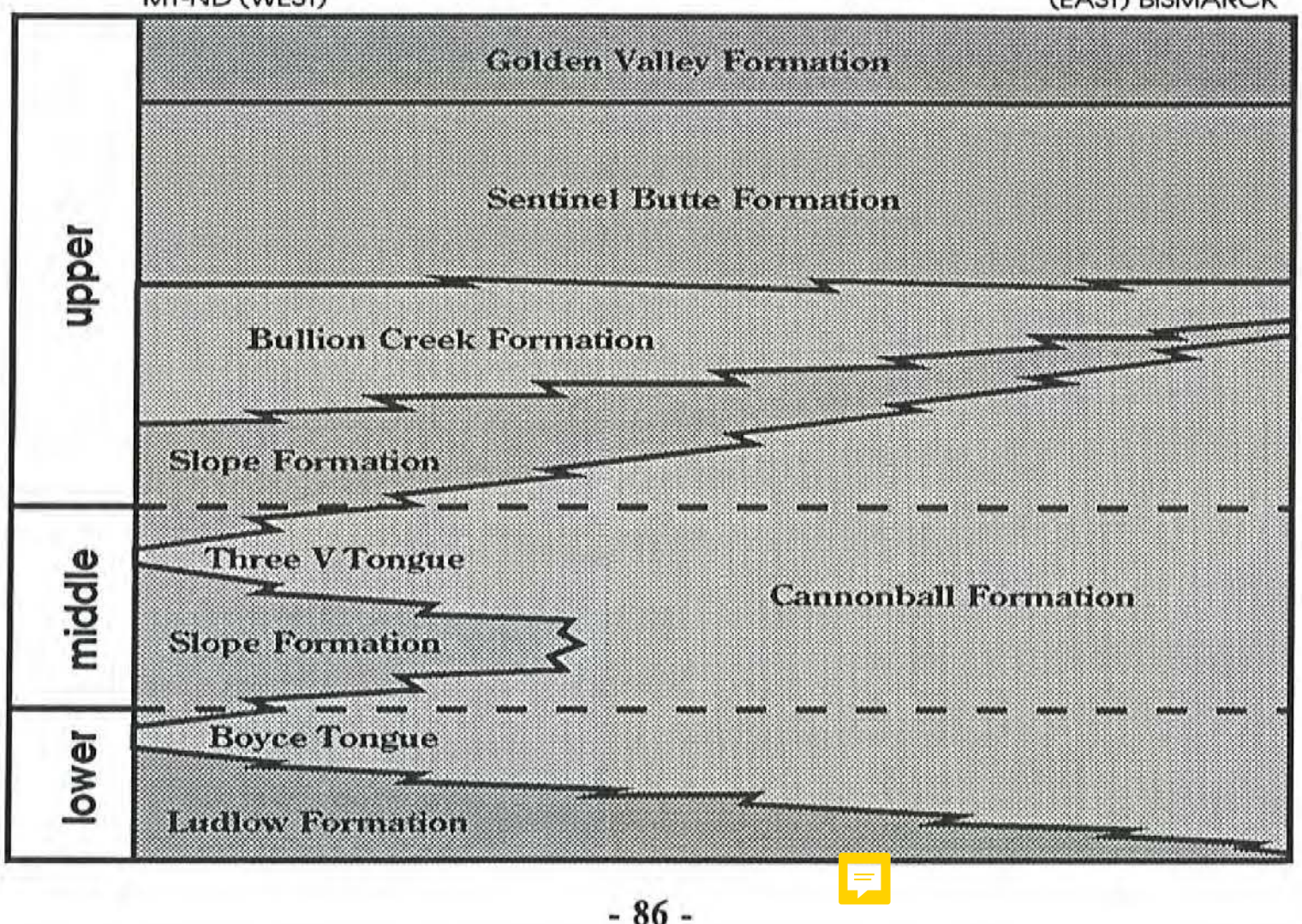




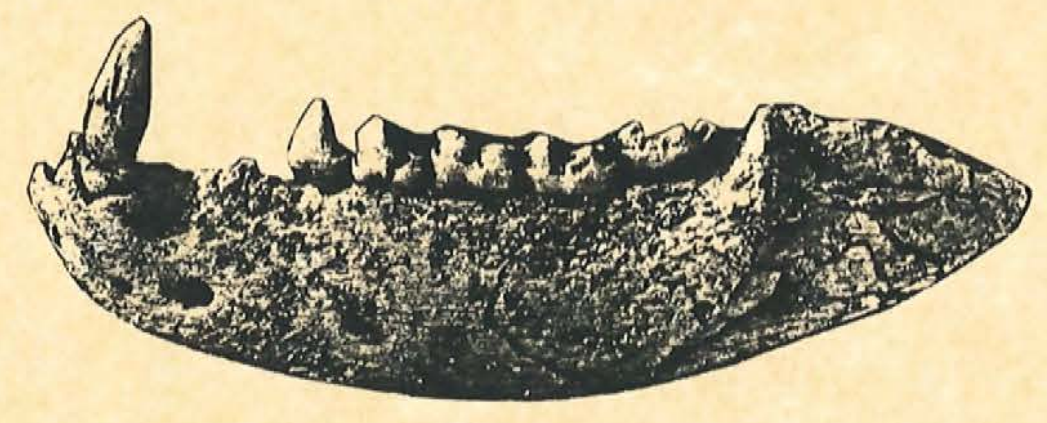

Lambertocyon eximius Gingerich

Paleocene condylarth from the Polecat Bench Formation.

Lateral view of right dentary $(8.2 \mathrm{~cm}$ in length) from Croc Tooth Quarry. Holotype collected by Russell Lambert from Big Horn County, Wyoming.

(P.D. Gingerich, 1979, Journal of Paleontology, v. 53, p. 526)

Reproduced by permission of the Paleontological Society. 
